\title{
To drain or not to drain : quantification of drainable intravascular venous volume during extracorporeal life support
}

Citation for published version (APA):

Simons, A. P. (2010). To drain or not to drain : quantification of drainable intravascular venous volume during extracorporeal life support. [Doctoral Thesis, Maastricht University]. Datawyse / Universitaire Pers Maastricht. https://doi.org/10.26481/dis.20100623as

Document status and date:

Published: 01/01/2010

DOI:

10.26481/dis.20100623as

Document Version:

Publisher's PDF, also known as Version of record

Please check the document version of this publication:

- A submitted manuscript is the version of the article upon submission and before peer-review. There can be important differences between the submitted version and the official published version of record.

People interested in the research are advised to contact the author for the final version of the publication, or visit the DOI to the publisher's website.

- The final author version and the galley proof are versions of the publication after peer review.

- The final published version features the final layout of the paper including the volume, issue and page numbers.

Link to publication

\footnotetext{
General rights rights.

- You may freely distribute the URL identifying the publication in the public portal. please follow below link for the End User Agreement:

www.umlib.nl/taverne-license

Take down policy

If you believe that this document breaches copyright please contact us at:

repository@maastrichtuniversity.nl

providing details and we will investigate your claim.
}

Copyright and moral rights for the publications made accessible in the public portal are retained by the authors and/or other copyright owners and it is a condition of accessing publications that users recognise and abide by the legal requirements associated with these

- Users may download and print one copy of any publication from the public portal for the purpose of private study or research.

- You may not further distribute the material or use it for any profit-making activity or commercial gain

If the publication is distributed under the terms of Article $25 \mathrm{fa}$ of the Dutch Copyright Act, indicated by the "Taverne" license above, 


\section{TO DRAIN OR NOT TO DRAIN}

Quantification of drainable intravascular venous volume during extracorporeal life support 
(c) Copyright AP Simons, Maastricht 2010

\section{ISBN 978-90-5278-948-4}

Printed by Datawyse I Universitaire Pers Maastricht

The author appreciates financial support for his dissertation.

Major financial support was granted by Maquet Cardiopulmonary AG. Additional financial support was given by Sorin Groep Nederland NV, Covidien Nederland BV and Terumo Europe NV. Financial support by Stichting Hartsvrienden RESCAR and the Netherlands Heart Foundation for the publication of this thesis is gratefully acknowledged. 


\title{
TO DRAIN OR NOT TO DRAIN Quantification of drainable intravascular venous volume during extracorporeal life support
}

\author{
PROEFSCHRIFT \\ Ter verkrijging van de graad van doctor \\ aan de Universiteit Maastricht, \\ op gezag van de Rector Magnificus, \\ Prof. mr. G.P.M.F. Mols, \\ volgens het besluit van het College van Decanen, \\ in het openbaar te verdedigen \\ op woensdag 23 juni 2010 om 14:00 uur \\ door
} Antoine P. Simons

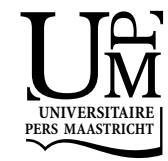




\section{Promotor}

Prof. dr. J.G. Maessen

\section{Copromotores}

Dr. ir. K.D. Reesink

Dr. P.W. Weerwind

\section{Beoordelingscommissie}

Prof. dr. W.H. Mess (voorzitter)

Prof. dr. M.P. van Dieijen-Visser

Prof. dr. M. van Kleef

Prof. dr. M.A. Mariani (Rijksuniversiteit Groningen) 
Promovendus?

Koffie leuten, nadenken, de hele dag

Schrijven doe je `s avonds, en 's morgens naar bed

En dan die volgende dag

Doe mij maar een koffie, gezellig, lekker

Lekker wakker worden

Goede middag

`s Middags was het weer laat geworden

Promovendus?

Koffie leuten, nadenken, de hele dag

Schrijven doe je 's avonds, en 's morgens naar bed

Overdag, dan moet je 'er zijn'

Overdag, dan denk je

Je drinkt een bakkie koffie

Koffie leuten, nadenken, schrijven

Promovendus, koffie leuten, goede nacht! 



\section{CONTENTS}

CHAPTER 1 General Introduction 9

CHAPTER 2 An in vitro and in vivo study of the detection and reversal of 21 venous collapse during extracorporeal life support

CHAPTER 3 Laboratory performance testing of venous cannulae during 33 inlet obstruction

CHAPTER 4 Dynamic filling index: A novel parameter to monitor circulatory filling during minimized extracorporeal bypass

CHAPTER 5 Reserve-driven flow control for extracorporeal life support: proof of principle

CHAPTER 6 Quantitative assessment of cardiac load-responsiveness during extracorporeal life support: case and rationale

CHAPTER 7 Letter to the Editor

CHAPTER 8 General Discussion

SUMMARY

SAMENVATTING

ZUSAMMENFASSUNG 

CHAPTER 1

GENERAL INTRODUCTION 
During the second half of the $20^{\text {th }}$ century, cardiopulmonary bypass using a heartlung machines evolved into a routine technique during heart and vascular surgery. Today, the benefits of extracorporeal circulation have been demonstrated in among others extracorporeal life support (ELS) during acute (postcardiotomy) heart-lung failure, high-risk coronary interventions, and respiratory failure [1-4].

\section{EXTRACORPOREAL LIFE SUPPORT}

In contrast to the conventional heart-lung machine for cardiopulmonary bypass, which is designed to take over cardiac and respiratory functions, the idea behind ELS is to assist the native circulation. With small modifications, the application of ELS has recently been expanded towards an alternative heart-lung machine in cardiothoracic surgery $[5,6]$. In that context, ELS has been reported to reduce preoperative hemodilution and transfusion requirements, and shows a lower incidence of postoperative complications [7-10]. Although the ideal use of ELS in terms of support would be to bridge a patient to recovery, ELS often acts as a bridge-to-decision or as a bridge to long-term mechanical support with a ventricular assist device [9, 11-13].

\section{The CirCUIT}

A typical ELS circuit basically consists of a venous and arterial cannula, a blood pump, and an oxygenator (Figure 1). The cannulae establish a direct connection between the ELS circuit and the patient's vascular system. Cannulation can either be central or peripheral, or a combination of both. With central cannulation, a configuration frequently used in open-heart surgery, the venous and arterial cannulae are inserted into the right atrium and the ascending aorta, respectively. With peripheral cannulation, a configuration often used in ELS, the venous cannula is inserted into a femoral or jugular vein, and the arterial cannula is located in the femoral or subclavian artery. 

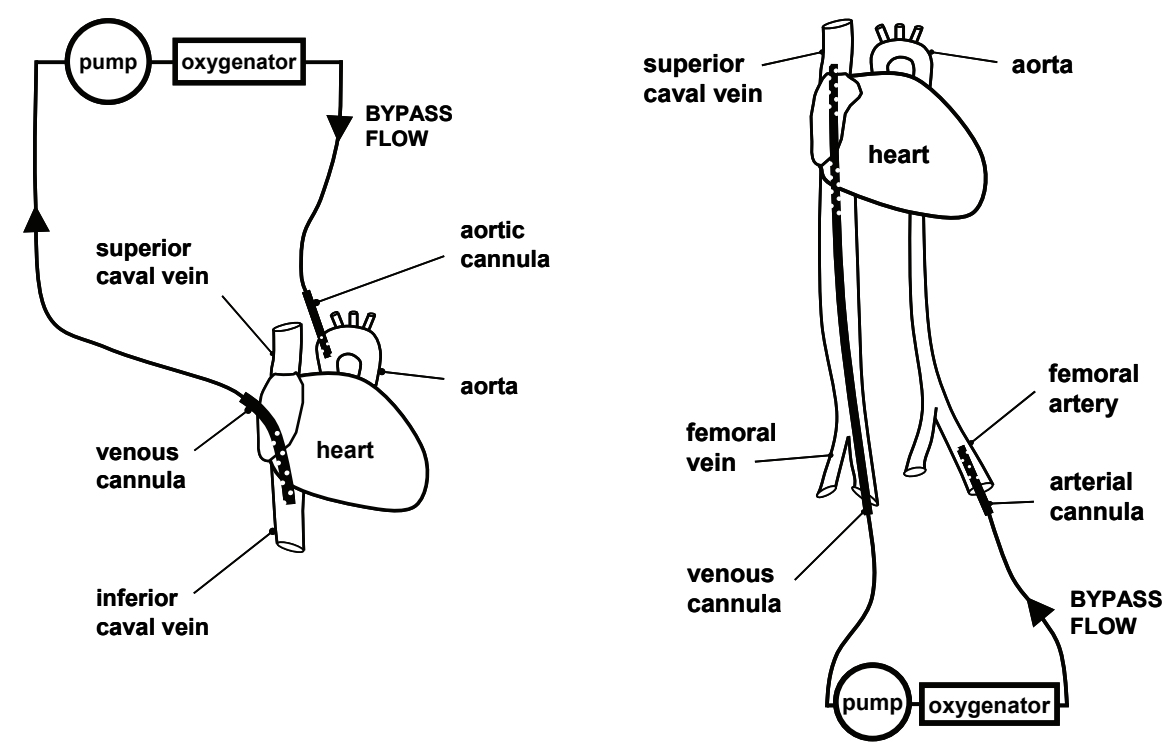

Figure 1 Veno-arterial extracorporeal life support via central (left) or peripheral cannulation (right).

The blood pump in the circuit enables cardiac unloading and provides body perfusion, whereas the oxygenator acts as an artificial lung. The oxygenator removes carbon dioxide and oxygenates the venous blood drawn by the pump. The ELS pump itself can either be a roller pump or a centrifugal pump, and pumps the blood back to the patient via the arterial cannula. Another ELS setup is the veno-venous configuration [14, 15]. This arrangement provides respiratory support only, as it does not augment perfusion of the body, nor does it unload the heart.

\section{Patient Filling Volume}

In contrast to the conventional circuits used for cardiopulmonary bypass, which feature reservoirs, ELS circuits do not contain reservoirs. As this cancels out the blood-activating direct blood-air contact, and drastically reduces the foreign surface and circuit priming, ELS circuits are categorized as minimized. Reservoirs in extracorporeal circuits, however, provide volume buffering capacity. With conventional circuits, perfusion during acutely impeded drainage can be maintained temporarily by draining volume from the reservoir. With ELS, however, the patient itself acts as reservoir. The buffering volume is given by the patient's own circulatory filling, which is the intravascular venous volume. Subsequently, with ELS, a sudden decrease in filling volume reduces the volume available for drainage, and can result in acutely impeded drainage and decreased bypass flow. Under these conditions of low filling, maintaining drainage and support flow can become challenging, as even 
short-lasting reductions in pump preload have been shown to result in persistent reduced circulatory support flow [16]. Therefore, operating a minimized circulatory support system demands a volume control strategy different from that employed with a conventional bypass system.

The influence of the patient circulatory volume on venous drainage, as well as possible methods to monitor and deal with low filling have been reported earlier [1, 16-23]. With the patient itself acting as venous reservoir, hemodynamic management is performed by vaso-active drugs [24-26]. Values for pump inlet pressure and arterial and central venous blood pressures are used to provide an indication of the venous volume status, and can give an indication of acute excessive drainage. However, absolute values for pressure can be misleading as they depend on pump and patient position (height difference) and the validity of the pressure measurement itself [27]. Furthermore, central venous pressure readings have been shown to be unreliable in reflecting patient filling [28]. Moreover, the read-out may be deceptive when pressure is measured close to the drainage cannula. In critical situations, the use of dynamic assessment methods has proven more informative than static measurement methods as the dynamic approach addresses system response [29-33]. Combined with ELS, such dynamic technique may provide an impression of the residual drainage capacity.

Additional to patient filling condition, drainage can also be affected by the design of the venous cannula. A smaller cannula inner diameter increases hydraulic resistance and requires decreased suction pressure to maintain drainage flow [21, 34-45]. During conditions of insufficient preload, the cannula tip may become occluded by aspiration of the vessel or atrial wall tissue, resulting in persistent decreased drainage $[16,21]$. In such conditions, the use of specially designed cannula tips may help to prevent inlet occlusion and maintain drainage when preload becomes critically low.

As mentioned before, with conventional extracorporeal bypass circuits as used during heart surgery, perfusion during impeded drainage can be maintained temporarily from the volume buffering capacities of the reservoir. With ELS, flow is directly dependent on drainage flow and reduced filling and cannula dislocation can lead to abrupt reductions of circuit flow. Although both cannula dislocation and patient filling condition can be monitored using transesophageal echocardiography during both surgical and non-surgical applications of ELS [46], a method not requiring additional tools or human resources would be preferable. In that context, a circulatory support system that senses and records the residual drainage capacity and adapts to the volume available for drainage could optimize drainage with challenging hemodynamics and reduce the incidence of hypoperfusion associated with low filling. 


\section{WEANING}

Weaning from extracorporeal assist and bypass devices remains a delicate procedure, and requires a strict observation of many different parameters [47]. Usually, supportive unloading is gradually reduced and combined with inotropic drug infusion if needed, while cardiac output, ventricular wall motion, and venous and arterial pressures are monitored continuously to assess hemodynamic stability [29]. Pressure readings, however, have been shown deceptive in many cases [28, 48, 49]. Alternatively, transesophageal echocardiography can be used to assess actual ventricular wall motion in response to progressive loading of the myocardium [50]. Transesophageal echocardiography is non-invasive, and has a low incidence of complications [51]. Nevertheless, the method requires the insertion of a measurement tool (the probe) which may lead to traumatic injury of the gastrointestinal tract [52]. Moreover, transesophageal echocardiography has proven limited in predicting cardiac functional reserve [53].

Literature describing the ELS weaning procedure itself is scarce and mainly qualitatively in nature $[15,54]$. Descriptions like 'with gradually reducing support' and 'reducing support down to tolerable hemodynamic levels' lack objective measures, and are frequently followed by statements that 'the patient could be successfully weaned', but leave 'successfully weaned' undefined [11, 15, 55-57]. Moreover, a weaning procedure can only be as good as the method allowing objective evaluation of data on cardiac load-responsiveness. Methods providing quantitative and reproducible data on cardiac function while on cardiac or circulatory support, however, are rare and are still in the preclinical phase of investigation. Nakata et al. showed a clear relationship between contractility of the heart and the stroke work of the assisting pump [58]. Hoshi et al showed a correlation between cardiac pump function and the eccentric impeller displacement of a magnetically levitated rotorary blood pump [59]. If clinically available, however, such methods broaden the spectrum of cardiac monitoring techniques, and might aid successful weaning patients from support. 


\section{FLOW CONDITIONS}

During the development of blood pumps for extracorporeal bypass, some designs focused on creating physiologic blood flow using innovative pump design and control [60-69]. Since its first application, many studies have been conducted to investigate the benefits of pulsatile perfusion. Some groups claim pulsatile flow to improve organ perfusion, per-operative hemodynamics, and patient outcome, and showed increased energy delivered to the vascular bed [70-74]. Others found conflicting and insufficient evidence for the benefits of pulsatile flow [75-78]. As a result, from its first application until today, "to pulse or not to pulse" remains a topic of controversial discussion [77, 79, 80].

Pulsatile flow generation by acceleration and deceleration of the centrifugal pump impeller requires pump preload to be sufficient for high peak flows. In extracorporeal bypass circuits in which the pump drains from a venous reservoir, this preload is most likely available instantaneously. With minimized bypass circuits lacking the buffering capacity, preload is limited to the intravascular volume which may prove insufficient during flow with a highly pulsatile character. Vessel wall aspiration and cannula inlet obstruction are likely to develop during pump systole as a result of excessive drainage, but during the subsequent pump diastole drainage is reduced to a minimum and drainage impediment will be resolved. Unfortunately, although the flow generated will have a pulsatile character, overall (total) flow will eventually prove insufficient. An alternative way of reducing the negative effects of high pulsatile flow generation in minimized circuits could be the use of non-drainage-increasing pulse generation by means of membrane pumps or enhanced rotor design [64, 65, 81-84] . 


\section{CONTENT OF ThIs Thesis}

The previous outline has illustrated patient filling to be a fundamental ingredient for successful operation of extracorporeal life support (ELS). This thesis focuses on the interaction of the support system and the patient's circulation with respect to patient filling, and in addition highlights hardware components used in extracorporeal circulation.

Chapter 2 presents a possible method to detect and reverse venous collapse resulting of low filling during extracorporeal life support, and uses in vitro and animal experimental data providing evidence for the rationale.

Chapter 3 illustrates the impact of tip design of different venous cannulae for central cannulation on drainage performance during obstruction of the inlet. A mock circulation was used to induce vessel collapse resulting of excessive drainage with insufficient filling.

Chapter 4 describes a clinical investigation of a measurement method to assess volume available for drainage during the application of minimized extracorporeal bypass systems. Luxation of the heart during coronary artery bypass surgery was used to change volume that can be potentially drained by the minimized extracorporeal circuit, and acted as a model for decreased circulatory filling. Data from transesophageal echocardiography were used to verify the impact of luxation on drainable volume.

Chapter 5 shows proof of principle for a reserve-driven pump control for extracorporeal life support, and presents animal experimental data in which the controller is tested during an acute condition of low filling.

Chapter 6 presents a case report in which a new approach for the quantitative assessment of cardiac load-responsiveness is introduced, and discusses its potential for assisting future weaning from extracorporeal life support.

Chapter 7 discusses a new pulsatile centrifugal blood pump described in literature and its potential for application in minimized bypass circuits as used in extracorporeal life support (letter in response to an original publication).

Chapter 8 offers a general discussion of the individual chapters and major findings, and provides a basis for future research on extracorporeal life support. 


\section{REFERENCES}

1. Bartlett RH, Roloff DW, Custer JR, Younger JG, Hirschl RB. Extracorporeal life support: the University of Michigan experience. Jama. 2000;283:904-8.

2. Fromes Y, Gaillard D, Ponzio O, Chauffert M, Gerhardt MF, Deleuze P, Bical OM. Reduction of the inflammatory response following coronary bypass grafting with total minimal extracorporeal circulation. Eur J Cardiothorac Surg. 2002;22:527-33.

3. Cooper DS, Jacobs JP, Moore L, Stock A, Gaynor JW, Chancy T, Parpard M, Griffin DA, Owens T, Checchia PA, Thiagarajan RR, Spray TL, Ravishankar C. Cardiac extracorporeal life support: state of the art in 2007. Cardiology in the young. 2007;17 Suppl 2:104-15.

4. Formica F, Avalli L, Martino A, Maggioni E, Muratore M, Ferro O, Pesenti A, Paolini G. Extracorporeal membrane oxygenation with a poly-methylpentene oxygenator (Quadrox D). The experience of a single Italian centre in adult patients with refractory cardiogenic shock. Asaio J. 2008;54:89-94.

5. Castiglioni A, Verzini A, Pappalardo F, Colangelo N, Torracca L, Zangrillo A, Alfieri O. Minimally invasive closed circuit versus standard extracorporeal circulation for aortic valve replacement. Ann Thorac Surg. 2007;83:586-91.

6. Immer FF, Ackermann A, Gygax E, Stalder M, Englberger L, Eckstein FS, Tevaearai HT, Schmidli J, Carrel TP. Minimal extracorporeal circulation is a promising technique for coronary artery bypass grafting. Ann Thorac Surg. 2007;84:1515-20; discussion 21.

7. Wiesenack C, Liebold A, Philipp A, Ritzka M, Koppenberg J, Birnbaum DE, Keyl C. Four years' experience with a miniaturized extracorporeal circulation system and its influence on clinical outcome. Artif Organs. 2004;28:1082-8.

8. van Boven WJ, Gerritsen WB, Waanders FG, Haas FJ, Aarts LP. Mini extracorporeal circuit for coronary artery bypass grafting: initial clinical and biochemical results: a comparison with conventional and off-pump coronary artery bypass grafts concerning global oxidative stress and alveolar function. Perfusion. 2004;19:239-46.

9. Abdel-Rahman U, Ozaslan F, Risteski PS, Martens S, Moritz A, Al Daraghmeh A, Keller H, Wimmer-Greinecker $\mathrm{G}$. Initial experience with a minimized extracorporeal bypass system: is there a clinical benefit? Ann Thorac Surg. 2005;80:238-43.

10. Gerritsen WB, van Boven WJ, Wesselink RM, Smelt M, Morshuis WJ, van Dongen HP, Haas FJ, Aarts LP. Significant reduction in blood loss in patients undergoing minimal extracorporeal circulation. Transfusion medicine (Oxford, England). 2006;16:329-34.

11. Pagani FD, Aaronson KD, Swaniker F, Bartlett RH. The use of extracorporeal life support in adult patients with primary cardiac failure as a bridge to implantable left ventricular assist device. Ann Thorac Surg. 2001;71:S77-81; discussion S2-5.

12. Oishi Y, Masuda M, Imasaka K, Morita S, Yasui H. Limitation of venoarterial bypass. Early predictor and optimal conversion. Asian cardiovascular \& thoracic annals. 2005;13:167-71.

13. Hoefer D, Ruttmann E, Poelzl G, Kilo J, Hoermann C, Margreiter R, Laufer G, Antretter H. Outcome evaluation of the bridge-to-bridge concept in patients with cardiogenic shock. Ann Thorac Surg. 2006;82:28-33.

14. Hermans G, Meersseman W, Wilmer A, Meyns B, Bobbaers H. Extracorporeal membrane oxygenation: experience in an adult medical ICU. The Thoracic and cardiovascular surgeon. 2007;55:223-8.

15. Marasco SF, Lukas G, McDonald M, McMillan J, Ihle B. Review of ECMO (extra corporeal membrane oxygenation) support in critically ill adult patients. Heart, lung \& circulation. 2008;17 Suppl 4:S41-7. 
16. Reesink KD, Dekker A, Van der Nagel T, Beghi C, Leonardi F, Botti P, De Cicco G, Lorusso R, Van der Veen FH, Maessen JG. Suction due to left ventricular assist: implications for device control and management. Artif Organs. 2007;31:542-9.

17. Atkinson JB, Emerson P, Wheaton R, Bowman CM. A simplified method for autoregulation of blood flow in the extracorporeal membrane oxygenation circuit. Journal of pediatric surgery. 1989;24:251-2.

18. Setz K, Kesser K, Kopotic RJ, Cornish JD. Comparison of a new venous control device with a bladder box system for use in ECMO. ASAIO J. 1992;38:835-40.

19. Montoya JP, Merz SI, Bartlett RH. Significant safety advantages gained with an improved pressure-regulated blood pump. J Extra Corpor Technol. 1996;28:71-8.

20. Pedersen TH, Videm V, Svennevig JL, Karlsen H, Ostbakk RW, Jensen O, Mollnes TE. Extracorporeal membrane oxygenation using a centrifugal pump and a servo regulator to prevent negative inlet pressure. Ann Thorac Surg. 1997;63:1333-9.

21. Kurusz M, Deyo DJ, Sholar AD, Tao W, Zwischenberger JB. Laboratory testing of femoral venous cannulae: effect of size, position and negative pressure on flow. Perfusion. 1999;14:37987.

22. Tamari Y, Lee-Sensiba K, King S, Hall MH. An improved bladder for pump control during ECMO procedures. J Extra Corpor Technol. 1999;31:84-90.

23. Misgeld BJ, Werner J, Hexamer M. Robust and self-tuning blood flow control during extracorporeal circulation in the presence of system parameter uncertainties. Medical \& biological engineering \& computing. 2005;43:589-98.

24. Hoeksel SA, Blom JA, Jansen JR, Maessen JG, Schreuder JJ. Automated infusion of vasoactive and inotropic drugs to control arterial and pulmonary pressures during cardiac surgery. Critical care medicine. 1999;27:2792-8.

25. Tschaut R. Extrakorporale Zirkulation in Theorie und Praxis. 1st ed. Berlin, Duesseldorf, Leipzig, Riga, Scottsdale, Vienna, Zagreb: Pabst 1999.

26. Lauterbach G. Handbuch der Kardiotechnik. 4rd ed. Munnich, Jena: Urban \& Fischer 2002.

27. Magder S. Central venous pressure monitoring. Current opinion in critical care. 2006;12:219-27.

28. Androne AS, Hryniewicz K, Hudaihed A, Mancini D, Lamanca J, Katz SD. Relation of unrecognized hypervolemia in chronic heart failure to clinical status, hemodynamics, and patient outcomes. The American journal of cardiology. 2004;93:1254-9.

29. Lichtwarck-Aschoff M, Beale R, Pfeiffer UJ. Central venous pressure, pulmonary artery occlusion pressure, intrathoracic blood volume, and right ventricular end-diastolic volume as indicators of cardiac preload. Journal of critical care. 1996;11:180-8.

30. Pinsky MR, Payen D. Functional hemodynamic monitoring. Critical care (London, England). 2005;9:566-72.

31. Pinsky MR, Teboul JL. Assessment of indices of preload and volume responsiveness. Current opinion in critical care. 2005;11:235-9.

32. Hadian M, Pinsky MR. Functional hemodynamic monitoring. Current opinion in critical care. 2007;13:318-23.

33. Maizel J, Airapetian N, Lorne E, Tribouilloy C, Massy Z, Slama M. Diagnosis of central hypovolemia by using passive leg raising. Intensive Care Med. 2007.

34. Arom KV, Ellestad C, Grover FL, Trinkle JK. Objective evaluation of the efficacy of various venous cannulas. J Thorac Cardiovasc Surg. 1981;81:464-9.

35. Bennett EV, Jr., Fewel JG, Ybarra J, Grover FL, Trinkle JK. Comparison of flow differences among venous cannulas. Ann Thorac Surg. 1983;36:59-65. 
36. Delius RE, Montoya JP, Merz SI, McKenzie J, Snedecor S, Bove EL, Bartlett RH. New method for describing the performance of cardiac surgery cannulas. Ann Thorac Surg. 1992;53:278-81.

37. Grigioni M, Daniele C, Morbiducci U, D'Avenio G, G. Di Benedetto, Gaudio CD, Barbaro V. Computational model of the fluid dynamics of a cannula inserted in a vessel: incidence of the presence of side holes in blood flow. J Biomech. 2002;35:1599-612.

38. Humphries K, Sistino JJ. Laboratory evaluation of the pressure flow characteristics of venous cannulas during vacuum-assisted venous drainage. J Extra Corpor technol. 2002;34:111-4.

39. Jegger D, Mueller X, Mucciolo G, Mucciolo A, Boone Y, Seigneul I, Horisberger J, von Segesser LK. A new expandable cannula to increase venous return during peripheral access cardiopulmonary bypass surgery. Int J Artif Organs. 2002;25:136-40.

40. Jegger D, Tevaearai HT, Mueller XM, Pierrel N, Horisberger J, von Segesser LK. Flow dynamic comparison of peripheral venous cannulas used with centrifugal pump assistance in vitro. Artif Organs. 2002;26:390-2.

41. Jegger D, Corno AF, Mucciolo A, Mucciolo G, Boone Y, Horisberger J, Seigneul I, Jachertz M, von Segesser LK. A prototype paediatric venous cannula with shape change in situ. Perfusion. 2003;18:61-5.

42. Vandenberghe S, Nishida T, Segers P, Meyns B, Verdonck P. The Impact of Pump Speed and Inlet Cannulation Site on Left Ventricular Unloading with a Rotary Blood Pump. Artificial Organs. 2004;28:660-7.

43. von Segesser LK, Jegger D, Mucciolo G, Tozzi P, Mucciolo A, Delay D, Mallabiabarrena I, Horisberger J. The Smartcanula: a new tool for remote access perfusion in limited access cardiac surgery. Heart Surg Forum. 2005;8:E241-5.

44. Jegger D, Chassot PG, Bernath MA, Horisberger J, Gersbach P, Tozzi P, Delay D, von Segesser LK. A novel technique using echocardiography to evaluate venous cannula performance perioperatively in CPB cardiac surgery. Eur J Cardiothorac Surg. 2006;29:525-9.

45. Park JY, Park CY, Min BG. A numerical study on the effect of side hole number and arrangement in venous cannulae. J Biomech. 2007;40:1153-7.

46. Jakob H, Sturer A, Palzer B, Maass D, Iversen S, Oelert H. [Extracorporeal circulatory assistance with centrifugal pumps in postcardiotomy low-output syndrome]. Helvetica chirurgica acta. 1990;57:365-72.

47. Vakamudi M. Weaning from cardiopulmonary bypass: problems and remedies. Annals of cardiac anaesthesia. 2004;7:178-85.

48. Gelman S. Venous function and central venous pressure: a physiologic story. Anesthesiology. 2008;108:735-48.

49. Kumar A, Anel R, Bunnell E, Habet K, Zanotti S, Marshall S, Neumann A, Ali A, Cheang M, Kavinsky C, Parrillo JE. Pulmonary artery occlusion pressure and central venous pressure fail to predict ventricular filling volume, cardiac performance, or the response to volume infusion in normal subjects. Critical care medicine. 2004;32:691-9.

50. Salem R, Vallee F, Rusca M, Mebazaa A. Hemodynamic monitoring by echocardiography in the ICU: the role of the new echo techniques. Current opinion in critical care. 2008;14:561-8.

51. Daniel WG, Erbel R, Kasper W, Visser CA, Engberding R, Sutherland GR, Grube E, Hanrath P, Maisch B, Dennig K. Safety of transesophageal echocardiography. A multicenter survey of 10,419 examinations. Circulation. 1991;83:817-21.

52. Colreavy FB, Donovan K, Lee KY, Weekes J. Transesophageal echocardiography in critically ill patients. Critical care medicine. 2002;30:989-96.

53. Michard F, Teboul JL. Predicting fluid responsiveness in ICU patients: a critical analysis of the evidence. Chest. 2002;121:2000-8. 
54. Stulak JM, Dearani JA, Burkhart HM, Barnes RD, Scott PD, Schears GJ. ECMO Cannulation Controversies and Complications. Seminars in cardiothoracic and vascular anesthesia. 2009.

55. Gajarski RJ, Mosca RS, Ohye RG, Bove EL, Crowley DC, Custer JR, Moler FW, Valentini A, Kulik TJ. Use of extracorporeal life support as a bridge to pediatric cardiac transplantation. J Heart Lung Transplant. 2003;22:28-34.

56. Agati S, Mignosa C, Ciccarello G, Dario S, Undar A. Pulsatile ECMO in neonates and infants: first European clinical experience with a new device. Asaio J. 2005;51:508-12.

57. Huang SC, Chen YS, Chi NH, Hsu J, Wang CH, Yu HY, Chou NK, Ko WJ, Wang SS, Lin FY. Out-of-center extracorporeal membrane oxygenation for adult cardiogenic shock patients. Artif Organs. 2006;30:24-8.

58. Nakata KI, Shiono M, Akiyama K, Orime Y, Saito A, Tutomu H, Negishi N, Sezai Y, Sankai Y. The estimation of cardiac function from the rotary blood pump. Artif Organs. 2001;25:709-12.

59. Hoshi H, Asama J, Hara C, Hijikata W, Shinshi T, Shimokohbe A, Takatani S. Detection of left ventricle function from a magnetically levitated impeller behavior. Artif Organs. 2006;30:37783.

60. Nakayama K, Tamiya T, Yamamoto K, Izumi T, Akimoto S, Hashizume S, Iimori T, Odaka M, Yazawa C. High-Amplitude Pulsatile Pump in Extracorporeal Circulation with Particular Reference to Hemodynamics. Surgery. 1963;54:798-809.

61. Eguchi S, Asano K. A new pulsatile pump controlled by a roller system. Surgery. 1968;63:490-5.

62. Verbiski N, Beckett F, Jerabek O, Kolff WJ. Pulsatile flow blood pump based on the principle of the Wankel engine. Preliminary report. J Thorac Cardiovasc Surg. 1969;57:753-6.

63. Sanderson JM, Morton PG, Tolloczko TS, Vennart T, Wright G. The Morton-Keele pump--a hydraulically activated pulsatile pump for use in extracorporeal circulation. Medical \& biological engineering. 1973;11:182-90.

64. Bregman D, Bowman FO, Jr., Parodi EN, Haubert SM, Edie RN, Spotnitz HM, Reemtsma K, Malm JR. An improved method of myocardial protection with pulsation during cardiopulmonary bypass. Circulation. 1977;56:II157-60.

65. Kaplitt MJ, Tamari Y, Frantz SL, Vagnini FJ, Beil AR, Jr. Clinical experience with TamariKaplitt pulsator. New device to create pulsatile flow or counterpulsation during open-heart surgery [proceedings]. New York state journal of medicine. 1978;78:1090-4.

66. Taylor KM, Bain WH, Maxted KJ, Hutton MM, McNab WY, Caves PK. Comparative studies of pulsatile and nonpulsatile flow during cardiopulmonary bypass. I. Pulsatile system employed and its hematologic effects. J Thorac Cardiovasc Surg. 1978;75:569-73.

67. Rottenberg D, Sondak E, Rahat S, Borman JB, Dviri E, Uretzky G. Early experience with a true pulsatile pump for heart surgery. Perfusion. 1995;10:171-5.

68. Nishida H, Uesugi H, Nishinaka T, Uwabe K, Aomi S, Endo M, Koyanagi H, Oshiyama H, Nogawa A, Akutsu T. Clinical evaluation of pulsatile flow mode of Terumo Capiox centrifugal pump. Artif Organs. 1997;21:816-21.

69. Ressler N, Rider AR, Kunselman AR, Richardson JS, Dasse KA, Wang S, Undar A. A hemodynamic evaluation of the Levitronix Pedivas centrifugal pump and Jostra H1-20 roller pump under pulsatile and nonpulsatile perfusion in an infant CPB model. Asaio J. 2009;55:106-10.

70. Taylor KM, Bain WH, Davidson KG, Turner MA. Comparative clinical study of pulsatile and non-pulsatile perfusion in 350 consecutive patients. Thorax. 1982;37:324-30.

71. Thompson T, Minami K, Dramburg W, Vyska K, Koerfer R. The influence of pulsatile and nonpulsatile extracorporeal circulation on fluid retention following coronary artery bypass grafting. Perfusion. 1992;7:201-11. 
72. Undar A, Frazier OH, Fraser CD, Jr. Defining pulsatile perfusion: quantification in terms of energy equivalent pressure. Artif Organs. 1999;23:712-6.

73. Ressler N, Rider AR, Kunselman AR, Richardson JS, Dasse KA, Wang S, Undar A. Quantification of perfusion modes in terms of surplus hemodynamic energy levels in a simulated pediatric CPB model. Asaio J. 2006;52:712-7.

74. Alkan T, Akcevin A, Undar A, Turkoglu H, Paker T, Aytac A. Benefits of pulsatile perfusion on vital organ recovery during and after pediatric open heart surgery. Asaio J. 2007;53:651-4.

75. Hickey PR, Buckley MJ, Philbin DM. Pulsatile and nonpulsatile cardiopulmonary bypass: review of a counterproductive controversy. Ann Thorac Surg. 1983;36:720-37.

76. Mulholland JW, Shelton JC, Luo XY. Blood flow and damage by the roller pumps during cardiopul monary bypass. J Fluid Struct. 2005;20:129-40.

77. Alghamdi AA, Latter DA. Pulsatile versus nonpulsatile cardiopulmonary bypass flow: an evidence-based approach. Journal of cardiac surgery. 2006;21:347-54.

78. Murkin JM. Pulsatile versus nonpulsatile perfusion revisited. Journal of cardiac surgery. 2006;21:355-6.

79. Mavroudis C. To pulse or not to pulse. Ann Thorac Surg. 1978;25:259-71.

80. Hornick P, Taylor K. Pulsatile and nonpulsatile perfusion: the continuing controversy. Journal of cardiothoracic and vascular anesthesia. 1997;11:310-5.

81. Tamari Y, Frantz SL, Vagnini FJ, Beil AR, Jr., Degnan TJ, Seidman S, Garfinkle TJ, Newman JC, Kaplitt MJ. Experimental evaluation and clinical application of intraoperative counterpulsation without balloon pumping. The Journal of cardiovascular surgery. 1976;17:398-407.

82. Monties JR, Mesana T, Havlik P, Trinkl J, Demunck JL, Candelon B. Another way of pumping blood with a rotary but noncentrifugal pump for an artificial heart. ASAIO Trans. 1990;36:M258-60.

83. Herreros J, Berjano EJ, Sales-Nebot L, Mas P, Calvo I, Mastrobuoni S, Merce S. A new method of providing pulsatile flow in a centrifugal pump: assessment of pulsatility using a mock circulatory system. Artif Organs. 2008;32:490-4.

84. Jaggy C, Lachat M, Leskosek B, Zund G, Turina M. Affinity pump system: a new peristaltic blood pump for cardiopulmonary bypass. Perfusion. 2000;15:77-83. 


\section{CHAPTER 2}

\section{AN IN VITRO AND IN VIVO STUDY OF THE DETECTION AND REVERSAL OF VENOUS COLLAPSE DURING EXTRACORPOREAL LIFE SUPPORT}

Presented in part at the 14th Congress of the International Society of Rotary Blood Pumps, held August 31-September 2, 2006 in Leuven, Belgium.

\section{Published as:}

Simons AP, Reesink KD, Molegraaf GV, van der Nagel T, de Jong MMJ, Severdija EE, van der Veen FH, de Jong DS, Maessen JG. An in vitro and in vivo study of the detection and reversal of venous collapse during extracorporeal life support. Artif Organs. 2007;31:152-9. 


\section{Abstract}

The objective of this study was to investigate venous collapse (VC) related to venous drainage during the use of an extracorporeal life support circuit. A mock circulation was built containing a centrifugal pump and a collapsible vena cava model to simulate VC under controlled conditions. Animal experiments were performed for in vivo verification. Changing pump speed had a different impact on flow during a collapsed and a distended caval vein in both models. Flow measurement in combination with pump speed interventions allows for the detection and quantitative assessment of the degree of VC. Additionally, it was verified that a quick reversal of a VC situation could be achieved by a 2-step pump speed intervention, which also proved to be more effective than a straightforward decrease in pump speed. 


\section{INTRODUCTION}

The growing field of indications to install extracorporeal life support (ELS) [1-5] has introduced the need for guidelines to choose an optimal pump flow rate. As current ELS systems become smaller with low priming volume and small or absent reservoirs, instantaneous pump flow adaptations are more critical. Whereas a low flow rate sometimes can be recognized by, for example, a low arterial pressure and decreased blood gas values, a high flow rate may result in a too high negative pressure at the pump inlet, which may be related to a venous collapse (VC) and a drop in pumping efficiency [6-10]. Apart from the hemodynamic consequences, blood damage and tissue aspiration have been reported [11-15]. Prevention is difficult, because VC situations often develop gradually and will therefore not always be noticed in time. Detection of VC can be performed adequately using Doppler imaging techniques [16] or by monitoring pump parameters [17-22]. However, such techniques may prove too complex or are still under development. Simple manual pump speed adjustments and simultaneous observation of flow changes by perfusionists may indicate an acute VC, however, a quantitative evaluation and a method for early detection of VC have not been reported earlier. The use of a roller pump in combination with a bladder bag inserted into the venous line, prevents excessive drainage by an immediate pump shut down [23, 24]. However, the device does not solve the VC and requires immediate attendance of a perfusionist or ELS-trained nurse. To allow the number of indications for ELS to grow, pump speed adjustments should be automated to improve safety.

We investigated the potential of pump speed manipulations during centrifugal pump-based life support for the early detection of VC and the quantitative influence on hemodynamics for a proper VC reversal. For this purpose, VC was simulated in a mock circulation and in an animal protocol.

\section{MAterial And Methods}

\section{Mock circulation}

Figure 1 shows a scheme of the water-filled mock circulation. It consists of a venous reservoir with a collapsible vena cava model, an ELS system, and an arterial reservoir. The venous filling pressure and extravascular pressure can be set by adjusting the height of the corresponding reservoirs. A rubber tube clamped into a transparent plastic housing functions as a collapsible vena cava model. The arterial reservoir is closed to the atmosphere and functions as a vascular compliance, which can be set by adjusting the entrapped air volume. An adjustable tube clamp mimics the pe- 
ripheral vascular resistance. A rising tube placed behind the tube clamp simulates the capillary perfusion pressure and is set to $+15 \mathrm{mmHg}$.

An adult 30-inch 23 Fr femoral venous cannula (Medtronic Inc., Minneapolis, MN, USA) was used for drainage and was connected to a centrifugal pump (CAPIOX system with SP pump head and PS-101 pump controller, speed range: 0-3,000 rpm, Terumo Corporation, Tokyo, Japan). The oxygenator used was a Polystan Safe Maxi Adult Oxygenator (Maquet Cardiopulmonary AG, Hirrlingen, Germany).

Flow was measured with a tubing flow sensor, having a read-out accuracy of $\pm 7 \%$ (Transonic Systems Inc., Ithaca, NY, USA). Pump inlet pressure was measured approximately $30 \mathrm{~cm}$ in front of the pump with a pressure transducer having a read-out accuracy of $\pm 3 \%$ (Baxter International Inc., Deerfield, IL, USA). Data acquisition was performed with IDEEQ software (Instrument Development Engineering \& Evaluation, Maastricht University, Maastricht, The Netherlands).

During an immediate pump shutdown a short lasting backflow through the pump (shunting) is provided by the compliance of the arterial reservoir. However, this arterial buffer does not induce a long-lasting backflow at low pump speeds or during a pump stop. It should only provide for a short back-flow and a shortly remaining arterial pressure that will distend the collapsed vena cava model from the arterial side. Like in the clinical application in patients with a low cardiac output syndrome, the arterial pressure and the flow will decrease when the assisting pump is turned down.

The relationship between pump flow and pump speed was determined at different venous filling pressures and extravascular pressures. The venous filling pressure ranged from 0 to $+20 \mathrm{mmHg}$ in steps of $4 \mathrm{mmHg}$. The extravascular pressure was varied in steps of $2 \mathrm{mmHg}$ from $-4 \mathrm{mmHg}$ to $+4 \mathrm{mmHg}$. The transmural pressure was calculated by subtracting the extravascular pressure from the venous filling pressure. This resulted in fifteen transmural pressure values, ranging from -4 to $+24 \mathrm{mmHg}$. The arterial pressure was maintained at a level of $80-90 \mathrm{mmHg}$ with each setting by adjusting the peripheral resistance clamp. For each transmural pressure, pump speed was varied from $500 \mathrm{rpm}$ up to 3,000 rpm and back to $500 \mathrm{rpm}$ in steps of $500 \mathrm{rpm}$. Changing pump speed took about 3 seconds. After every change in pump speed the system was given 1 minute to settle.

For each preload setting in the mock circulation, the differential flow-speed ratio ( $\Delta$ flow $/ \Delta$ speed) was determined by linear approximation as follows: $\Delta$ flow $/ \Delta$ speed $=$ flow (3000)-flow $(1500)] /(3000-1500) \mathrm{ml} /$ rotation . 


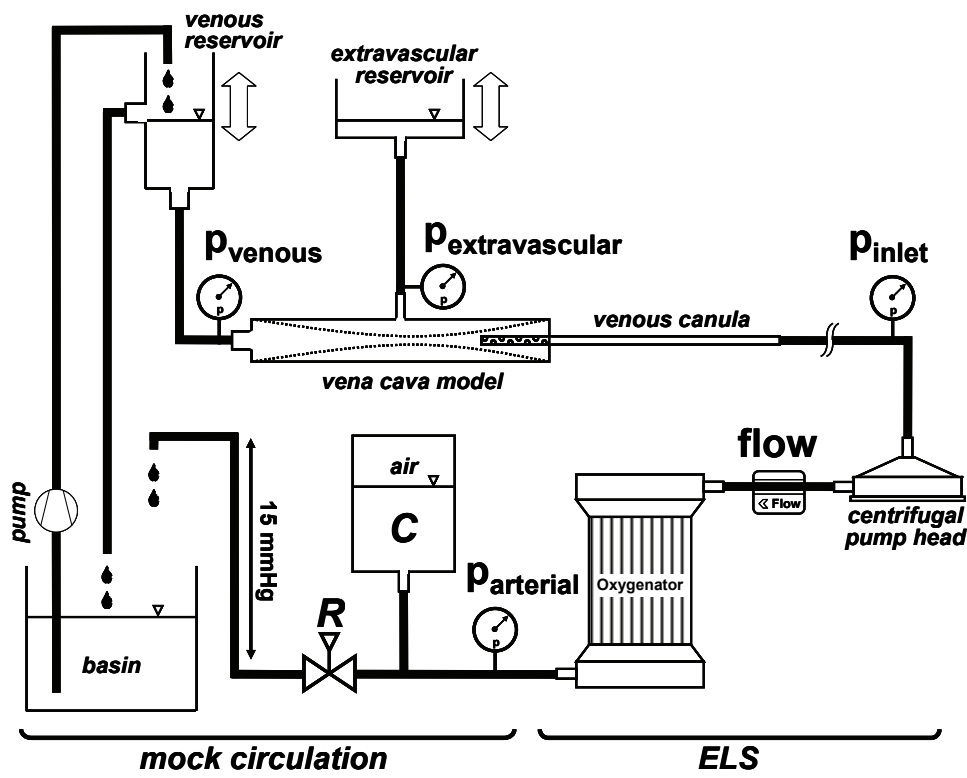

Figure 1 Mock circulation for simulating venous collapse under controlled conditions.

\section{Differential flow-speed ratio for collapse detection}

\section{In vitro}

In the mock circulation the influence of pump speed manipulations was measured by performing a reduction of pump speed by $150 \mathrm{rpm}$ during a visually verifiable non-collapsed situation and a visually verifiable VC situation. For the calculation of the differential flow-speed, flow was measured before and after the pump speed manipulation.

\section{In vivo}

In a related animal protocol using the same ELS circuit, the collapse detection method was evaluated. Seven pigs underwent midsternotomy with standard central cannulation. The influence of pump speed manipulations on flow was measured at two different filling pressure situations. The adequate filling pressure situation was given by a full bypass situation, providing a flow of $4-51 / \mathrm{min}$ and an arterial pressure of $80-100 \mathrm{mmHg}$. The low filling pressure was induced by clamping the vena cava inferior. The flow was recorded before and after a pump speed reduction of $100 \mathrm{rpm}$. Subsequently, the differential flow-speed ratio was calculated.

All animals received humane care in compliance with the "Guide for the Care and Use of Laboratory Animals" (NIH publication 86-23, 1985 revision; National Institute of Health, USA). 


\section{Collapse reversal}

The preceding paragraph discussed pump speed interventions for the calculation of differential flow-speed ratios and detection of VC. This paragraph deals with pump speed interventions for the resolution of VC.

The effectiveness of two strategies for the reversal of a VC situation was examined. The first strategy employed a straightforward reduction in pump speed, whereas the second approach consisted of a 2-step pump speed intervention used by perfusionists and experienced intensive care unit (ICU) nurses.

For both tests, the initial values for pump speed and flow were 1,800 rpm and $4.2 \mathrm{l} / \mathrm{min}$, respectively. Flow was measured continuously during the interventions and monitored for a period of 5 more minutes after. During the straightforward speed reduction, the pump speed was abruptly reduced to 1,600 rpm. For the 2-step intervention, the pump speed was abruptly reduced to $900 \mathrm{rpm}$ (50\%) and kept at this level for 10 seconds. Then, the speed was increased to $1,600 \mathrm{rpm}$ at a rate of $70 \mathrm{pm} / \mathrm{s}$.

\section{Results}

\section{Mock circulation}

For the different transmural pressures used, the flow values ranged from $0.11 / \mathrm{min}$ at $500 \mathrm{rpm}$ up to $10.5 \mathrm{l} / \mathrm{min}$ at 3,000 rpm. Pump inlet pressure ranged from ca. $+10 \mathrm{mmHg}$ at $500 \mathrm{rpm}$ down to a maximum negative pressure of ca. $-420 \mathrm{mmHg}$ at $3,000 \mathrm{rpm}$.

Figure 2 left shows the relationship between the volemic situation of the mock circulation and its responsiveness to pump speed changes. This curve displays the differential flow-speed ratio as a function of the transmural pressure. The read-out accuracy of the flow sensor was taken into account when calculating the differential values. To show the influence of these read-out errors in the curves, the measuring errors are indicated by the dashed lines in Figure 2 left.

The calculated differential flow-speed ratio for flow ranged from $0.2 \mathrm{ml} /$ rotation during a VC situation at a low transmural pressure, up to $4.4 \mathrm{ml} /$ rotation during a distended vein condition at a high transmural pressure (Figure 2 left).

\section{Differential flow-speed ratio for collapse detection}

Table 1 shows the in vitro results of a pump speed intervention for VC detection during distended and VC conditions. In case of a non-collapsed situation, a flow change of $-0.5 \mathrm{l} / \mathrm{min}$ was measured. In a collapsed situation, flow did not change. In a non-collapsed situation the in vitro differential flow-speed ratio calculated amounted to $3.3 \mathrm{ml} /$ rotation and in a collapsed situation it was 0 . 
Table 1 Detection of VC by pump speed interventions in the mock circulation.

\begin{tabular}{lllll}
\hline Situation & $\begin{array}{l}\text { Pump inlet } \\
(\mathbf{m m H g})\end{array}$ & $\begin{array}{l}\text { Pump speed } \\
(\mathbf{r p m})\end{array}$ & $\begin{array}{l}\text { Flow } \\
(\mathbf{l} / \mathbf{m i n})\end{array}$ & $\begin{array}{l}\Delta \text { flow/ } \mathbf{\Delta} \text { speed } \\
(\mathbf{m l} / \text { rotation) }\end{array}$ \\
\hline No collapse & -89 & 1,800 & 5.7 & \\
& -72 & 1,650 & 5.2 & 3.3 \\
Collapse & -116 & 1,800 & 4.5 & \\
& -78 & 1,650 & 4.5 & 0 \\
\hline
\end{tabular}

The differential flow-speed ratios obtained from the mock circulation and the animal protocol are put together in table 2.

Table 2 Differential flow-speed index (in $\mathrm{ml} /$ rotation) obtained in vitro and in pigs.

\begin{tabular}{lll}
\hline Situation & \multicolumn{2}{l}{$\Delta$ flow/ $\Delta$ speed (ml/rotation) } \\
in vitro & in vivo, $\mathbf{n}=\mathbf{7}$ \\
\hline No collapse & 3.3 & $3.7 \pm 0.9$ \\
Collapse & 0 & $0.5 \pm 0.6$ \\
\hline
\end{tabular}

Values are mean \pm standard deviation

\section{Collapse reversal}

The effect of both types of speed interventions in the mock circulation during a visually verified VC on flow is shown in Figure 2 right. The straightforward speed down intervention from $1,800 \mathrm{rpm}$ down to $1,600 \mathrm{rpm}$ resulted in a reduced flow after 25 seconds, while VC persisted. The 1st step of the 2-step speed intervention resulted in a flow of approximately $2.5 \mathrm{l} / \mathrm{min}$. The subsequent linear increase in pump speed to $1,600 \mathrm{rpm}$ at a rate of $70 \mathrm{rpm} / \mathrm{s}$ resulted in a resolution of the collapsed condition and an increased flow of $4.7 \mathrm{l} / \mathrm{min}$.
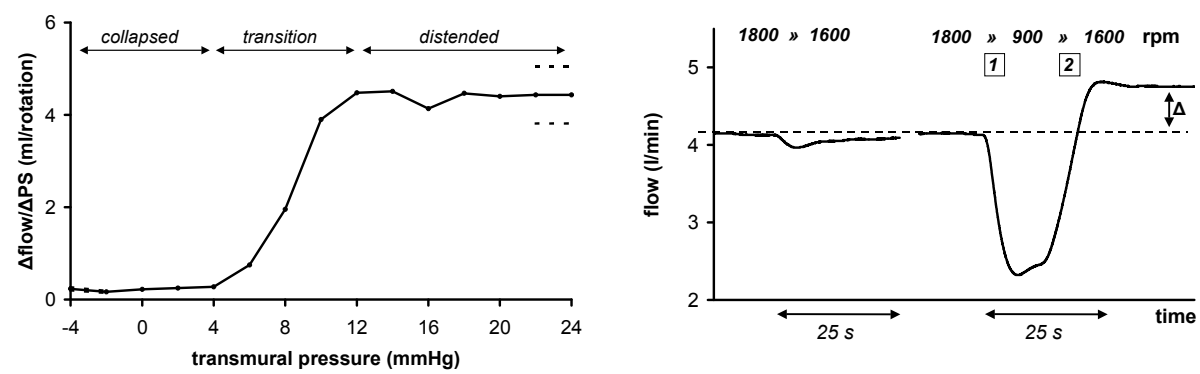

Figure 2 (Left) Differential flow-speed ratio as a function of transmural pressure. Regions for collapse, transition, and distension of the vena cava model are indicated. The dashed lines represent the estimated measuring errors corresponding with the errors on the flow and pressure reading. (Right) The effect on flow using a 1-step pump speed intervention (leftt) and a 2-step pump speed intervention (right). 


\section{DISCUSSION}

In this study, we hypothesized that the use of pump speed interventions enables early quantitative detection and reversal of venous collapse (VC). Therefore, we investigated the relationship between venous drainage and VC with an ELS system implemented in a mock circulation and in vivo.

\section{Differential flow-speed ratio for collapse detection}

Our results indicate that the use of pump speed interventions have potential to aid the detection and reversal of VC. The described method of collapse detection enabled distinction between a non-collapsed and a VC situation in the mock circulation and in vivo (Figure 2 left and table 2), and allowed for a quantitative estimate of the degree of VC.

The monitoring of pump inlet pressure is commonly used to monitor the venous drainage. The in vitro values for pump inlet pressure at 1,650 rpm, however, do not significantly distinguish between a distended situation or a VC (table 1). In addition, pump inlet pressure depends on the pump height with respect to heart level, and can be altered during patient transport or patient manipulation. The absolute value of pump inlet pressure is therefore unsuited to discriminate between a venous drainage-return match or mismatch. The calculated value for differential flow-speed ratios can be regarded as a sensitivity that indicates the pumping efficiency or ease of drainage. A decreasing ease of drainage may indicate the development of a VC situation. Therefore, combining pump inlet pressure with flow measurement and the subsequent analysis of differential flow-speed ratios may improve the monitoring of venous drainage.

If a VC develops gradually, periodic pump speed interventions can be used to monitor this development, and to quantify the degree of VC. Further empirical studies are required to identify clinically suitable cut-off values. The method may then specifically aid the detection of venous drainage impediment, for example, VC or cannula dislocation.

Sensor baseline signal drift will not affect the sensitivity calculation because the detection measurement consists of a differential measurement, which is independent of a baseline drift and is performed over a relatively small time interval. Regarding the invasiveness of the measurement method, pressure is measured by an intravascular catheter or by a pressure sensor inserted in the venous path of the circulation. Flow measurement can be performed ultrasonically by a tubing flow sensor and therefore without blood contact. Furthermore, indirect flow measurement using no pressure or flow sensors has been reported [25]. 


\section{Collapse reversal}

The flow curves in Figure 2 right showed that the 2-step pump speed intervention reversed the VC and subsequently induced an increased flow at a lower pump speed. The simple straightforward pump speed reduction did not have such a positive effect; it resulted in neither a resolution of the VC nor an increase of flow.

During a VC, the drainage is outrunning the venous return and causes the right atrium and/or caval veins to collapse. A 1-step pump speed intervention results in a pump speed with a lower drainage. This reduced drainage level, however, can still be higher than the venous return available, if the pump speed reduction has been insufficient. Because of the collapsed vein, the increased flow resistance, and the consequent flow blockage, the collapsed situation remains. During a 2-step intervention, pump speed is reduced drastically to a drainage level being less than the venous backflow. This enables the vein to distend and the flow resistance to decrease. A subsequent increase in pump speed, up to a speed level below the initial pump speed increases the flow.

An intervention that uses a complete pump shut down also resulted in an immediate reversal of VC within less than $5 \mathrm{~s}$. This provides evidence for the existence of a relationship between the intervention time and the amount of change of pump speed. However, more experiments will be necessary to show the relation between the amount of a pump speed reduction and the time it lasts.

\section{Study limitations}

This study did not include a dislocation of the venous cannula or a kinking of the tube. A dislocation may induce wall aspiration and a subsequent flow reduction. A reduction of flow will also be noticed during a kinking of the tube, and a calculation and analysis of the differential flow-speed ratio will indicate an impeded venous drainage. Relocating the cannula or solving the kinking can be sufficient to regain flow and increase the flow-speed ratio.

The use of another type of centrifugal pump having different speed-flow characteristics, will alter differential flow-speed ratios. Due to a change of the ratios the simple discrimination between a VC and a distended situation might become more obvious and so would positively affect the (early) detection of a VC.

The mock circulation offers a preload section that is decoupled from the afterload section. Nevertheless, the circulation allowed for the investigation about drainage and VC in ELS applications. The setup simulated a full-bypass. ELS applications, however, are also used for partial bypass applications. For simulating a partial bypass ELS application in vitro, the setup would require an additional pulsatile pump simulating the beating heart. This pump then should be placed in between the venous and arterial reservoir. 


\section{CONCLUSION}

Pump speed interventions allow the evaluation of the relationship between VC and venous drainage in centrifugal pump-based ELS systems. In this in vitro and in vivo study, pump speed manipulations enabled numerical determination of pumping efficiency during active venous drainage. This can be very helpful and may have great potential in the development of an automatic monitoring and control of the venous return in relation to early detection, reversal or even prevention of VC. This approach may improve the safety of minimized ELS systems and increase the number of indications for ELS support by reducing the need for continuous operator-dependent control.

\section{ACKNOWLEDGMENT}

The authors would like to thank Terumo Europe N.V., Cardiovascular Division (Leuven, Belgium) for materials and technical support. 


\section{REFERENCES}

1. Whyte RI, Deeb GM, McCurry KR, Anderson HL, 3rd, Bolling SF, Bartlett RH. Extracorporeal life support after heart or lung transplantation. Ann Thorac Surg. 1994;58:754-8; discussion 8-9.

2. Kolla S, Lee WA, Hirschl RB, Bartlett RH. Extracorporeal life support for cardiovascular support in adults. ASAIO J. 1996;42:M809-19.

3. Bartlett RH, Roloff DW, Custer JR, Younger JG, Hirschl RB. Extracorporeal life support: the University of Michigan experience. Jama. 2000;283:904-8.

4. Pagani FD, Aaronson KD, Swaniker F, Bartlett RH. The use of extracorporeal life support in adult patients with primary cardiac failure as a bridge to implantable left ventricular assist device. Ann Thorac Surg. 2001;71:S77-81; discussion S2-5.

5. Gajarski RJ, Mosca RS, Ohye RG, Bove EL, Crowley DC, Custer JR, Moler FW, Valentini A, Kulik TJ. Use of extracorporeal life support as a bridge to pediatric cardiac transplantation. J Heart Lung Transplant. 2003;22:28-34.

6. Amoore JN, Santamore WP. Venous collapse and the respiratory variability in systemic venous return. Cardiovasc Res. 1994;28:472-9.

7. Toomasian JM, McCarthy JP. Total extrathoracic cardiopulmonary support with kinetic assisted venous drainage: experience in 50 patients. Perfusion. 1998;13:137-43.

8. Hiroura M, Furusawa T, Amino M, Moriya T, Goto H, Fukaya Y, Amano J. Clinical experience of a vacuum-assisted nonroller extracorporeal circulation system. J Extra Corpor Technol. 2000;32:148-51.

9. Jegger D, Tevaearai HT, Mueller XM, Horisberger J, von Segesser LK. Limitations using the vacuum-assist venous drainage technique during cardiopulmonary bypass procedures. J Extra Corpor Technol. 2003;35:207-11.

10. Reesink KD, Sauren LD, Dekker AL, Severdija E, van der Nagel T, Geskes GG, van der Veen FH, Maessen JG. Synchronously counterpulsating extracorporeal life support enhances myocardial working conditions regardless of systemic perfusion pressure. Eur J Cardiothorac Surg. 2005;28:790-6.

11. Pedersen TH, Videm V, Svennevig JL, Karlsen H, Ostbakk RW, Jensen O, Mollnes TE. Extracorporeal membrane oxygenation using a centrifugal pump and a servo regulator to prevent negative inlet pressure. Ann Thorac Surg. 1997;63:1333-9.

12. Lapietra A, Grossi EA, Pua BB, Esposito RA, Galloway AC, Derivaux CC, Glassman LR, Culliford AT, Ribakove GH, Colvin SB. Assisted venous drainage presents the risk of undetected air microembolism. J Thorac Cardiovasc Surg. 2000;120:856-62.

13. Cirri S, Negri L, Babbini M, Latis G, Khlat B, Tarelli G, Panisi P, Mazzaro E, Bellisario A, Borghetti B, Bordignon F, Ferrara M, Pavan H, Meco M. Haemolysis due to active venous drainage during cardiopulmonary bypass: comparison of two different techniques. Perfusion. 2001;16:313-8.

14. Ni Y, Leskosek B, Shi L, Chen Y, Qian L, Li R, Tu Z, Segesser LK. Optimization of venous return tubing diameter for cardiopulmonary bypass. European Journal of Cardio-Thoracic Surgery. 2001;20:614-20.

15. Banbury MK, White JA, Blackstone EH, Cosgrove DM, 3rd. Vacuum-assisted venous return reduces blood usage. J Thorac Cardiovasc Surg. 2003;126:680-7.

16. Ishizaki $Y$, Fukuoka H, Ishizaki T, Kino M, Higashino H, Ueda N, Fujii $Y$, Kobayashi $Y$. Measurement of inferior vena cava diameter for evaluation of venous return in subjects on day 10 of a bed-rest experiment. J Appl Physiol. 2004;96:2179-86. 
17. Trinkl J, Havlik P, Mesana T, Mitsui N, Morita S, Demunck JL, Tourres JL, Monties JR. Control of a rotary pulsatile cardiac assist pump driven by an electric motor without a pressure sensor to avoid collapse of the pump inlet. ASAIO J. 1993;39:M237-41.

18. Ohuchi K, Kikugawa D, Takahashi K, Uemura M, Nakamura M, Murakami T, Sakamoto T, Takatani S. Control strategy for rotary blood pumps. Artif Organs. 2001;25:366-70.

19. Bullister E, Reich S, Sluetz J. Physiologic control algorithms for rotary blood pumps using pressure sensor input. Artif Organs. 2002;26:931-8.

20. Vollkron M, Schima H, Huber L, Benkowski R, Morello G, Wieselthaler G. Development of a suction detection system for axial blood pumps. Artif Organs. 2004;28:709-16.

21. Vollkron M, Schima H, Huber L, Benkowski R, Morello G, Wieselthaler G. Development of a reliable automatic speed control system for rotary blood pumps. J Heart Lung Transplant. 2005;24:1878-85.

22. Holzer S, Scherer R, Schmidt C, Schwendenwein I, Wieselthaler G, Noisser R, Schima H. A clinical monitoring system for centrifugal blood pumps. Artif Organs. 1995;19:708-12.

23. Setz K, Kesser K, Kopotic RJ, Cornish JD. Comparison of a new venous control device with a bladder box system for use in ECMO. ASAIO J. 1992;38:835-40.

24. Tamari Y, Lee-Sensiba K, King S, Hall MH. An improved bladder for pump control during ECMO procedures. J Extra Corpor Technol. 1999;31:84-90.

25. Hoshi H, Shinshi T, Takatani S. Third-generation blood pumps with mechanical noncontact magnetic bearings. Artif Organs. 2006;30:324-38. 


\section{CHAPTER 3}

\section{LABORATORY PERFORMANCE TESTING OF VENOUS CANNULAE DURING INLET OBSTRUCTION}

Presented in part at the $12^{\text {th }}$ European Congress on Extracorporeal Circulation Technology, held June 6-9, 2007 in Kiev, Ukraine.

Published as:

Simons AP, Ganushchak Y, Wortel P, van der Nagel T, van der Veen FH, de Jong DS, Maessen JG. Laboratory performance testing of venous cannulae during inlet obstruction. Artif Organs. 2008;32:566-71. 


\section{Abstract}

Venous cannulae undergo continuous improvements to achieve better and safer venous drainage. Several cannula tests have been reported, though cannula performance during inlet obstruction has never been a test criterion. In this study, five different cannulae for proximal venous drainage were tested in a mock circulation that enabled measurement of hydraulic conductance after inlet obstruction by vessel collapse. Values for hydraulic conductance ranged from $1.11 \cdot 10^{-2} 1 \cdot \mathrm{min}^{-1} \cdot \mathrm{mmHg}^{-1}$ for a Thin-Flex Single Stage Venous Cannula with an open-end lighthouse tip to $1.55 \cdot 10^{-2} 1 \cdot \mathrm{min}^{-1} \cdot \mathrm{mmHg}^{-1}$ for a DLP VAD Venous Cannula featuring a swirled tip profile, showing a difference that amounts to nearly $40 \%$ of the lowest conductance value. Excessive venous drainage results in potentially dangerous high-negative venous line pressures independent of cannula design. Cannula tip design featuring swirled and grooved tip structures increases drainage capacity and enhances cannula performance during inlet obstruction. 


\section{INTRODUCTION}

Techniques using new extracorporeal circuits have been developed to decrease priming volume, reduce blood loss, and improve clinical outcome [1-4]. As minimized extracorporeal circulatory circuits lack a buffering venous reservoir, the pump drains directly from the venous system. As a result, the control of blood flow at low venous filling pressures (i.e., low central venous pressure) becomes more challenging. Too high pump speeds induce cannula inlet obstruction by aspiration of the vessel wall. Subsequently, drainage and circulatory support decline and venous congestion develops [5-7]. Strong aspiration must be avoided as it causes hemolysis [8], and degassing due to strong depression should not remain unconsidered $[9,10]$. Moreover, minimized systems may pass on gaseous embolisms directly to the patient's circulation when additional safety tools are not considered for use of [11-14].

Cannulae featuring expandable stents and a high number of inlet holes should allow for a higher drainage flow at lower trans-cannula pressures [15-18]. Cannula manufacturers supply graphs that show the relationship between cannula flow and the trans-cannula pressure gradient. Also, tests of venous cannulae have been reported [5, 19-23], but the in vitro models were not collapsible or lacked a twosided venous inflow to simulate the vv. cavae. In addition, cannula performance during inlet obstruction was not a test criterion.

In this study, we compared five venous cannulae with different inlet designs in a closed mock circulation regarding their performance during inlet obstruction. Obstruction was induced by overdrainage and subsequent venous collapse. Cannula performance was determined by measuring the hydraulic conductance during inlet obstruction.

\section{Materials And Methods}

\section{Cannulae}

The following five cannulae were tested:

A. DLP VAD Venous Cannula (36-Fr DLP-VAD-95036, Medtronic Inc., Minneapolis, MN, USA). The tip allows drainage from the cross-shaped tip inlet and from the grooved side holes;

B. Thin-Flex Single Stage Venous Cannula (RMI 38-Fr TF-038L, Edwards Lifesciences LLC, Irvine, CA, USA). The open-end lighthouse tip features one main entrance hole and several tapered side holes;

C. Dual Stage Venous Drainage Cannula (RMI 28x38-Fr TR-2838-L, Edwards Lifesciences LLC). The closed-end lighthouse tip features side holes but lacks a 
main entrance hole. The second drainage site facilitates several embedded premolded side holes;

D. MC2X Three Stage Venous Cannula (29x37-Fr MC2X 91437C, Medtronic Inc.). The open-end lighthouse tip features one main entrance hole with side holes. Also, the second drainage site features side holes. The third stage consists of a protruding round-cage structure with side holes;

E. Venous Cannula Opti-Flow (29-Fr V182-29 Opti-Flow, Stöckert, Sorin Group Italia S.r.l., Mirandola, Italy). It features one main entrance hole. The drainage area has a swirled grooved surface profile that houses drainage holes and has a length of approximately $13 \mathrm{~cm}$.

\section{Mock circulation}

A water filled closed mock circulation was assembled (Figure 1 left) consisting of a venous and an arterial reservoir, both closed to the atmosphere, a collapsible model with the caval veins and a centrifugal pump (Rotaflow 32 with Rotaflow drive unit and operator console, Maquet Cardiopulmonary AG, Hirrlingen, Germany). The collapsible model consisted of a flabby $19 \mathrm{~mm}$ inner diameter rubber hose (het Rubberhuis, Maastricht, The Netherlands) having a length of $35 \mathrm{~cm}$ and a wall thickness of $1 \mathrm{~mm}$. The Young's modulus of this natural product ranges from 1 to $10 \mathrm{~N} \cdot \mathrm{mm}^{-2}$. Cannulation was performed through a punctured 4-mm side hole.

Flow was measured using the flow probe that was integrated in the drive unit of the pump head. Pressures were measured by pressure transducers (Baxter International, Inc., Deerfield, IL, USA) in the venous and arterial reservoir and at the inlet and outlet of the pump. Pressure transducers were zero-calibrated to the atmosphere. Data acquisition was performed with IDEEQ software (Instrument Development Engineering \& Evaluation, Maastricht University, Maastricht, The Netherlands).

The pressure sensors, reservoirs, pump, and collapsible model were installed at one level to reduce influences of hydrostatic pressures. A tube clamp simulated the cumulative hydraulic resistance of the oxygenator, the arterial tubing and the arterial cannula, and is indicated by " $R$ " in Figure 1 right. Another adjustable flow clamp simulated the peripheral vascular resistance.

The initial system pressure (filling pressure) was set to $25 \mathrm{mmHg}$. Increasing pump speed increased flow and arterial pressure but diminished venous pressure (Figure 1 right) [24]. As venous pressure approached $0 \mathrm{mmHg}$, the vessel model collapsed. Subsequently, the collapse around a cannula was identical and reproducible. Increasing the peripheral resistance induced a venous pressure of $0 \mathrm{mmHg}$ at a lower flow. 

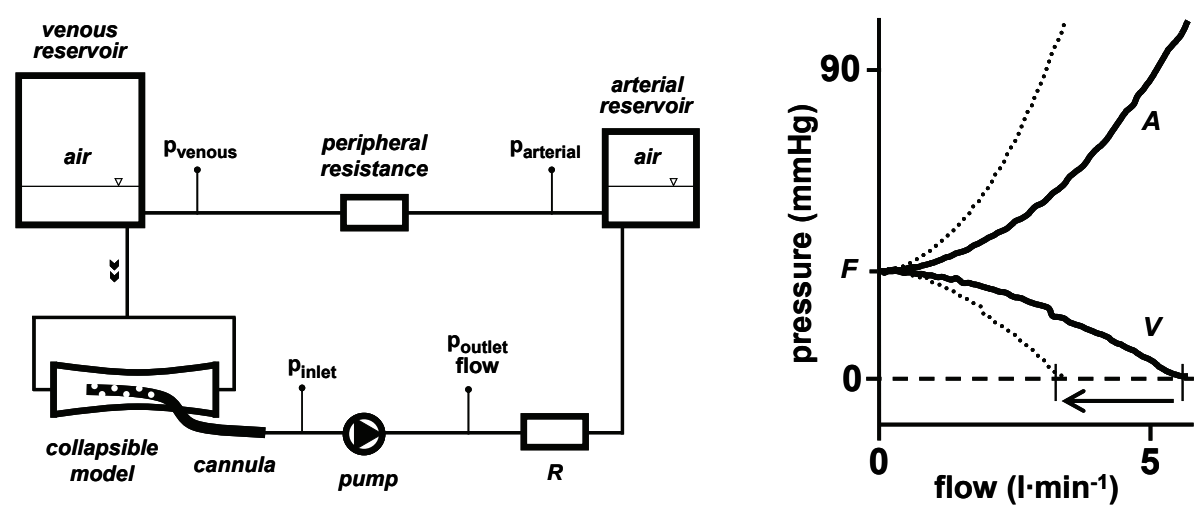

Figure 1 (Left) Mock circulation with collapsible vessel model to test venous cannulae. (Right) The relationship between flow, arterial pressure $[\mathrm{A}]$ and venous pressure $[\mathrm{V}]$ in the mock circulation. $\mathrm{F}=$ filling pressure. As venous pressure approaches $0 \mathrm{mmHg}$, a vessel collapse develops and obstructs the cannula inlet. The arrow indicates the decrease of the flow rate at which the vessel collapses when the peripheral resistance is increased (dotted line).

\section{Test protocol}

After mounting a cannula into the collapsible model, the circuit was primed. The pump speed was increased to 5,000 rpm in steps of $50 \mathrm{rpm} / \mathrm{s}$, providing a quasistatic approach. After each step, flow and pump inlet pressure were registered. At $5,000 \mathrm{rpm}$ speed was maintained for $10 \mathrm{~s}$, resulting in 10 additional samples for flow and pump inlet pressure. The procedure of speeding up and maintaining pump speed was repeated five times for each cannula, resulting in 50 values for flow and pump inlet pressure at 5,000 rpm in total for each cannula. Hydraulic conductance was determined by calculating flow/I pump inlet pressurel.

Flow and pressure values were statistically compared in SPSS 15 (SPSS, Inc., Chicago, IL, USA) by a one-way Bonferroni-corrected ANOVA test. Differences between values are assumed to be significant when $\mathrm{p}<0.05$.

\section{RESULTS}

Mean curves for the flows and pump inlet pressures for each cannula are shown in Figure 2 left. Up to $55 \mathrm{~s}$, inter-cannula flow differences amount to less than $0.21 \cdot \mathrm{min}^{-1}$ and can be explained by minor differences in cannula flow resistance. The curves for pump inlet pressure show an incisory between 55 and $60 \mathrm{~s}$, resulting from the development of a one-side collapse of the vein model. Between 60 and $70 \mathrm{~s}$, collapse development continued and drainage resistance increased. The increase of pump speed compensated for this increased drainage resistance, as flow was not affected. Pump inlet pressure continued dropping. After $70 \mathrm{~s}$, all cannulae had reached the critical flow at which complete collapse had developed. 
The Thin-Flex Single Stage Venous Cannula (Edwards Lifesciences LLC) enabled the lowest peak flow. This indicates that while the model started collapsing, this cannula got obstructed immediately. In contrary, the Venous Cannula OptiFlow (Stöckert, Sorin Group Italia S.r.l.) enabled the highest peak flow. This indicates that an obstruction of the drainage holes, this cannula needed some additional seconds. This additional time frame allowed for a longer, and, therefore, higher drainage flow. As the increase of pump speed continued, inlet obstruction enforced. Flow rates and pump inlet pressures for all cannulae declined.

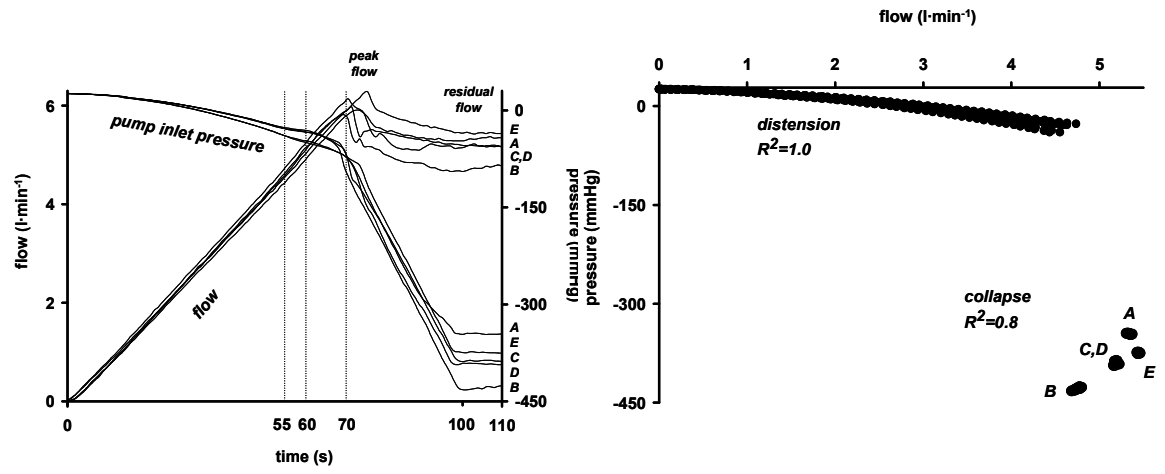

Figure 2 (Left) Curves showing an overview of flow and pump inlet pressure for the five different cannulae while increasing pump speed. At $55 \mathrm{~s}$, the model starts collapsing, resulting in a one-side collapse at $60 \mathrm{~s}$. At $70 \mathrm{~s}$, the collapse is fully developed. (Right) Correlation between flow and pump inlet pressure. At sufficient preload, cannula performance is predictable, whereas cannula performance during collapse is affected by tip design, and represented by the location of its point cloud.

Table 1 gives an overview of the residual flows, pump inlet pressures, and hydraulic conductance at 5,000 rpm. Except for flow values of the dual-stage and threestage cannulae $(\mathrm{p}=1.000)$, those of the other cannulae showed a significant difference $(\mathrm{p}=0.016)$. The strongest cannula aspiration was induced with the Thin-Flex Single Stage Venous Cannula (Edwards Lifesciences LLC), which induced the lowest residual flow $\left(4.7 \pm 0.01 \cdot \mathrm{min}^{-1}\right)$ and highest negative pump inlet pressure $(-429 \pm 2 \mathrm{mmHg})$. The DLP VAD Venous Cannula (Medtronic, Inc.) produced the least negative inlet pressure $(-346 \pm 10 \mathrm{mmHg})$, but the Venous Cannula Opti-Flow (Stöckert, Sorin Group Italia S.r.l.) enabled the highest residual flow level $\left(5.4 \pm 0.01 \cdot \mathrm{min}^{-1}\right)$.

Figure 2 right shows the correlation between flow and pump inlet pressure before (time $<55 \mathrm{~s}$ ) and after cannula tip obstruction due to vessel collapse (time $>100 \mathrm{~s}$ ). Before obstruction, speeding up the pump increased flow and decreased pump inlet pressure. During obstruction, a higher residual flow involved a higher inlet pressure. A point cloud characterizes the hydraulic conductance of a cannula after venous collapse with subsequent inlet obstruction. 
Table 1 Residual flow rates, corresponding pump inlet pressures, and calculated hydraulic conductances.

\begin{tabular}{|c|c|c|c|}
\hline Cannula & $\begin{array}{l}\text { flow } \\
\left(1 \cdot \mathrm{min}^{-1}\right)\end{array}$ & $\begin{array}{l}\text { p-inlet pressure } \\
(\mathrm{mmHg})\end{array}$ & $\begin{array}{l}\text { hydraulic conductance } \\
\left(10^{-2} 1 \cdot \mathrm{min}^{-1} \cdot \mathrm{mmHg}^{-1}\right)\end{array}$ \\
\hline A) DLP VAD & $5.3 \pm 0.1$ & $-346 \pm 10$ & 1.55 \\
\hline B) Single Stage & $4.7 \pm 0.0$ & $-429 \pm 2$ & 1.11 \\
\hline C) Dual Stage & $5.2 \pm 0.0$ & $-387 \pm 16$ & 1.34 \\
\hline D) MC2X Three Stage & $5.2 \pm 0.0$ & $-392 \pm 2$ & 1.32 \\
\hline E) Opti-Flow & $5.4 \pm 0.0$ & $-374 \pm 2$ & 1.45 \\
\hline
\end{tabular}

Values are mean \pm standard deviation, $\mathrm{n}=5$.

\section{DISCUSSION}

The aim of this in vitro study was to compare different cannulae for proximal venous drainage. In induced situations of cannula inlet obstruction, measuring flow rate and pump inlet pressure provides information about the cannula's hydraulic conductance and drainage performance.

Our data confirm previous findings of Kurusz et al., stating that cannula design has no demonstrable effect on flow, and that there is a tendency for flow to plateau or cease while drainage is increased [5]. However, their study did not specifically investigate cannula performance during inlet obstruction. Our results show that tip design significantly affected drainage after cannula obstruction (Figure 2 right and Table 1). Cannula performance before inlet obstruction and with sufficient preload was predictable $\left(\mathrm{R}^{2}=1.0\right)$, whereas performance was less predictable during collapse $\left(R^{2}=0.8\right)$, and is represented by the location of a point cloud in Figure 2 right. Performance is higher if a point cloud is located more to the upper right, as it indicates a higher flow with less depression at the pump inlet. From a clinical point of view, however, inter-cannulae differences remained small.

From our results and observations during the repeated measurements, we categorize venous drainage into three zones:

ZONE 1: the venous pressure is sufficient to distend the collapsible model (venous pressure $>0 \mathrm{mmHg}$ ). Increasing pump speed increases flow. The slope of the speedflow curve provides information about the cannula's hydraulic resistance. In the mock circulation, the condition above could be found at time $<55 \mathrm{~s}$.

ZONE 2: the drainage flow reaches a level at which venous pressure approaches $0 \mathrm{mmHg}$, and the vein model starts collapsing. A comparable relationship has been published by Amoore et al. [25], who showed the relationship between venous collapse and respiratory variability. The number of occluded inlet holes increases, but maintaining pump speed induces a periodic releasing and aspirating of the 
cannula. In clinical application, this is referred to as 'fluttering' of the venous line. The venous pressure fluctuates around $0 \mathrm{mmHg}$ (venous pressure $= \pm 0 \mathrm{mmHg}$ ). In the mock circulation the time frame that corresponded to this zone is indicated by $55 \mathrm{~s}<$ time $<60 \mathrm{~s}$.

ZONE 3: the drainage site is completely collapsed. The venous pressure in the vessels distal from the collapsed drainage sited has increased (venous pressure $>0 \mathrm{mmHg}$ ) [7]. The collapse and cannula inlet obstruction induce a reduced flow and extreme depression at the pump inlet. In the mock circulation, this condition of complete collapse could be seen at time $>70 \mathrm{~s}$.

The high residual flow rates offered by the DLP VAD Venous Cannula (Medtronic, Inc.) and Venous Cannula Opti-Flow (Stökcert, Sorin Group Italia S.r.1) (5.3 and $5.41 \cdot \mathrm{min}^{-1}$ ) show the impact of a grooved tip structure. The drainage entrances of the Thin-Flex Single Stage Venous Cannula (Edwards Lifesciences LLC) are situated on the outside of the cannula. There are no structures available to prevent a block of the drainage holes by aspirated tissue. Occlusion will be more profound with this type of tip design, indicated by the lowest residual drainage flow $\left(4.71 \cdot \mathrm{min}^{-1}\right)$ and highest negative pump inlet pressure $(-429 \mathrm{mmHg})$.

These results indicate that drainage would benefit from cannulae that are able to improve the handling of drainage during low venous filling. Although lacking a buffering reservoir, in combination with a high performance cannula a minimized system is able to deal with critical low filling conditions, and can provide a more stable flow and less fluctuating pressures.

The best performing cannula, however, can only function properly if placed correctly. A high-performance cannulae that has been poorly placed and/or is too small in size may not differ from a cannula featuring a simple design that has been placed in an optimal position. To maintain optimal performance, the location of a cannula should be verified frequently, e.g., during luxation of the heart. Also, a cannula too large in size cannot perform optimally, as the cannula is forced to the vessel wall and becomes obstructed in advance.

When surgical techniques require the atrium to be opened, the vv. cavae are cannulated separately by two single-stage lighthouse cannulae. To reduce wall aspiration, the use of two swirled-tip cannulae could be a viable alternative.

Most of the cannulae compared in this study feature a punched open-end lighthouse tip, whereas the lighthouse tip of the Dual Stage Venous Drainage Cannula (Edwards Lifesciences LLC) has a closed-end design. In a future study, it would be interesting to quantify the effect of lighthouse tip designs on drainage capacity, especially during inlet obstruction.

Additional accessories that enable a safer drainage are intelligent pump control systems that use software algorithms to improve the drainage. They can complete 
the impact of innovative cannula designs on flow in critical situations. To prove this hypothesis future experiments will be necessary.

\section{Study limitations}

This study included only one specimen of each cannula. However, it introduced a testing method for consistent measurement of cannula performance during obstruction, indicated by the relatively small standard deviations on the measured residual flow and corresponding pressure values.

The DLP VAD Venous Cannula (Medtronic, Inc.), the MC2X Three Stage Venous Cannula (Medtronic, Inc.) and the Venous Cannula Opti-Flow (Stöckert, Sorin Group Italia S.r.l.) are available only in the sizes used here. The Thin-Flex Single Stage Venous Cannula (Edwards Lifesciences LLC) and Dual Stage Venous Drainage Cannula (Edwards Lifesciences LLC) offer size alternatives. Their sizes were chosen to closely match those of the three-stage and VAD cannulae.

Water was chosen as a test medium, but a more viscous medium can change the pre-collapse conditions. The main focus of this study, however, was cannula performance during inlet obstruction. In collapse, an increased viscosity can favor the distinction among different cannula tip designs, as unimpeded flow through the remaining open gaps is aggravated.

\section{CONCLUSION}

In vitro testing of cannulae used for proximal venous drainage shows that enhanced tip design can positively affect drainage. When venous return is limited (e.g., during inlet obstruction), cannulae with swirled and grooved tip structures offer better drainage performance.

\section{ACKNOWLEDGMENT}

The authors would like to thank Mr. Erik J.M. Dortangs for his assistance while measuring hydraulic conductance of the venous cannulae, and Mr. Patrick R.G. Blyau for the open and enthusiastic discussions. The authors are grateful to the Foundation European Congress on Extracorporeal Circulation Technology (FECECT), who distinguished this work with the Most Original Paper Award at the $12^{\text {th }}$ European Congress on Extracorporeal Circulation Technology. 


\section{REFERENCES}

1. Gerritsen WB, van Boven WJ, Wesselink RM, Smelt M, Morshuis WJ, van Dongen HP, Haas FJ, Aarts LP. Significant reduction in blood loss in patients undergoing minimal extracorporeal circulation. Transfusion medicine (Oxford, England). 2006;16:329-34.

2. Fromes Y, Gaillard D, Ponzio O, Chauffert M, Gerhardt MF, Deleuze P, Bical OM. Reduction of the inflammatory response following coronary bypass grafting with total minimal extracorporeal circulation. Eur J Cardiothorac Surg. 2002;22:527-33.

3. van Boven WJ, Gerritsen WB, Waanders FG, Haas FJ, Aarts LP. Mini extracorporeal circuit for coronary artery bypass grafting: initial clinical and biochemical results: a comparison with conventional and off-pump coronary artery bypass grafts concerning global oxidative stress and alveolar function. Perfusion. 2004;19:239-46.

4. von Segesser LK, Tozzi P, Mallbiabrrena I, Jegger D, Horisberger J, Corno A. Miniaturization in cardiopulmonary bypass. Perfusion. 2003;18:219-24.

5. Kurusz M, Deyo DJ, Sholar AD, Tao W, Zwischenberger JB. Laboratory testing of femoral venous cannulae: effect of size, position and negative pressure on flow. Perfusion. 1999;14:37987.

6. Simons AP, Reesink KD, Molegraaf GV, van der Nagel T, de Jong MMJ, Severdija EE, de Jong DS, van der Veen FH, Maessen JG. An in vitro and in vivo study of the detection and reversal of venous collapse during extracorporeal life support. Artif Organs. 2007;31:152-9.

7. Reesink K, Dekker A, Van der Nagel T, Beghi C, Leonardi F, Botti P, et al. Suction due to left ventricular assist: implications for device control and management. Artif Organs. 2007;31:5429.

8. Mulholland JW, Massey W, Shelton JC. Investigation and quantification of the blood trauma caused by the combined dynamic forces experienced during cardiopulmonary bypass. Perfusion. 2000;15:485-94.

9. Lapietra A, Grossi EA, Pua BB, Esposito RA, Galloway AC, Derivaux CC, Glassman LR, Culliford AT, Ribakove GH, Colvin SB. Assisted venous drainage presents the risk of undetected air microembolism. J Thorac Cardiovasc Surg. 2000;120:856-62.

10. Girod G, Jaussi A, Rosset C, De Werra P, Hirt F, Kappenberger L. Cavitation versus degassing: in vitro study of the microbubble phenomenon observed during echocardiography in patients with mechanical prosthetic cardiac valves. Echocardiography (Mount Kisco, NY. 2002;19:531-6.

11. Kutschka I, Schonrock U, El Essawi A, Pahari D, Anssar M, Harringer W. A new minimized perfusion circuit provides highly effective ultrasound controlled deairing. Artif Organs. 2007;31:215-20.

12. Martens S, Dietrich M, Pietrzyk R, Graubitz K, Keller H, Moritz A. Elimination of microbubbles from the extracorporeal circuit: dynamic bubble trap versus arterial filter. Int J Artif Organs. 2004;27:55-9.

13. Morita M, Yozu R, Matayoshi T, Mitsumaru A, Shin H, Kawada S. Closed circuit cardiopulmonary bypass with centrifugal pump for open-heart surgery: new trial for air removal. Artif Organs. 2000;24:442-5.

14. Mueller XM, Tevaearai HT, Jegger D, Augstburger M, Burki M, von Segesser LK. Ex vivo testing of the Quart arterial line filter. Perfusion. 1999;14:481-7.

15. von Segesser LK, Jegger D, Mucciolo G, Tozzi P, Mucciolo A, Delay D, Mallabiabarrena I, Horisberger J. The Smartcanula: a new tool for remote access perfusion in limited access cardiac surgery. Heart Surg Forum. 2005;8:E241-5. 
16. Jegger D, Corno AF, Mucciolo A, Mucciolo G, Boone Y, Horisberger J, Seigneul I, Jachertz M, von Segesser LK. A prototype paediatric venous cannula with shape change in situ. Perfusion. 2003;18:61-5.

17. Jegger D, Mueller X, Mucciolo G, Mucciolo A, Boone Y, Seigneul I, Horisberger J, von Segesser LK. A new expandable cannula to increase venous return during peripheral access cardiopulmonary bypass surgery. Int J Artif Organs. 2002;25:136-40.

18. Park JY, Park CY, Min BG. A numerical study on the effect of side hole number and arrangement in venous cannulae. J Biomech. 2007;40:1153-7.

19. Humphries K, Sistino JJ. Laboratory evaluation of the pressure flow characteristics of venous cannulas during vacuum-assisted venous drainage. J Extra Corpor technol. 2002;34:111-4.

20. Ni Y, Leskosek B, Shi L, Chen Y, Qian L, Li R, Tu Z, Segesser LK. Optimization of venous return tubing diameter for cardiopulmonary bypass. European Journal of Cardio-Thoracic Surgery. 2001;20:614-20.

21. Delius RE, Montoya JP, Merz SI, McKenzie J, Snedecor S, Bove EL, Bartlett RH. New method for describing the performance of cardiac surgery cannulas. Ann Thorac Surg. 1992;53:278-81.

22. Bennett EV, Jr., Fewel JG, Ybarra J, Grover FL, Trinkle JK. Comparison of flow differences among venous cannulas. Ann Thorac Surg. 1983;36:59-65.

23. Arom KV, Ellestad C, Grover FL, Trinkle JK. Objective evaluation of the efficacy of various venous cannulas. J Thorac Cardiovasc Surg. 1981;81:464-9.

24. Klabunde RE. Vascular Function. In: Sun B, ed. Cardiovascular Physiology Concepts. 1st ed. Baltimore MD, Philadelphia PA: Lippincott Williams \& Wilkins 2005:111.

25. Amoore JN, Santamore WP. Venous collapse and the respiratory variability in systemic venous return. Cardiovasc Res. 1994;28:472-9. 



\section{CHAPTER 4}

\section{DYNAMIC FILLING INDEX:}

A NOVEL PARAMETER TO MONITOR

CIRCULATORY FILLING DURING

MINIMIZED EXTRACORPOREAL BYPASS

\section{Chapter 4}

Presented in part at the 8th Conference on Perfusion Education and Training, held September 13, 2008 in Lissabon, Portugal.

\section{Published as:}

Simons $A P$, Reesink KD, Lance $M D$, van der Veen FH, de Jong DS, Weerwind PW, Maessen JG. Dynamic filling index: a novel parameter to monitor circulatory filling during minimized extracorporeal bypass. Eur J Cardiothorac Surg. 2009;36:330-4. 


\section{Abstract}

To evaluate the dynamic filling index, a novel parameter to monitor changes in venous return and drainable volume, in circulatory assisted patients. Minimized extracorporeal bypass systems lack volume buffering capacity, demanding tight control of drainable volume to maintain bypass flow. Therefore, with patients on minimized bypass quantitative assessment of venous drainable volume is crucial. In seven patients undergoing coronary artery bypass grafting using minimized extracorporeal bypass we utilized luxation of the heart to induce a reduction in venous return. The speed of the centrifugal pump was transiently and periodically reduced to monitor resultant changes in bypass flow. The dynamic filling index, a measure of drainable volume, was calculated as $\Delta$ flow/ $\Delta$ speed. With luxation, the dynamic filling index was significantly reduced (from $2.4 \pm 0.2$ to $2.0 \pm 0.2 \mathrm{ml} /$ rotation, $\mathrm{p}=0.001 ; 95 \%$ confidence interval of mean difference: $0.23-0.46 \mathrm{ml} /$ rotation), whereas routinely recorded parameters, like bypass flow, pump inlet and arterial line pressure, did not change significantly. The intra-measurement reproducibility for the dynamic filling index was $0.5 \mathrm{ml} /$ rotation ( $20 \%$ of the mean), suggesting good potential for this parameter to monitor on-pump venous return in patients. The dynamic filling index can detect small changes in venous return and drainable volume which remain unrevealed by routinely recorded parameters. This index could be a valuable tool to monitor and control circulatory filling in individual patients supported by minimized extracorporeal bypass. 


\section{INTRODUCTION}

Minimized extracorporeal bypass circuits (MEC) can be used for circulatory support in (postcardiotomy) heart failure, during percutaneous interventions, and in respiratory failure [1-4]. MEC are also used for full cardiopulmonary bypass during heart surgery [5], have been reported to reduce per-operative hemodilution and transfusion requirements, and show a lower incidence of post-operative complications [69]. Despite the advantages and applications MEC offer, venous return remains a matter of concern. These small circuits lack the buffering capacity of a venous reservoir. As a result, the patient's venous vascular system functions as reservoir, and bypass flow directly depends on venous return and resultant drainable volume (DV). DV, however, varies with changes in vascular resistance and conditions leading to reduced venous return, like internal hemorrhage, loss of vascular tone, and capillary leakage.

In previous laboratory studies, we found that the relationship between bypass flow and pump speed in a minimized perfusion setup is modulated by venous return and DV [10, 11]. Figure 1 illustrates the pump flow-pump speed relationship. Bypass flow increases linearly with pump speed if DV is sufficient, but the slope of the curve reduces with decreasing DV. The slope can be characterized by the dynamic filling index (DFI, expressed in $\mathrm{ml} /$ rotation) which acts as a marker of circulatory filling.

In the present study, we tested our method to monitor DV using the DFI in patients to obtain proof of principle in actual clinical context. We assessed the reproducibility of the measurement and its sensitivity to detect changes in venous return in individual patients. 


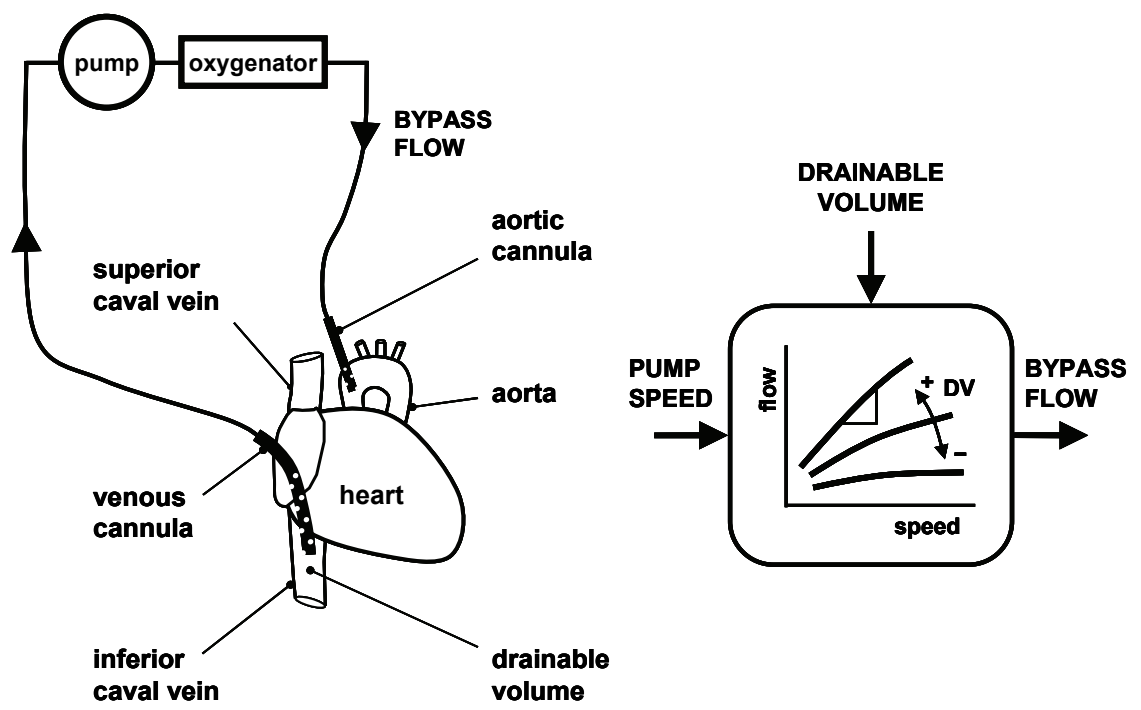

Figure 1 (Left) Configuration of a minimized extracorporeal bypass circuit connected via central cannulation, draining part of the drainable volume. (Right) Drainable volume (DV) modulates the relationship (slope) between pump speed and bypass flow. The slope of the curve can be determined by assessing a change of bypass flow in response to a change in speed (triangle). Calculation of $\Delta$ flow/ $\Delta$ speed results in the slope, and is represented by the dynamic filling index, in $\mathrm{ml} /$ rotation.

\section{MAterials AND Methods}

Informed consent was obtained from all patients included. The study was approved by the medical ethical committee of the Maastricht University Medical Center.

\section{Patients}

We used per-operative data of seven patients undergoing MEC-supported coronary artery bypass grafting (CABG). Patient group age, weight, and length were $64 \pm 8$ years (mean \pm SD), $82 \pm 14 \mathrm{~kg}$, and $1.73 \pm 0.07 \mathrm{~m}$, respectively.

\section{Methods}

During the surgical procedure, the arrested heart is tilted to expose targeted coronary arteries on the posterior aspect of the heart (luxation). It is known that with gross luxation DV is often reduced, as reflected by a decline in bypass flow. After repositioning the heart, bypass flow is normally restored. Heart luxation and repositioning were utilized to induce changes in DV. Care was taken not to obstruct the venous cannula inlet. Figure 2 illustrates the changes in DV with luxation in venograms obtained by transesophageal echocardiography. 


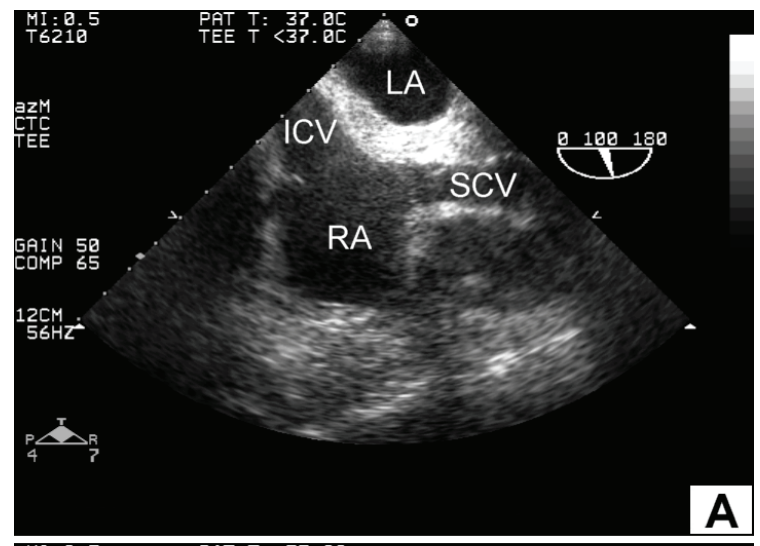

Figure 2 Transesophageal echocardiography venograms in midesophageal bicaval view, showing right atrium (RA), left atrium (LA), inferior caval vein (ICV), superior caval vein (SCV), and a venous cannula inserted in the right auricle. Compared to normal filling (A), right atrium diameter was reduced and the inferior caval vein collapsed with luxation of the heart (B). Venogram C shows a condition with the heart in

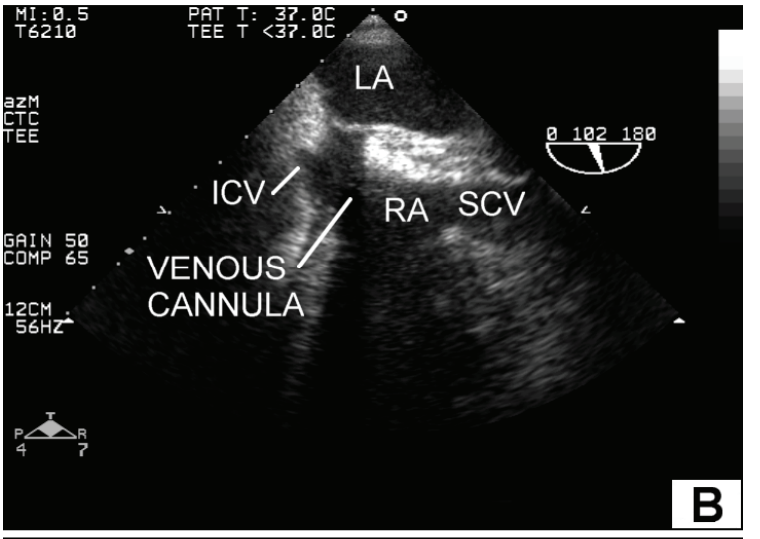
normal position (no luxation) but with reduced filling (patient drained). Note the similarity between (B) and (C).

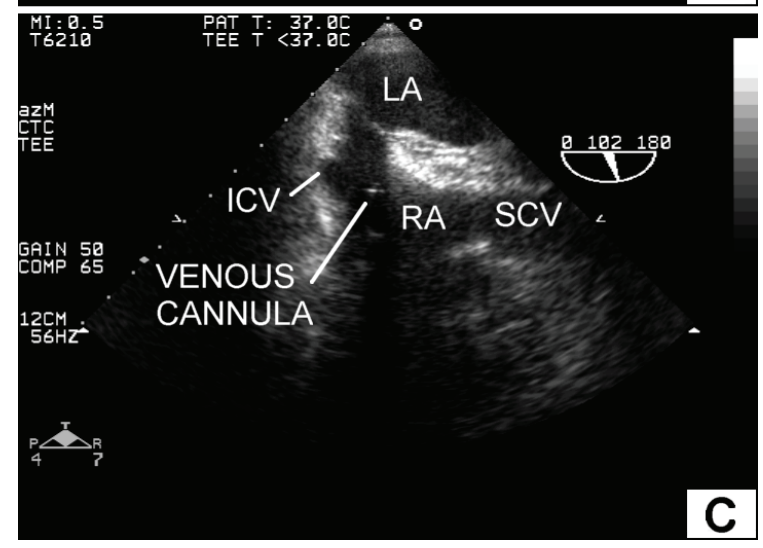

During MEC support, pump speed manipulations are used routinely by the perfusionist to assure proper drainage of bypass flow. To quantify the instantaneous slope of the flow-speed relationship by the DFI (Figure 1), pump speed was periodically and manually manipulated to create sequences consisting of three consecutive transient speed reductions (-100 rpm), each lasting $10 \mathrm{~s}$, superimposed on the steady 
state pump speed. Consequently, each DFI measurement sequence took $50 \mathrm{~s}$ to perform.

The extracorporeal perfusion circuit comprised a Rotaflow centrifugal pump and Quadrox oxygenator (Maquet MECC Circuit, Maquet Cardiopulmonary AG, Hirrlingen, Germany). A 29 Fr Opti-Flow cannula (Stöckert, Sorin Group Italia S.r.l., Mirandola Mo, Italy) was used for central venous cannulation. During bypass anesthesia was preserved by propofol (2-4 mg/kg/h, i.v.) and intermittent boluses of sufentanil $(0.1 \mu \mathrm{g} / \mathrm{kg}$, i.v.). Activated clotting time was monitored during the procedure and maintained above $480 \mathrm{~s}$. Hemodynamic parameters, i.e. arterial line pressure (parterial line) and pump inlet pressure ( $p_{\text {pumpinlet}}$ ), were measured using the pressure sensors integrated in the pump console (Medtronic Inc., Minneapolis, MN, USA). ppumpinlet was measured $10-20 \mathrm{~cm}$ upstream of the pump inlet. parterial line, which is directly linked to aortic blood pressure [12], was measured just upstream of the arterial line filter. Bypass flow was measured via the electromagnetic flow sensor of the Biomedicus pump console. Measured values for pump speed, bypass flow, pump inlet, and parterial line were acquired continuously by the pump console, and transmitted via direct serial communication link to a PC at an update rate of $1 \mathrm{~Hz}$.

\section{Data processing and statistical analysis}

For both bypass flow and pump speed three samples preceding each speed manipulation (down and up) were taken and averaged by taking the median value (Figure 3, points A-F). From the averages per point, five DFI values were calculated by dividing the measured change in flow by the induced change in speed ( $\Delta$ flow/ $\pm 100 \mathrm{rpm}$, in $\mathrm{ml} /$ rotation). An average DFI value per measurement sequence was calculated by taking the median of the five DFI realizations. Average parterial line and pumpinlet were calculated from the corresponding samples taken at steady state pump speed (A, C, and E) during the DFI measurement sequence.

To obtain a measure for the within-sequence variability for the DFI and the other parameters, we calculated the intra-sequence reproducibility (ISR) over the group. ISR is defined as the standard deviation over all errors of the individual realizations with respect to the average values per sequence. The ISR was determined from 30 measurement sequences.

Depending on per-operative conditions like number of distal anastomoses, or hemodynamic instability during DFI measurement, the number of measurement sequences used to determine the DFI varied from 2 to 7 , and was 4 on average for each subject for both positions of the heart (luxation and no luxation). All obtained DFI measurement sequences were included in the analyses. 


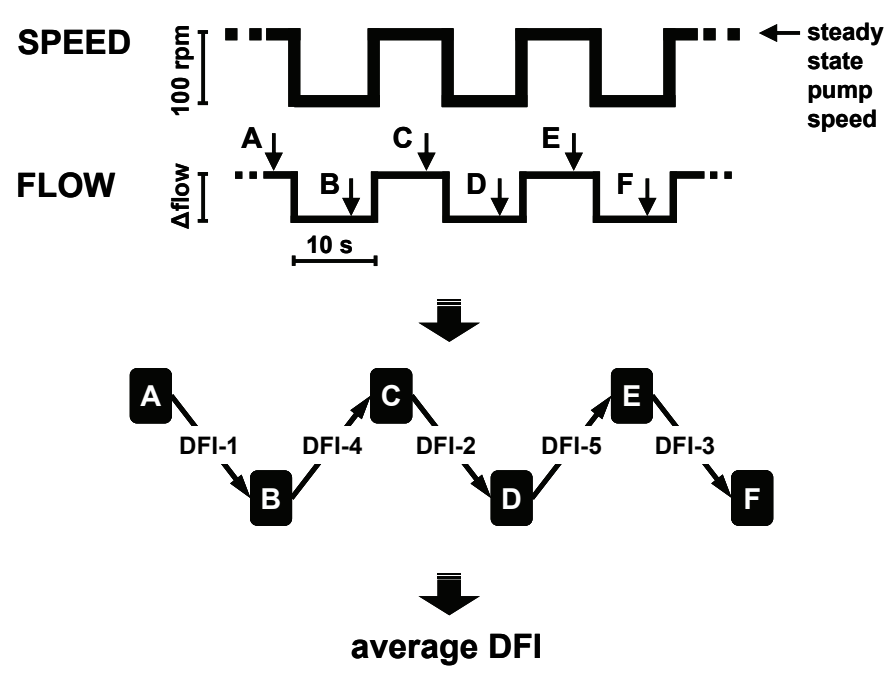

Figure 3 Illustration of a DFI measurement sequence. Changes in pump speed are superimposed on the steady state pump speed. At each point (A-F) bypass flow was sampled three times (within $3 \mathrm{~s}$ ). For each point the median value of the 3 samples was taken as an average per point. Subsequently, five DFI values (DFI-1 to DFI-5) were calculated by dividing the measured change in flow ( $\Delta$ flow) by the induced change in speed $( \pm 100 \mathrm{rpm})$. The median of these five DFI values represents the average value per measurement sequence.

Data are given as mean \pm SD. Differences in hemodynamic and pump-related parameters and the DFI between the luxation and no luxation conditions were compared using a paired Student t-test, assuming equal variance (MS Excel 2003, Microsoft Corp., Redmond, WA, USA). All $\mathrm{p}$ values below 0.05 were considered statistically significant.

\section{RESUlts}

The effect of the pump speed manipulations on bypass flow is illustrated in Figure 4 . The figure shows pump speed, bypass flow, the calculated DFI, ppumpinet, and parterial line, during luxation, no luxation and extreme luxation. During each phase, the DFI measurement sequences are visible as triplets of reduced speed with corresponding changes in bypass flow, ppump inlet, and parterial line.

During luxation of the heart, the first DFI reads $2.1 \mathrm{ml} /$ rotation with a standard deviation of $1.6 \mathrm{ml} /$ rotation. The subsequent DFI measurement shows considerably lower intra-sequence variability, but a comparable average value. In the next phase (no luxation) the changes in bypass flow in response to the induced changes in pump speed were larger, resulting in an increased average DFI $(2.5 \pm$ $0.4 \mathrm{ml} /$ rotation). The observed difference in variability between no luxation 
( $\mathrm{SD}=0.4 \mathrm{ml} /$ rotation) and luxation $(\mathrm{SD}=0.2 \mathrm{ml} /$ rotation) indicates that the observed mean difference $(2.5-2.0=0.5 \mathrm{ml} /$ rotation) is statistically borderline detectable. The last phase in Figure 4 (extreme luxation) shows a steeply declined DFI value, indicating significantly reduced drainable volume $(\mathrm{p}<0.0001)$. This impediment of drainage by the MEC system is also evident from a clear reduction in bypass flow (from 4.5 to $2.61 / \mathrm{min}$ ).
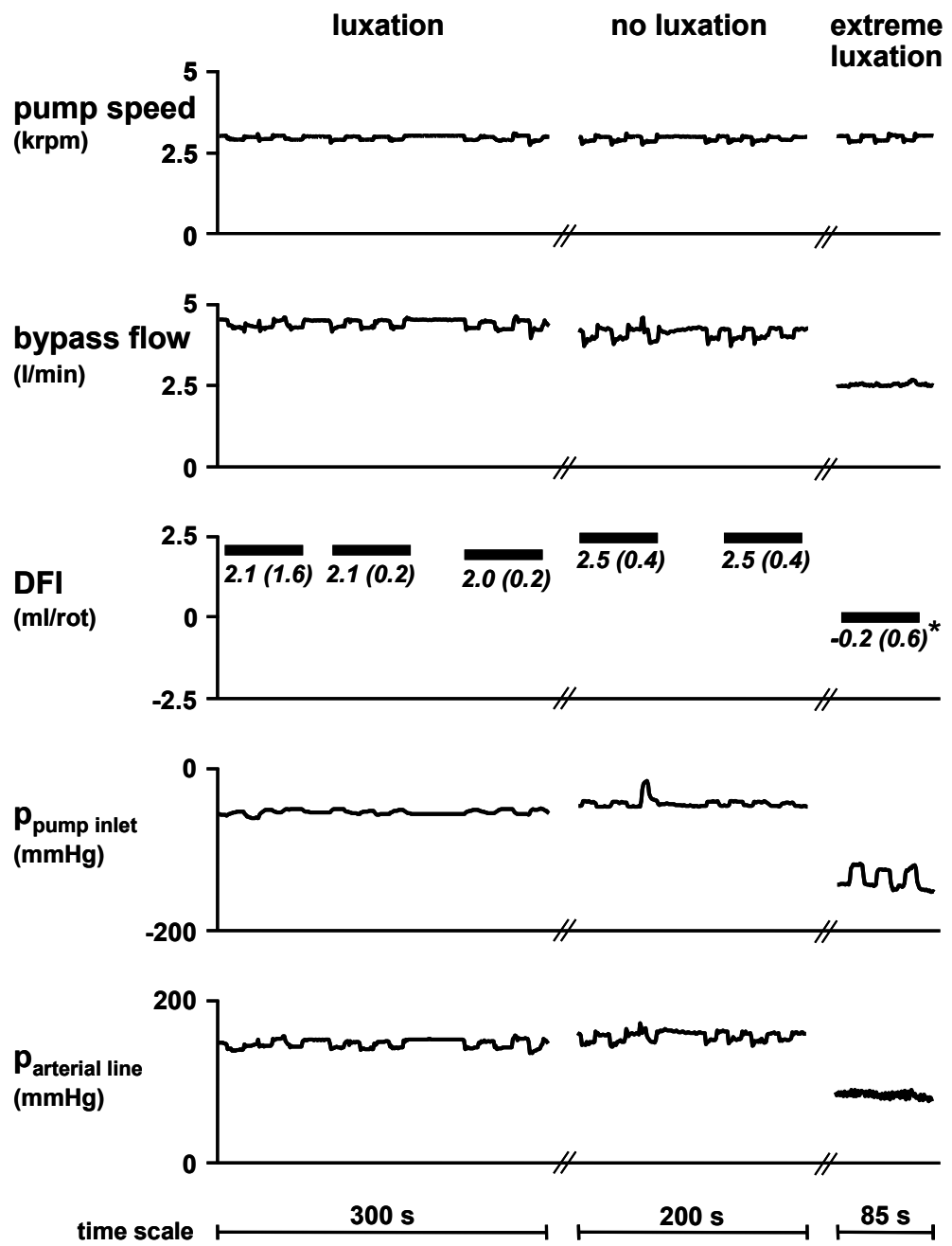

Figure 4 The dynamic filling index (DFI, in $\mathrm{ml} /$ rotation) reflects changes in drainable volume related to manipulation of the heart during CABG. The DFI values represent averages per measurement sequence and intra-sequence reproducibility (in brackets). A DFI measurement with extreme luxation (shown) was obtained in this patient only. ${ }^{*} \mathrm{p}<0.0001$ : DFI at extreme luxation compared to the average DFI with luxation and no luxation. ppumpinlet, pump inlet pressure; parterial line, arterial line pressure. 
Table 1 shows hemodynamic and pump-related parameters, and the DFI during heart luxation and no luxation for the group. The change in the DFI with luxation was statistically significant $(\mathrm{p}=0.001)$, whereas bypass flow, pumpinlet, and parterial line did not change significantly. The $95 \%$ confidence interval of the difference in DFI was 0.23 to $0.46 \mathrm{ml} /$ rotation. For the DFI the ISR was of the same order of magnitude as the observed change in the DFI.

Table 1 Hemodynamic parameters and DFI during luxation and after repositioning.

\begin{tabular}{llllllll}
\hline & & no luxation & & & luxation & & \\
\cline { 3 - 4 } & & mean \pm SD & ISR & & mean \pm SD & ISR & p-value* \\
\hline bypass flow & $1 / \mathrm{min}$ & $4.64 \pm 0.38$ & 0.04 & & $4.72 \pm 0.37$ & 0.04 & 0.50 \\
pump speed & $\mathrm{rpm}$ & $3071 \pm 142$ & 7 & & $3031 \pm 172$ & 7 & 0.23 \\
DFI & $\mathrm{ml} /$ rotation & $2.4 \pm 0.2$ & 0.5 & & $2.0 \pm 0.2$ & 0.4 & 0.001 \\
ppump inlet & $\mathrm{mmHg}$ & $-50 \pm 11$ & 1 & & $-49 \pm 9$ & 1 & 0.84 \\
parterial line & $\mathrm{mmHg}$ & $161 \pm 14$ & 1 & & $155 \pm 12$ & 1 & 0.15 \\
\hline
\end{tabular}

Values represent mean \pm standard deviation (SD) over 7 patients and intra-sequence reproducibility (ISR) averaged over the group. DFI, dynamic filling index; ppump inlet, pump inlet pressure; parterial line, arterial line pressure. *Luxation compared to no luxation; paired Student's t-test.

\section{Discussion}

In the present study, we demonstrated that pump speed manipulations can be used to obtain an index (DFI) for drainable volume (DV) in MEC-supported patients. The DFI appears to be more sensitive to changes in DV than the direct hemodynamic and pump-related parameters.

In our patients, the DFI revealed a significant reduction in DV during luxation of the heart (Table 1). The severe reduction in the DFI we recorded in one of our subjects (Figure 4) was the result of substantial cannula obstruction and/or caval vein occlusion with extreme luxation. In a previous study, we showed that such a decrease in the DFI is indicative of insufficient volume available for drainage [11]. The present study demonstrates that even small changes in DV can be detected by DFI measurement. In contrast, bypass flow, ppumpinlet, and parterial line did not reveal a change in DV (Table 1).

The measurement of DFI requires manipulations of pump speed of sufficient magnitude and at well-defined time intervals. Theoretically, measurement of the incremental flow-speed ratio ( $\mathrm{d}_{\text {flow }} / \mathrm{d}_{\text {speed }}$ ) would enable a comprehensive reconstruction of the flow-speed curve. As our data indicate, however, a certain minimum drop in pump speed is required to induce a detectable change in pump flow. The $100 \mathrm{rpm}$ reduction in pump speed we employed proved to be sufficient to measure DFI in our patient group. Moreover, our sampling method and median averaging 
effectively suppressed noise in the DFI due to 'normal' variability in the measured flow. The DFI measurement currently utilizes $10 \mathrm{~s}$ intervals of reduced speed. In our study, bypass flow reached a steady state within the speed manipulation interval. The safety and sensitivity of DFI measurement, as determined by the amplitude and timing parameters, remain to be established in a wider range of clinical MEC applications.

DFI measurement specifically utilizes the direct modulation of drainage flow by pump speed. In any circuit containing a venous reservoir, drainage flow and pump speed are decoupled, rendering DFI measurement unsuitable.

To evaluate the potential of the DFI to monitor changes in DV in individual patients, the variability in single DFI measurements should be smaller than the difference in DFI observed with subsequent measurements. Our results (Table 1) indicate that, in the present setup, DFI cannot discriminate differences smaller than $0.5 \mathrm{ml} /$ rotation (ISR) within individuals. In order to detect changes in DV in an individual patient, those changes need to be at least greater than the ISR as determined in our patients.

We employed manipulations of the heart during coronary bypass surgery in order to modulate DV. Although the effect of luxating the heart created reproducible changes in DFI, we did not obtain in our patients alternative evidence for the absolute changes in DV. In previous studies performed under well-controlled conditions we have demonstrated that the DFI responds straightforwardly to caval vein constriction and changes in transmural pressure at the drainage site [11]. The DFI may also be affected by a change in arterial line pressure. In the present study, however, arterial line pressure did not change significantly. Luxation of the heart may result in cannula obstruction, leading to the obvious reduction in bypass flow. In our experiments we made sure that with luxation the cannula tip was not obstructed. Moreover, a previous study on cannula performance revealed high resistance against inlet obstruction for the cannula used in this study [10]. Therefore, the observed changes in DFI are likely to reflect changes in DV, as induced by limiting venous return.

Other investigators have reported both static and dynamic assessment methods to detect acute drainage impediment and pumping failure [13-18]. The approach in these studies was to characterize pumping conditions for device control purposes, whereas our focus was on patient condition and interaction with the support system. To the best of our knowledge, our study is the first to investigate quantitative assessment of venous return and volume available for drainage in patients supported with MEC. In future studies, we will apply DFI measurements in medium- to long-term MEC supported patients in the intensive care unit, and make a comparative evaluation between the DFI and routinely used methods to assess venous return and patient filling [19]. 


\section{CONCLUSION}

During MEC support venous return, as reflected by the volume that can be drained by the system, can be assessed by measuring the dynamic filling index. This parameter could be a valuable tool to monitor circulatory filling in patients supported by minimized extracorporeal circulatory support systems. 


\section{REFERENCES}

1. Immer FF, Ackermann A, Gygax E, Stalder M, Englberger L, Eckstein FS, Tevaearai HT, Schmidli J, Carrel TP. Minimal extracorporeal circulation is a promising technique for coronary artery bypass grafting. Ann Thorac Surg. 2007;84:1515-20; discussion 21.

2. Fromes Y, Gaillard D, Ponzio O, Chauffert M, Gerhardt MF, Deleuze P, Bical OM. Reduction of the inflammatory response following coronary bypass grafting with total minimal extracorporeal circulation. Eur J Cardiothorac Surg. 2002;22:527-33.

3. Formica F, Avalli L, Martino A, Maggioni E, Muratore M, Ferro O, Pesenti A, Paolini G. Extracorporeal membrane oxygenation with a poly-methylpentene oxygenator (Quadrox D). The experience of a single Italian centre in adult patients with refractory cardiogenic shock. Asaio J. 2008;54:89-94.

4. Bartlett RH, Roloff DW, Custer JR, Younger JG, Hirschl RB. Extracorporeal life support: the University of Michigan experience. Jama. 2000;283:904-8.

5. Castiglioni A, Verzini A, Pappalardo F, Colangelo N, Torracca L, Zangrillo A, Alfieri O. Minimally invasive closed circuit versus standard extracorporeal circulation for aortic valve replacement. Ann Thorac Surg. 2007;83:586-91.

6. Abdel-Rahman U, Ozaslan F, Risteski PS, Martens S, Moritz A, Al Daraghmeh A, Keller H, Wimmer-Greinecker $G$. Initial experience with a minimized extracorporeal bypass system: is there a clinical benefit? Ann Thorac Surg. 2005;80:238-43.

7. van Boven WJ, Gerritsen WB, Waanders FG, Haas FJ, Aarts LP. Mini extracorporeal circuit for coronary artery bypass grafting: initial clinical and biochemical results: a comparison with conventional and off-pump coronary artery bypass grafts concerning global oxidative stress and alveolar function. Perfusion. 2004;19:239-46.

8. Wiesenack C, Liebold A, Philipp A, Ritzka M, Koppenberg J, Birnbaum DE, Keyl C. Four years' experience with a miniaturized extracorporeal circulation system and its influence on clinical outcome. Artif Organs. 2004;28:1082-8.

9. Gerritsen WB, van Boven WJ, Wesselink RM, Smelt M, Morshuis WJ, van Dongen HP, Haas FJ, Aarts LP. Significant reduction in blood loss in patients undergoing minimal extracorporeal circulation. Transfusion medicine (Oxford, England). 2006;16:329-34.

10. Simons AP, Ganushchak Y, Wortel P, van der Nagel T, van der Veen FH, de Jong DS, Maessen JG. Laboratory performance testing of venous cannulae during inlet obstruction. Artif Organs. 2008;32:566-71.

11. Simons AP, Reesink KD, Molegraaf GV, van der Nagel T, de Jong MMJ, Severdija EE, de Jong DS, van der Veen FH, Maessen JG. An in vitro and in vivo study of the detection and reversal of venous collapse during extracorporeal life support. Artif Organs. 2007;31:152-9.

12. Meurs van K. ECMO: extracorporeal cardiopulmonary support in critical care. 3rd ed. Ann Arbor: Extracorporeal Life Support Organization 2005.

13. Schima H, Vollkron M, Jantsch U, Crevenna R, Roethy W, Benkowski R, Morello G, Quittan M, Hiesmayr M, Wieselthaler G. First clinical experience with an automatic control system for rotary blood pumps during ergometry and right-heart catheterization. J Heart Lung Transplant. 2006;25:167-73.

14. Gwak KW, Ricci M, Snyder S, Paden BE, Boston JR, Simaan MA, Antaki JF. In vitro evaluation of multiobjective hemodynamic control of a heart-assist pump. Asaio J. 2005;51:329-35.

15. Ohuchi K, Kikugawa D, Takahashi K, Uemura M, Nakamura M, Murakami T, Sakamoto T, Takatani S. Control strategy for rotary blood pumps. Artif Organs. 2001;25:366-70. 
16. Baloa LA, Liu D, Boston JR, Simaan MA, Antaki JF. Control of Rotary Heart Assist Devices. Proceedings of the 2000 American Control Conference; 2000; Chicago, Illinois; 2000. p. 2982-6.

17. Trinkl J, Havlik P, Mesana T, Mitsui N, Morita S, Demunck JL, Tourres JL, Monties JR. Control of a rotary pulsatile cardiac assist pump driven by an electric motor without a pressure sensor to avoid collapse of the pump inlet. ASAIO J. 1993;39:M237-41.

18. Setz K, Kesser K, Kopotic RJ, Cornish JD. Comparison of a new venous control device with a bladder box system for use in ECMO. ASAIO J. 1992;38:835-40.

19. Vincent J-L. Yearbook of Intensive Care and Emergency Medicine. Berlin, Heidelberg, New York: Springer-Verlag 2007. 



\section{CHAPTER 5}

\section{RESERVE-DRIVEN FLOW CONTROL FOR EXTRACORPOREAL LIFE SUPPORT: PROOF OF PRINCIPLE}

Presented in part at the $38^{\text {th }}$ International Meeting on Perfusion of the German Society for Cardiovascular Engineering, held November 6-8, 2009 in Weimar, Germany.

Published as:

Simons AP, Reesink KD, Lancé MD, van der Nagel T, van der Veen FH, Weerwind PW, Maessen JG. Reserve-driven flow control for extracorporeal life support: proof of principle. Perfusion. 2010;25:25-9. 


\section{Abstract}

Extracorporeal life support systems lack volume buffering capacity. Therefore, any decrease in venous intravascular volume available for drainage may result in acutely reduced support flow. We recently developed a method to quantify drainable volume and now conceived a reserve-driven pump control strategy, which is different from existing pressure or flow servo control schemes. Here, we give an outline of the algorithm and present animal experimental data showing proof of principle. With an acute reduction in circulatory volume (10-15\%), pump flow immediately dropped from 4.1 to $1.9 \mathrm{l} / \mathrm{min}$. Our pump control algorithm could restore bypass flow to $3.2 \mathrm{l} / \mathrm{min}$ (about $80 \%$ of the original level) and, thereby, reduced the duration of the low-flow condition. This demonstrates that a reservedriven pump control strategy, based on the continuous monitoring of drainable volume, may maintain extracorporeal circulatory support flow, despite serious changes in filling condition. 


\section{INTRODUCTION}

Extracorporeal life support (ELS) systems [1-5] lack reservoirs and, therefore, the volume-buffering capacity of full cardiopulmonary bypass systems. With conditions of low patient filling and reduced venous return, maintaining bypass flow can be challenging. A short-lasting reduction in pump preload, for example, may even result in a persistently decreased pump flow [6]. A pump controller that maintains stable bypass flow during low filling conditions, therefore, could be supportive.

Pump control using flow servo regulation aims at maintaining a preset bypass flow. It increases pump speed when flow is reduced, and vice versa. With minimised circuits, however, increasing pump speed results in cannula inlet obstruction when preload is limited and, subsequently, in decline of support flow [7], which renders this so-called demand-driven pump control less suitable for ELS. Pump control constrained by pump inlet pressure decreases pump speed with decreasing pressure level, and vice versa. Pressure measurement, however, has proven less suitable to reveal changes in venous return and patient filling in several cases [8-12]. Moreover, pump control using inlet pressure does not focus on circulatory assistance: it induces a pump stop if pressure exceeds a certain negative level and, thus, may leave the patient without support during the intervention [13, 14].

In general, pump control schemes should be robust, i.e., they should counter fluctuations in haemodynamics, rather than to amplify disturbances. To design a useable control, it is important to consider the underlying dynamics of the interaction between the ELS circuit and the patient circulation.

Figure 1 left illustrates the non-linear speed-flow relationship as a function of venous intravascular volume available for drainage, here coined 'drainable volume' (DV). The loops illustrate that resolving impaired drainage due to inappropriate pump speed (the plateau in the curve) firstly requires a speed reduction, after which an increase of pump speed will restore the balance between venous return and venous drainage [10]. In a recent study, we demonstrated that small changes in DV, as reflected by the slope of the speed-flow curve (Figure 1 right), can be determined by measuring the dynamic filling index (DFI) [12]. This index proved more sensitive to changes in DV than direct haemodynamic and pump-related parameters. Continuous monitoring of DV during ELS provides the possibility of running a reservedriven control scheme, based on what flow the ELS circuit may deliver at a certain instant rather than what the circuit ideally should deliver (demand-driven). 

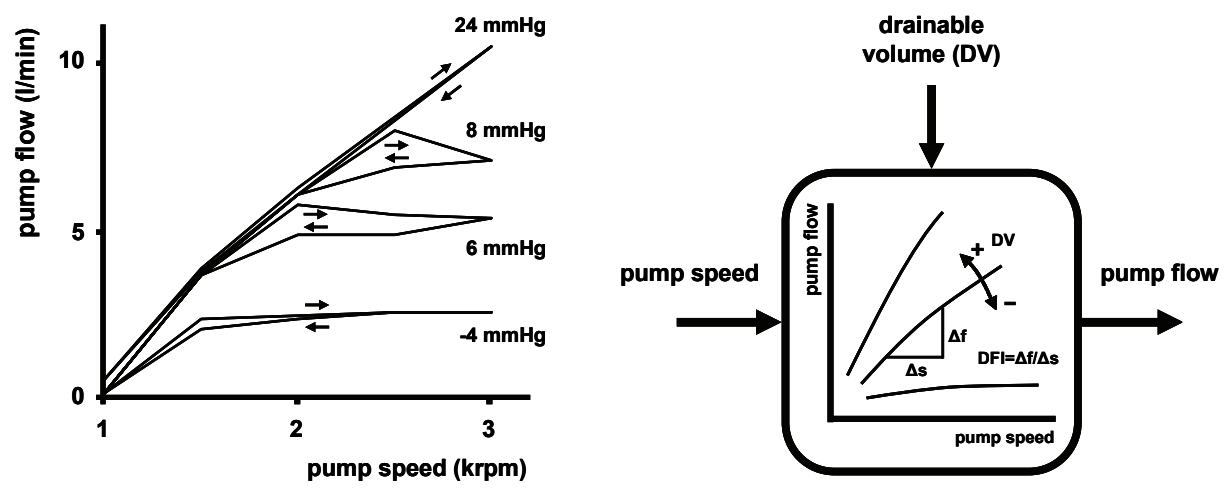

Figure 1 Illustration of the relationship between pump speed, venous intravascular volume available for drainage, and pump flow in a veno-arterial extracorporeal life support configuration. (Left) With sufficient preload ( $24 \mathrm{mmHg}$ ), an increase of pump speed nearly linearly increases pump flow. In contrast, with insufficient preload pump, flow tends to plateau at higher pump speeds and the initial near-linear speed-flow relationship transforms to unidirectional loops (unpublished data from [10]). (Right) Venous intravascular volume available for drainage ('drainable volume', DV) can be quantified by measuring the slope of the curve [12].

The aim of the present study was to demonstrate in an animal model proof-ofprinciple for a reserve-driven pump control strategy for ELS. Our strategy is to sense DV, using DFI measurement, and to maintain, by using smart pump speed adjustments, the maximum available level of support flow despite significant changes in filling condition.

\section{Materials ANd Methods}

\section{Hardware and software}

A centrifugal pump (Rotaflow32 and Rotaflow drive unit and operator console, Maquet Cardiopulmonary AG, Hirrlingen, Germany) was completed with a 10-bit digital potentiometer (Instrument Development Engineering \& Evaluation - IDEE, Maastricht University Medical Centre, Maastricht, the Netherlands). A serial RS232 connection enabled computer pump operation. Pump flow and speed readouts provided by the console were sent to the computer via a second serial communication connection (RS232). The interface to computer-operate the pump and acquire pump data was programmed in LabVIEW (National Instruments, Austin, TX, USA).

\section{Control algorithm}

A block diagram illustrating the control algorithm is shown in Figure 2. A single measurement of a dynamic filling index (DFI) involves three consecutive transient speed reductions of $10 \mathrm{~s}$ and $100 \mathrm{rpm}$ each. The resulting changes in pump flow are 
measured, and the DFI is calculated using $\Delta$ pump flow/ $\Delta$ pump speed [12]. The periodically measured DFI is compared with a preset DFI threshold value.

If the actual DFI falls below a certain preset threshold (see below), pump speed is reduced to $50 \%$ for 5 seconds first, and then increased to $95 \%$ of the initial value [10]. After the 2-step intervention, the DFI is re-evaluated.

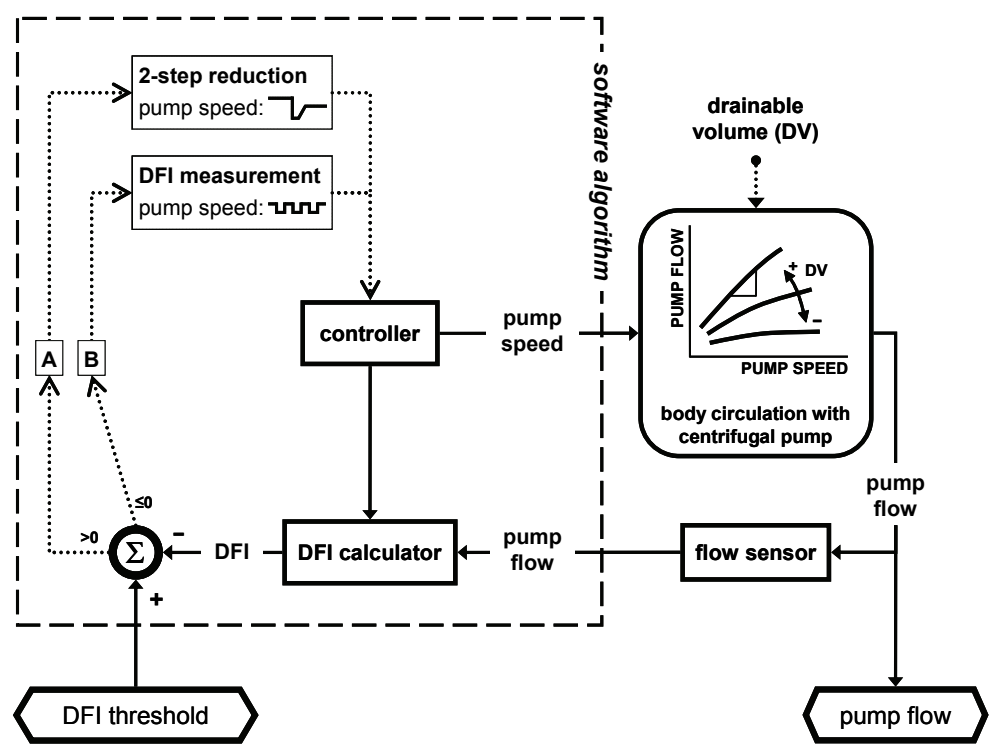

Figure 2 Block diagram showing the proposed reserve-driven pump control based on dynamic filling index (DFI) measurement. If the actual DFI falls below the threshold (option A) the controller will initialize a 2-step pump speed intervention. When the controller is idling, DFI is re-evaluated periodically by small perturbations in pump speed (option B).

\section{Experimental protocol}

A female goat of $66 \mathrm{~kg}$ was anaesthetised and intubated. After thoracotomy, and with an activated clotting time $>480 \mathrm{~s}$, the ELS (PLS Circuit, Maquet Cardiopulmonary AG, Hirrlingen, Germany) was installed. After stabilization of bypass flow, manual pump control was switched to computer control and an initial DFI value was measured using three consecutive pump speed manipulations [12]. The DFI threshold was calculated as DFIthreshold $=1 / 2 * D^{*} I_{\text {initial, }}$ and entered into the program. An acute reduction in DV was induced by acute withdrawal of 0.5 litres of blood from the circulation (approximately $10-15 \%$ of the total blood volume) via the ELS, using the arterial line.

During the experiment, propofol i.v. was used to maintain anaesthesia. Analgesia was achieved by buprenorfine and flunixin infusion. Peroperative monitoring included electrocardiogram (ECG), peripheral blood pressure, oxygen saturation, and capnography. At the end of the experiment, the goat was sacrificed by pento- 
barbital overdose. The experiment was approved by the local ethical committee. The animal received humane care in compliance with the "Guide for the Care and Use of Laboratory Animals" (NIH publication 86-23, 1985 revision; National Institute of Health, USA).

\section{Results}

The effect of the acute blood volume withdrawal and the response of the pump control are shown in Figure 3. The sequences of small pump speed manipulations for DFI measurement are clearly visible in the speed and flow tracings. The initial pump speed of 3,200 rpm induced a pump flow of $4.11 / \mathrm{min}$ and the initial DFI was $1.7 \mathrm{ml} /$ rotation (episode A in Figure 3), and, therefore, the DFIthreshold was set to $0.85 \mathrm{ml} /$ rotation. The acute reduction in blood volume (arrow) resulted in an oscillating flow pattern after about one minute, reflecting developing disproportionate drainage (episode B). As excessive drainage continued to exist, pump flow dropped to $1.9 \mathrm{l} / \mathrm{min}$ (episode C). Three consecutive 2-step pump speed interventions with a total speed decrease of $15 \%$, down to $2,700 \mathrm{rpm}$ steady state (episodes C-E), resolved the condition of excessive drainage and resulted in a pump flow of $3.2 \mathrm{l} / \mathrm{min}$ (episode F). The DFI measurements during the new steady state (episodes $G, H$ ) indicated a drainage ( $\mathrm{ml}$ per pump cycle) comparable to that before volume loss. 


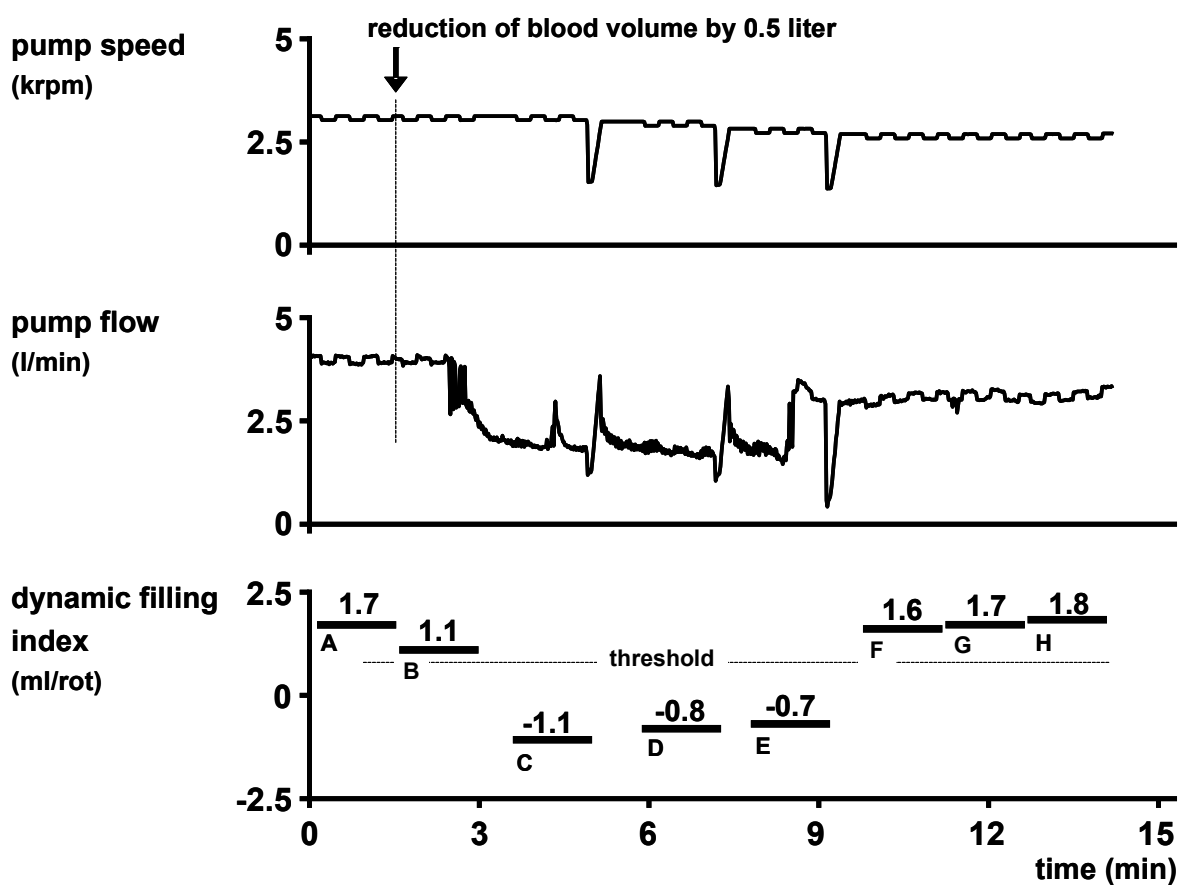

Figure 3 An acute reduction of blood volume (arrow) results in steeply reduced pump flow. The insufficient venous intravascular volume available for drainage is reflected by the decrease in dynamic filling index. Following episodes C, D and E (DFI too low), the pump controller initiates a 2-step intervention. A, stable pump flow; B-E, disproportionate drainage as indicated by the DFI; F-H, pump flow restored to $80 \%$, with the DFI restored to the initial level.

\section{DISCUSSION}

In the present study, we applied a reserve-driven control algorithm to the centrifugal pump of an extracorporeal life support system and evaluated its performance during an episode of critically low filling. Despite a substantial decrease in blood volume, our pump control could automatically re-establish bypass flow to about $80 \%$ of the initial level.

Modern heart-lung machines offer servo regulation to maintain bypass flow. Such servo regulators aim at maintaining flow or pressure at preset values while assuming linear speed-flow or speed-pressure relationships. As illustrated in Figure 1, the relation between pump speed and pump flow in a typical ELS application is de facto non-linear and is characterised by unidirectional loops (hysteresis) [10]. By employing a multi-step speed adjustment, our reserve-driven control scheme is able to cope with the non-linear speed-flow interaction. Existing 
flow servo or pump inlet pressure guided control schemes do not take into account the non-linear dynamics in a low filling/low flow state, but tend to either exhibit runaway behaviour or fully stop the pump when preset limits are reached. Of course, full restoration of support flow to its initial level could not be achieved running our control schema, but this was to be expected as the circulation was still 'missing' 0.51 of blood. Nonetheless, the experimental data shown here demonstrate that a reserve-driven flow control, using the DFI, can monitor drainage and, in part, restore pump flow after an acute loss of circulatory volume, and may shorten the duration of hypoperfusion.

In conclusion, reserve-driven flow control based on the dynamic filling index may reduce the extent and duration of hypoperfusion in ELS supported patients by taking into account the non-linear interaction between circuit and patient circulation. Further studies, however, are required to establish in clinical settings the utility, safety and efficacy of such a control strategy.

\section{ACKNOWLEDGMENT}

The authors would like to thank Maquet Cardiopulmonary AG (Hirrlingen, Germany) for materials and technical support. We are graceful to Mr Patrick R.G. Blyau and Mr Pieter Wortel for the open and stimulating discussions. 


\section{REFERENCES}

1. Cooper DS, Jacobs JP, Moore L, Stock A, Gaynor JW, Chancy T, Parpard M, Griffin DA, Owens T, Checchia PA, Thiagarajan RR, Spray TL, Ravishankar C. Cardiac extracorporeal life support: state of the art in 2007. Cardiology in the young. 2007;17 Suppl 2:104-15.

2. Lemos PA, Cummins P, Lee CH, Degertekin M, Gardien M, Ottervanger JP, Vranckx P, de Feyter P, Serruys PW. Usefulness of percutaneous left ventricular assistance to support highrisk percutaneous coronary interventions. The American journal of cardiology. 2003;91:479-81.

3. Linden V, Palmer K, Reinhard J, Westman R, Ehren H, Granholm T, Frenckner B. Inter-hospital transportation of patients with severe acute respiratory failure on extracorporeal membrane oxygenation - national and international experience. Intensive Care Med. 2001;27:1643-8.

4. Bartlett RH, Roloff DW, Custer JR, Younger JG, Hirschl RB. Extracorporeal life support: the University of Michigan experience. Jama. 2000;283:904-8.

5. Arlt M, Philipp A, Iesalnieks I, Kobuch R, Graf B. Successful use of a new hand-held ECMO system in cardiopulmonary failure and bleeding shock after thrombolysis in massive postpartal pulmonary embolism. Perfusion. 2009;24:49-50.

6. Reesink KD, Dekker A, Van der Nagel T, Beghi C, Leonardi F, Botti P, De Cicco G, Lorusso R, Van der Veen FH, Maessen JG. Suction due to left ventricular assist: implications for device control and management. Artif Organs. 2007;31:542-9.

7. Simons AP, Ganushchak Y, Wortel P, van der Nagel T, van der Veen FH, de Jong DS, van der Veen FH, de Jong DS, Maessen JG. Laboratory performance testing of venous cannulae during inlet obstruction. Artif Organs. 2008;32:566-71.

8. Androne AS, Hryniewicz K, Hudaihed A, Mancini D, Lamanca J, Katz SD. Relation of unrecognized hypervolemia in chronic heart failure to clinical status, hemodynamics, and patient outcomes. The American journal of cardiology. 2004;93:1254-9.

9. Magder S. Central venous pressure monitoring. Current opinion in critical care. 2006;12:219-27.

10. Simons AP, Reesink KD, Molegraaf GV, van der Nagel T, de Jong MMJ, Severdija EE, de Jong DS, van der Veen FH, Maessen JG. An in vitro and in vivo study of the detection and reversal of venous collapse during extracorporeal life support. Artif Organs. 2007;31:152-9.

11. Gelman S. Venous function and central venous pressure: a physiologic story. Anesthesiology. 2008;108:735-48.

12. Simons AP, Reesink KD, Lance MD, van der Veen FH, de Jong DS, Weerwind PW, Maessen JG. Dynamic filling index: a novel parameter to monitor circulatory filling during minimized extracorporeal bypass. Eur J Cardiothorac Surg. 2009;36:330-4.

13. Tamari Y, Lee-Sensiba K, Ganju R, Chan R, Hall MH. A new bladder allows kinetic venous augmentation with a roller pump. Perfusion. 1999;14:453-9.

14. Pedersen TH, Videm V, Svennevig JL, Karlsen H, Ostbakk RW, Jensen O, Mollnes TE. Extracorporeal membrane oxygenation using a centrifugal pump and a servo regulator to prevent negative inlet pressure. Ann Thorac Surg. 1997;63:1333-9. 



\section{CHAPTER 6}

QUANTITATIVE ASSESSMENT OF CARDIAC LOAD-RESPONSIVENESS DURING EXTRACORPOREAL LIFE SUPPORT: CASE AND RATIONALE

Published as:

Simons AP, Lancé MD, Reesink KD, van der Veen FH, Weerwind PW, Maessen JG. Quantitative assessment of cardiac load-responsiveness during extracorporeal lifesupport: case and rationale. J Cardiothorac Surg. 2010;5:30-33. 


\section{Abstract}

We describe a case of a patient assisted by extracorporeal life support, in which we obtained the dynamic filling index, a measure for venous volume during extracorporeal life support, and used this index to assess cardiac load-responsiveness during acute reloading. While reloading, the obtained findings on cardiac pump function by the dynamic filling index were supported by trans-esophageal echocardiography and standard pressure measurement. This suggests that the dynamic filling index can be used to assess cardiac load-responsiveness during extracorporeal life support. 


\section{BACKGROUND}

The successful use of extracorporeal life support (ELS) for cardiopulmonary assist and as bridge to myocardial recovery has been shown in many cases [1-3]. Unfortunately, weaning from extracorporeal life support often relies on preconceived protocols, if any, and is largely based on trial-and-error and limited data on actual cardiac function. The common procedure to assess cardiac recovery during ELS, is the use of stress tests. These tests induce an increased volume load on the myocardium and address the Frank-Starling response. This response can be visualized using trans-esophageal echocardiography (TEE), and further quantified by measurement of blood pressure and cardiac output [4,5]. Volume loading is achieved by reducing ELS flow, upon which, depending on the degree of recovery, the heart will increase its output and maintain arterial and venous blood pressure (Figure 1). In patients whose heart has not (yet) recovered the response is blunted, which causes low output, decreased arterial blood pressure, and increased venous volume.

Recently, we developed a technique to quantitatively assess venous volume that can be (potentially) drained by the centrifugal pump-based ELS circuit, and introduced the dynamic filling index (DFI, in $\mathrm{ml} /$ rotation) for the purpose of optimizing ELS flow [6-8]. DFI measurement uses periodical, transient reductions ( $100 \mathrm{rpm}$ ) of pump speed, each lasting approximately 10 seconds, superimposed on the steady state pump speed. The resultant changes in bypass flow are used to calculate the DFI as $\Delta$ flow/ $\Delta$ speed (Figure 3 in [7]). When venous volume increases the DFI increases, and vice versa. We found that the DFI is more sensitive to detect changes in venous volume than other routinely recorded hemodynamic and pump related parameters, like central venous pressure.

This case shows a patient supported by ELS in which several events of cardiac reloading were performed. In two events, we added DFI measurement to the monitoring of the patient. Before, during, and after reloading, changes in venous volume were quantified using DFI measurement. Under these circumstances, the DFI adequately represented cardiac load-responsiveness as confirmed by TEE. 
NORMAL / IMPROVING

LOAD-RESPONSIVENESS
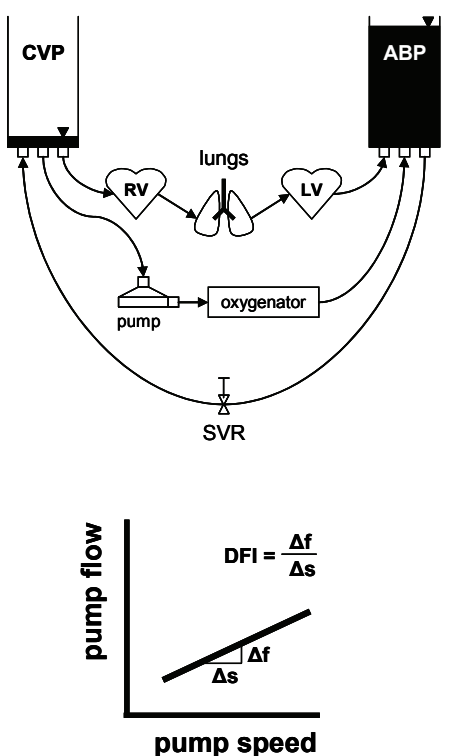

BLUNTED

LOAD-RESPONSIVENESS
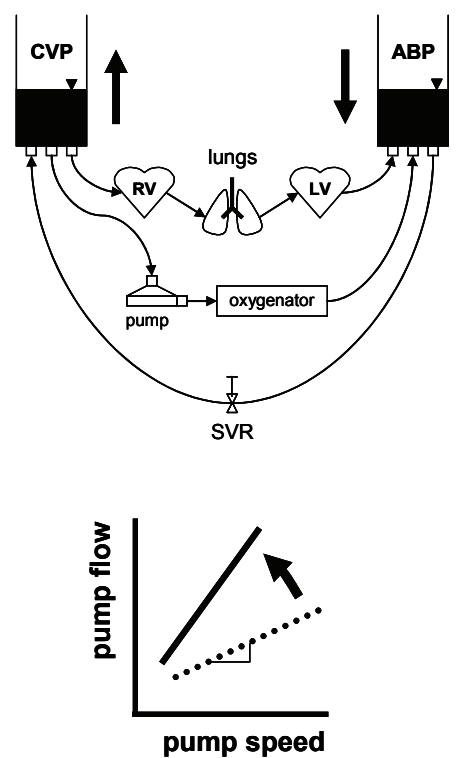

Figure 1 Rationale behind the use of venous volume measurement (dynamic filling index, DFI) in testing cardiac load-responsiveness. With acute reduction of pump flow (e.g. from 4 to 2 l/min), the patient remains hemodynamically stable if cardiac load-responsiveness is sufficient (upper left). If cardiac load-responsiveness is blunted, the heart is not able to take over output, and venous volume will increase (upper right). Venous volume modulates the relation between pump speed (s) and flow ( $\mathrm{f}$ ) in the assisted circulation, which can be quantified by the DFI, i.e. the slope of the curve $\Delta \mathrm{f} / \Delta \mathrm{s}$. The DFI will not increase with diminished ELS flow when cardiac load-responsiveness is good (lower left), but will increase if cardiac load-responsiveness is decreased (lower right). CVP, central venous pressure; $A B P$, arterial blood pressure; RV, right ventricle; $L V$, left ventricle; SVR, systemic vascular resistance.

\section{Case Presentation}

We present the case of a patient with a severe myocardial infarction of the anterior wall. Despite urgent percutaneous coronary intervention and the institution of intra-aortic balloon support, the patient developed cardiogenic shock refractory to medical therapy. To stabilize the patient hemodynamically and provide adequate respiratory support, extracorporeal life support (ELS) was started with an assist flow of 4.2 1/min (Permanent Life Support, Maquet Cardiopulmonary AG, Hirrlingen, Germany). 


\section{Observations during cardiac reloading}

We show a less successful and a more successful outcome of on-pump cardiac loadresponsiveness. Cardiac reloading was performed by reducing bypass flow by approximately $4045 \%$ with concomitant inotropic support. DFI measurements were performed during full unloading (bypass flow $>41 / \mathrm{min}$ ), during reloading (bypass flow $\approx 21 / \mathrm{min}$ ), and again during subsequent full unloading (bypass flow $>41 / \mathrm{min}$ ). The number of DFI measurements for each level of support ranged from 5 to 15, and was 12 on average. The hemodynamic condition and corresponding mean DFI in the two events of reloading are presented in Figure 2.
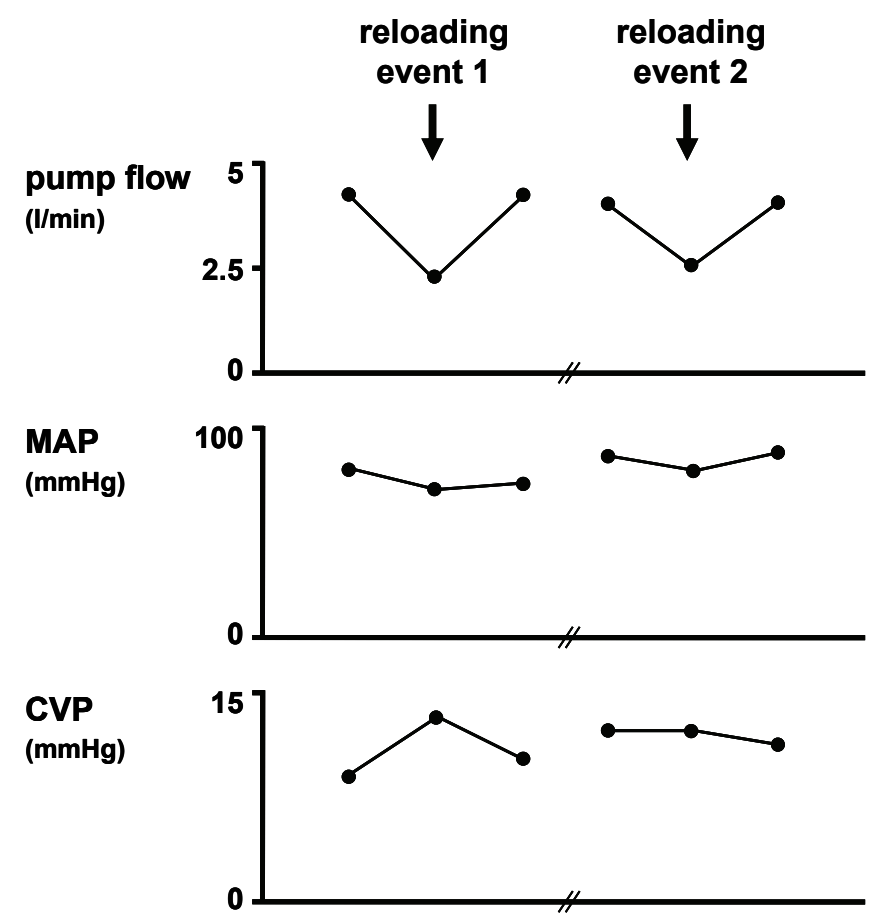

DFI
(ml/rot)

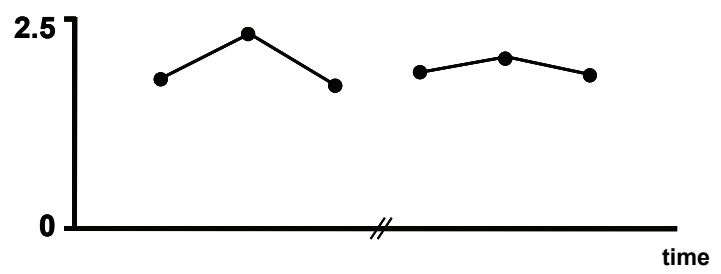

Figure 2 Hemodynamic parameters during cardiac reloading of the patient supported by extracorporeal life support. During the first event (left), DFI increased notably with diminished ELS flow. With the second event (right), DFI increased only marginally, suggesting increased cardiac loadresponsiveness. MAP, mean arterial pressure; CVP, central venous pressure DFI, dynamic filling index. 
As support flow was reduced during the first event on day 3, from 4.2 to $2.21 / \mathrm{min}$ (Figure 2, left) the patient became hemodynamically unstable despite intravenous dobutamine administration. TEE showed poor ventricular function. Radial artery pressure dropped (13\%) and central venous pressure rose $(44 \%)$. The DFI increased by $30 \%$, from $1.8 \pm 0.2$ to $2.3 \pm 0.2 \mathrm{ml} /$ rotation $(\mathrm{p}<0.001)$. To stabilize the patient again, flow was increased back to $4.1 \mathrm{l} / \mathrm{min}$. The DFI subsequently decreased by $35 \%$, returning to $1.7 \pm 0.2 \mathrm{ml} /$ rotation $(\mathrm{p}<0.001$ ). The second reloading event described here was started at day four (Figure 2, right). ELS flow was reduced from $4.0 \mathrm{l} / \mathrm{min}$ to $2.4 \mathrm{l} / \mathrm{min}$. Parallel TEE indicated improved ventricular wall contractility, and the patient remained hemodynamically stable with a dobutamine infusion set to $5 \mu \mathrm{g} / \mathrm{kg} / \mathrm{min}$. This time, the DFI did not change significantly $(\mathrm{p}>0.05)$. Although the DFI readings were not directly included in the evaluation of loadresponsiveness, they did independently and quantitatively confirm the increased cardiac load-responsiveness as judged from the TEE and pressure data. After the positive result of this stress test, pump flow was set back to $4.01 / \mathrm{min}$ to give the heart additional time to recover.

During the next four days, central venous and radial artery pressure indicated improved hemodynamic stability. An improvement of left ventricular function was confirmed by TEE. Based on the observation that cardiac load-responsiveness improved, further DFI measurements were stopped. After three more days of ELS, the patient was weaned from the extracorporeal system with the balloon pump (1:1) in place for additional afterload reduction, and on inotropic support (milrinone $25 \mu \mathrm{g} / \mathrm{kg} / \mathrm{h})$.

\section{DIscussion}

This report presents a patient assisted by extracorporeal life support (ELS) in which we demonstrated the use of the dynamic filling index for the quantitative assessment of cardiac load-responsiveness.

The common procedure to assess weanability from cardiac support consists of reduction of device flow, while intensivists, cardiac surgeons, cardiologists and perfusionists are consulted to confirm the rather subjective findings on cardiac recovery. This clinical routine is addressed by Schmid et al. [9], who state that weaning protocols are more exemption than routine, and that patient selection, diagnosis of adequate myocardial recovery, and timing of explant surgery are still unresolved. Pitsis et al. described intermittent unloading and loading of the heart in LVAD-supported patients [10], which can be regarded as cardiac muscle training prior to weaning. In such settings, TEE can be used to visualize cardiac function [4]. 
TEE, however, provides only a snap shot of the current situation, whereas pressure and cardiac output are measured continuously. In that context, Hoshi et al. described quantitative assessment of cardiac function by continuous measurement of the eccentric displacement of the centrifugal pump impeller [11]. Their measuring principle, however, can only be applied to fully magnetically levitated assist pumps. In all these cases, DFI measurement may support the TEE and hemodynamic observations by providing instant and quantitative information on cardiac pump function. Moreover, DFI measurement is by design applicable to all types of centrifugal pumps. When performed in a regular fashion, the DFI might even enable optimizing the actual weaning process.

In the case presented here, central venous pressure and DFI showed comparable changes in response to ELS reduction and indicated similar changes in cardiac loadresponsiveness. Central venous pressure measurement, however, depends on catheter placement, i.e. the location of pressure measurement (jugular vein, caval veins, atrium). When pressure is measured near the inlet of the venous ELS cannula, a change in central venous pressure read-out will, along with hydrostatic pressure, also reflect the rate of suction by the ELS circuit, rather than cardiac preload. Therefore, changes in central venous pressure may in some cases not reflect true changes in cardiac preload. The DFI is a measure of on-pump venous volume [7], and changes in DFI during reduced unloading (i.e. reduced ELS flow) could be a more reliable measure than central venous pressure. We previously found that DFI is more sensitive to small changes in venous volume than pump inlet pressure/central venous pressure [8]. Therefore, if a reliable central venous pressure is unavailable, DFI can be an alternative to assess cardiac load-responsiveness during ELS.

We are aware that we show only a single case in which the DFI was used to support the regular hemodynamic monitoring. More clinical investigations are necessary to establish the additional value of the DFI in the presence of regular ICU parameters. Considering the ease-of-use of DFI measurement and the promising findings in this patient, we intend to study regular DFI measurement in patients assisted by ELS, which, considering the incidence of ELS, will likely require a multicenter study.

\section{CONSENT}

Informed consent was obtained, and the use of patient data for this case report was approved by the medical ethical committee of the Maastricht University Medical Center. 


\section{ACKNOWLEDGMENT}

The authors would like to thank Mr Patrick R.G. Blyau and Mr Pieter Wortel for the open and stimulating discussions. 


\section{REFERENCES}

1. Cooper DS, Jacobs JP, Moore L, Stock A, Gaynor JW, Chancy T, Parpard M, Griffin DA, Owens T, Checchia PA, Thiagarajan RR, Spray TL, Ravishankar C. Cardiac extracorporeal life support: state of the art in 2007. Cardiology in the young. 2007;17 Suppl 2:104-15.

2. Kahn J, Muller H, Marte W, Rehak P, Wasler A, Prenner G, Tscheliessnigg K. Establishing extracorporeal membrane oxygenation in a university clinic: case series. Journal of cardiothoracic and vascular anesthesia. 2007;21:384-7.

3. Bartlett RH, Roloff DW, Custer JR, Younger JG, Hirschl RB. Extracorporeal life support: the University of Michigan experience. Jama. 2000;283:904-8.

4. Salem R, Vallee F, Rusca M, Mebazaa A. Hemodynamic monitoring by echocardiography in the ICU: the role of the new echo techniques. Current opinion in critical care. 2008;14:561-8.

5. Hadian M, Pinsky MR. Functional hemodynamic monitoring. Current opinion in critical care. 2007;13:318-23.

6. Simons AP, Reesink KD, Lance MD, van der Nagel $\mathrm{T}$, van der Veen $\mathrm{FH}$, Weerwind PW, Maessen JG. Reserve-driven flow control for extracorporeal life support: proof of principle. Perfusion. 2010;25:25-9.

7. Simons AP, Reesink KD, Lance MD, van der Veen FH, de Jong DS, Weerwind PW, Maessen JG. Dynamic filling index: a novel parameter to monitor circulatory filling during minimized extracorporeal bypass. Eur J Cardiothorac Surg. 2009;36:330-4.

8. Simons AP, Reesink KD, Molegraaf GV, van der Nagel T, de Jong MMJ, Severdija EE, de Jong DS, van der Veen FH, Maessen JG. An in vitro and in vivo study of the detection and reversal of venous collapse during extracorporeal life support. Artif Organs. 2007;31:152-9.

9. Schmid C, Etz C, Welp H, Rothenburger M, Reinecke H, Schafers M, Schmidt C, Scheld HH. Clinical situations demanding weaning from long-term ventricular assist devices. Eur J Cardiothorac Surg. 2004;26:730-5.

10. Pitsis AA, Visouli AN, Ninios V, Bougioukas G, Filippatos G, Kremastinos D, Burkhoff D, Long JW. Elective bridging to recovery after repair: the surgical approach to ventricular reverse remodeling. Artif Organs. 2008;32:730-5.

11. Hoshi H, Asama J, Hara C, Hijikata W, Shinshi T, Shimokohbe A, Takatani S. Detection of left ventricle function from a magnetically levitated impeller behavior. Artif Organs. 2006;30:37783. 



\section{CHAPTER 7}

\section{LETTER TO THE EDITOR}

letter in response to an original publication

+ reply from the authors

+ appendix

\section{Published as:}

Simons AP. June 2008 issue: Jesus Herreros from the University Hospital of Navarra, Pamplona, Spain. Letter to the editor. Artif Organs. 2008;32:1000-1; author reply 1-2. 


\section{To the Editor:}

In your June issue 2008 of the journal, I read the interesting article of Jesús Herreros from the University Hospital of Navarra, Pamplona, Spain [1] (Abstract and figures in Appendix). In the article, he and his colleagues introduce a novel method to provide partial pulsatile flow. They redesigned a centrifugal blood pump by implementing an inflatable membrane into the pump housing. As shown in Figs. 1e and $2 \mathrm{a}$, the rotating cone provides a continuous flow and pressure signal, which is changed pulsatile by inflation and deflation of the membrane.

Some groups found conflicting and insufficient evidence for the benefits of pulsatile flow, whereas others claim pulsatile flow to improve organ perfusion, perioperative hemodynamics, and patient outcome [2]. As a result, 'to pulse or not to pulse' remains an ongoing topic of discussion. Nevertheless, a relationship has been found between organ perfusion and energy delivered by pulsatile flow, described in terms of surplus hemodynamic energy (SHE) [3]. As expected and nicely demonstrated by the results of Herreros et al., the pulses generated with their pump enabled the addition of SHE to the continuous flow delivered by their centrifugal pump. The pulse generated travels down the pump outlet line, and is detected by the pressure and flow sensors downstream. However, due to the non-occlusive construction principle of the pump, I expect the pulses to travel upstream the pump inlet line as well.

The mock circulation described in Fig. 1e mimics an extracorporeal bypass circuit featuring a venous reservoir. In this configuration, the pulse traveling upstream ends in this reservoir. However, in a bypass circuit without a venous reservoir, as used in extracorporeal life support, this upstream pulse ends in the venous system. Also a ventricular assist, as mentioned in their discussion section, lacks such a reservoir, and the upstream traveling pulse induces a pulsatile load on the weakened heart. Therefore, I have some doubts about the application of such a pulsatile pump in bypass circuits without a buffering element in the suction line.

Pulsatile flow generation by acceleration and deceleration of the centrifugal pump impeller requires pump preload to be sufficient for high flow peaks. In extracorporeal bypass circuits in which the pump drains from a venous reservoir, this preload is most likely available. Bypass circuits that lack a venous reservoir directly drain from the atrium and large veins. During their application, preload is limited to the intravascular volume, which may proof insufficient during flow with a high pulsatile character. In such critical low preload condition, the drainage cannula aspirates the vessel wall, resulting in impeded drainage and reduced bypass flow. The novel centrifugal pump has the advantage not to enforce drainage during pulsation. Therefore, this new pump design could be a promising technique when pulsatile flow is preferred but pump preload is limited. However, it needs 
further development to reduce backflow pulsations, as mentioned in the previous paragraph.

The oxygenator located in the pump outlet line increases the circuit's hydraulic resistance and compliance. In a current study at our hospital, we found evidence that the oxygenator can absorb up to $40 \%$ of the pulse created. In the article, SHE values were calculated using the pressure and flow measured downstream the oxygenator. In doing so, the values represent the SHE delivered to the patient, but not the SHE actually created by the pump. In order to present the actual SHE created by the pump, thus independent of the extracorporeal circuit connected, I suggest the use of flow and pressure signals measured directly at the pump outlet. Although this does not take into account the pressure and flow at the pump inlet, I still expect SHE values measured at the pump outlet to increase by at least $60 \%$.

During pulsatile pump operation, the distance between the pump housing and the rotating cone changes continuously. The authors claim the membrane not to affect pump performance. I assume the performance tests have been performed with the membrane halted in a position in which its shape and distance to the pump impeller are close to that of the original pump housing. During membrane deflation, however, the gap between membrane and cone increases, which may affect pump internal recirculation and washout. Washout remains an important issue in blood pump engineering, as flow regurgitation and resulting stagnant areas cause blood thrombus formation, and should be avoided.

I'm looking forward to future work of the group of Herreros et al. showing further pump development and hemocompatibility tests. I wish him and his team success in this and future research.

Regards,

Antoine P. Simons, MSc

Maastricht University Medical Center

Department of Cardiothoracic Surgery

Maastricht, the Netherlands

\section{References}

1. Herreros J, Berjano EJ, Sales-Nebot L, Mas P, Calvo I, Mastrobuoni S, Merce S. A new method of providing pulsatile flow in a centrifugal pump: assessment of pulsatility using a mock circulatory system. Artif Organs. 2008;32:490-4.

2. Alghamdi AA, Latter DA. Pulsatile versus nonpulsatile cardiopulmonary bypass flow: an evidence-based approach. Journal of cardiac surgery. 2006;21:347-54.

3. Undar A, Masai T, Beyer EA, Goddard-Finegold J, McGarry MC, Fraser CD, Jr. Pediatric physiologic pulsatile pump enhances cerebral and renal blood flow during and after cardiopulmonary bypass. Artif Organs. 2002;26:919-23. 


\section{RePly fROM THE AUthors}

\section{To the Editor:}

We appreciate the comments by Dr. Simons regarding our article that was published in the June 2008 issue of Artificial Organs, especially his constructive observations about the potential use of the new pump as a ventricular assistance device.

First, Dr. Simons calls attention to the possibility that, due to the non-occlusive construction principle of the pump, the pulse generated travels not only down the pump outlet line, but also upstream the pump inlet line. Although this does seem to be the case, we did not characterize the reverse pulsatile flow. However, as Dr. Simons has indicated, we think that the upstream reverse pulse ends up in the reservoir. We agree with Dr. Simons' comment regarding the possible application of our device to provide ventricular assistance; however, we also consider that using the pump without a buffering element in the suction line (such as a small reservoir) could imply risks for the patient's heart.

Secondly, although the surplus hemodynamic energy (SHE) values measured directly at the pump outlet can be used to characterize the pump regardless of the extracorporeal circuit utilized, we decided to assess the SHE downstream of the oxygenator (i.e., SHE delivered to the patient) in order to get a better idea of the hydraulic effect of the oxygenator on the pulse. Moreover, since our results were compared with those obtained by a truly pulsatile pump as a reference, we were also able to compare the effect of the hydraulic resistance and compliance of the oxygenator on each type of pulsatile flow.

Finally, we claimed that the membrane does not affect pump performance from the hydraulic point of view. Our results were obtained, as Dr. Simons states, with the membrane explicitly stopped in an arrangement (shape and distance to the pump housing) similar to that of a conventional centrifugal pump. The pressureflow characteristics of the new pump were only assessed in comparison with a conventional centrifugal pump. Consequently, we did not evaluate the pump's internal recirculation and washout. As Dr. Simons points out, this is important, as flow regurgitation and the resulting stagnant areas could cause blood thrombus formation. On this point, we conducted an experimental study on pigs employing the new pump as extracorporeal bypass circuit. The results, not yet published (1), show that neither platelet count nor platelet function (assessed by the closure time CT with the PFA-100 (2)) was significantly altered by the new pump during extracorporeal circulation. Because it is known that the stagnant areas induce the alteration of platelet function and blood thrombus formation (3), the preliminary results suggest that the new pump provides suitable recirculation and washout. Once more, we thank Dr. Simons for his interesting observations regarding our study. 
Enrique J. Berjano, PhD

Universitat Politècnica de València

Electronic Engineering Department

València, Spain

\section{References}

1. Herreros J, Ubilla M, Berjano EJ, Vila-Nuñez JE, Páramo JA, Sola J, Mercé S. In vivo assessment of a new method of pulsatile perfusion based on a centrifugal pump. Artificial Organs (in press).

2. Herreros J, Berjano EJ, Mas P, Padros C, Sales-Nebot L, Vlaanderen W, Diaz P, Paramo JA, Rabago G, Merce S. Platelet dysfunction in cardiopulmonary bypass: an experimental comparative study between a centrifugal and a new pulsatile pump. Int J Artif Organs. 2003;26:1086-94.

3. Unger F, Olsen DB, Oster H, Kolff WJ. Material and design factors in thromboembolization in total artificial heart recipients living 100-2,000 hours. Eur Surg Res. 1976;8:105-16. 


\section{APPENDIX}

To help understand the Letter to the Editor (Chapter 7), this section contains the abstract and figures of the publication references are made to.

From: Herreros J, Berjano EJ, Sales-Nebot L, Mas P, Calvo I, Mastrobuoni S, Merce S. A new method of providing pulsatile flow in a centrifugal pump: assessment of pulsatility using a mock circulatory system. Artif Organs. 2008;32:490-4.

\section{Abstract}

Previous studies have demonstrated the potential advantages of pulsatile flow as compared with continuous flow. However, to date, physiologic pumps have been technically complex and their application has therefore remained in the experimental field. We have developed a new type of centrifugal pump, which can provide pulsatile as well as continuous flow. The inner wall of a centrifugal pump is pulsed by means of a flexible membrane, which can be accurately controlled by means of either a hydraulic or pneumatic driver. The aim of this study was to assess the hydraulic behavior of the new pump in terms of surplus hemodynamic energy (SHE). We conducted experiments using a mock circulatory system including a membrane oxygenator. No differences were found in the pressure-flow characteristics between the new pump and a conventional centrifugal pump, suggesting that the inclusion of the flexible membrane does not alter hydraulic performance. The value of SHE rose when systolic volume was increased. However, SHE dropped when the percentage of ejection time was reduced and also when the continuous flow (programmed by the centrifugal console) increased. Mean flow matched well with the continuous flow set by the centrifugal console, that is, the pulsatile component of the flow was exclusively controlled by the pulsatile console, and was therefore independent of the continuous flow programmed by the centrifugal console. The pulsatility of the new pump was $\sim 25 \%$ of that created with a truly pulsatile pump. 


\section{Figures}
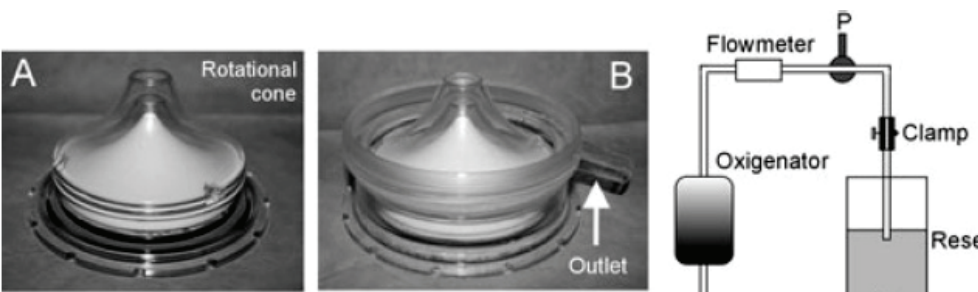

$E$
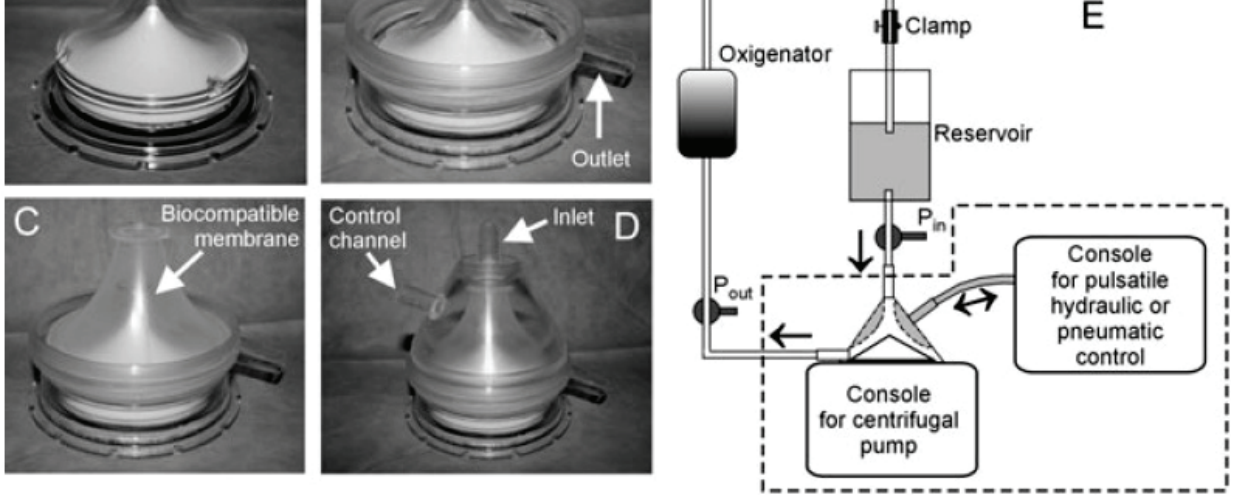

Figure 1 The new pump for providing pulsatile flow from a centrifugal pump. The idea is based on a centrifugal pump provided with a flexible silicone membrane. First, the top part of a conventional centrifugal pump was removed, leaving only the rotational cone (A). This cone was joined to a custom-made methacrylate piece, which included an outlet (B). A custom-made flexible silicone membrane was attached to the custom piece (C). Finally, another custom-made methacrylate element including an inlet and control channel was attached to the top part (D). A hydraulic circuit (E) was used to test the new pulsatile pump. The dashed-line box represents the new centrifugalbased pump (driven by a centrifugal console) and an internal flexible membrane driven pneumatically or hydraulically by a second console.
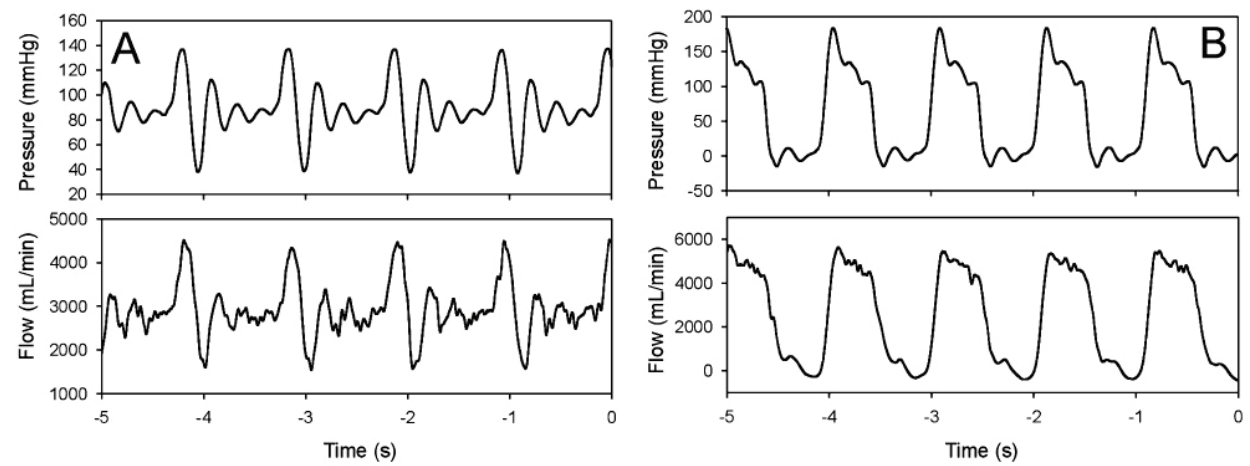

Figure 2 A: typical pressure and flow waveforms obtained from the new pump under test, showing a positive component followed by the equivalent negative component (the mean flow $=3 \mathrm{l} / \mathrm{min}$ exactly matched the continuous flow set by the centrifugal console). B: typical pressure and flow waveforms from the Physioheart pulsatile pump (stroke volume of $40 \mathrm{ml}$ and pumping frequency of $60 \mathrm{bpm})$. 

CHAPTER 8

GENERAL DISCUSSION 
Extracorporeal life support (ELS) systems provide mechanical cardiopulmonary assistance. They relieve the heart from hemodynamic load while organ perfusion is maintained [1-4]. With veno-arterial ELS, intravascular volume is directly drawn from the venous circulation, typically by a centrifugal blood pump which then pumps the blood through an artificial lung into the arterial system. Changes in venous intravascular volume, however, directly affect venous drainage and thereby ELS flow. Automated control of bypass flow to maintain cardiopulmonary support in different hemodynamic conditions could be helpful. Unfortunately, currently available control schemes for centrifugal pumps are not suitable for ELS. For instance, the typical flow servo aims at maintaining a preset bypass flow by coupling pump speed to pump flow: pump speed is increased to compensate for a decreasing flow, and vice versa. Of course, increasing pump speed while the volume available for drainage is insufficient will actually lead to a progressive, potentially steep reduction in bypass flow. This problem is a direct result of the 'demand-driven' objective in the control scheme, i.e. to maintain output at a preset level. This thesis has introduced a reserve-driven centrifugal pump control scheme. The controller uses a dynamic approach to measure drainable volume and calculates the dynamic filling index, a novel parameter which acts as a marker of circulatory filling during ELS. Depending on the dynamic filling index and based on insight into ELS-patient interaction, 'smart' pump interventions are used to maintain a maximum level of support in low filling conditions. Additionally, we found that during weaning from ELS the dynamic filling index can be used to detect changes in cardiac pump reserve capacity.

\section{Monitoring ELS flow requires monitoring patient volume}

Under the variable conditions in which ELS systems are operated, drainable venous volume can be diminished, for instance due to peripheral edema or post-operative bleeding when hemostasis has not yet stabilized [5]. As a result of the limited sensitivity of standard hemodynamic assessment methods the reduction in drainable volume may initially remain unnoticed [6-8]. Also acute complications like cardiac tamponade, tension hemothorax, tension pneumothorax, and elevated intrathoracic pressures as a result of mechanical ventilation can negatively affect drainable venous volume [9-12]. All may greatly increase extravascular pressure within the thorax. When extravascular pressure exceeds intravascular pressure at the drainage site, the large veins collapse [13], the drainable intravascular volume decreases severely and ELS flow will diminish progressively (Chapter 2).

In contrast to hemodynamic monitoring methods using static (single-point) measurement of patient and pump related parameters, dynamic measurement methods assess system response and have shown superior in patient monitoring 
[14-16]. The technique of measuring the dynamic filling index (DFI) employs such a dynamic approach (Figure 1), as it induces small pump speed alterations and measures the resultant change in bypass flow. Hereby, DFI measurement proved more sensitive to changing drainable intravascular venous volume than the regular (static) monitoring techniques (Chapters 2 and 4). Therefore, DFI could be a valuable additional tool in monitoring patient filling and drainage reserve capacity. Moreover, DFI may guide volume administration during long-term assistance to prevent developing loss of ELS flow.
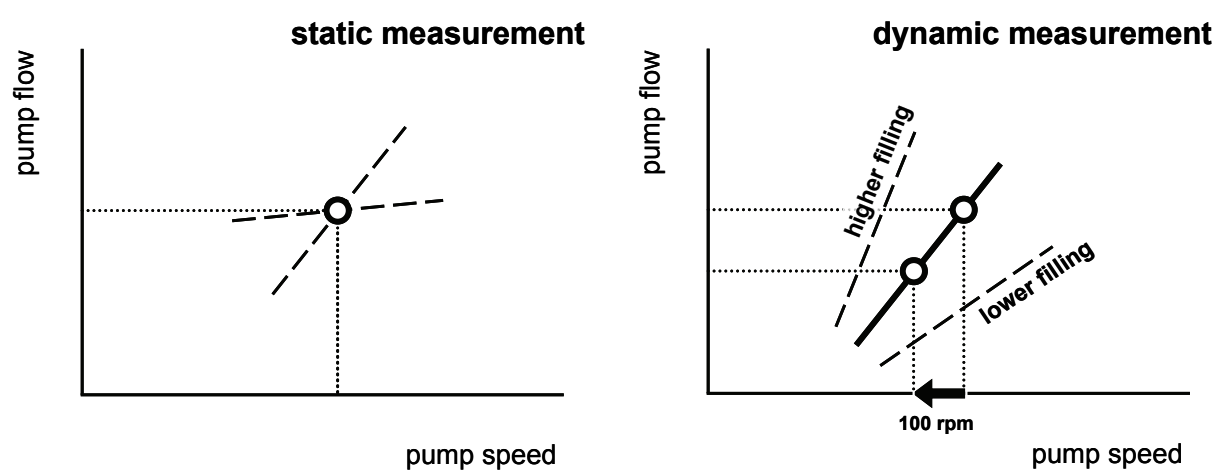

Figure 1 The static assessment of pump related parameters for ELS monitoring provides the level of support flow at a given pump speed (left). The relationship between pump speed and pump flow, however, is modulated by circulatory filling, and remains unrevealed using the static approach (dashed lines). In contrast to the static, 'single-point' method, the dynamic approach considers the relationship between pump speed and pump flow, and can thereby directly assess drainable volume (right).

The impact of the DFI assessment method itself should not affect the patient's condition. This means that the duration and amplitude of the changes in pump speed should be as small as possible to prevent hypoperfusion, while still being large enough to highlight flow changes from the 'normal' fluctuations (noise) in the flow signal, i.e. provide a sufficient signal-to-noise ratio. There is a trade-off between signal acquisition and time needed for DFI measurement. Although this thesis did not investigate the effect of time or amplitude in detail, it clearly showed the power of DFI as a sensitive tool for hemodynamic monitoring during ELS (Chapters 2 and 4). Further work on organ perfusion in relation to timing and amplitude parameters of DFI measurement, however, should be performed in future studies. 


\section{Smart pump readjustment restores the balance}

The previous section discussed examples of gradual and acute loss of ELS flow resulting from reduced drainable venous intravascular volume, needing timely intervention. The decrease in flow is the result of disproportionate drainage, which boils down to an excessive pump speed for the present pump preload. The imbalance between drainable volume available and desired pump flow can be restored by administering volume intravenously, and its effect can be verified using the DFI. Alternatively, well-controlled pump readjustment can temporarily restore the balance as well, a tactic employed in left ventricular assistance device management $[17,18]$. Also with ELS such 'smart' speed adjustment can be helpful when pump flow is reduced due to excessive drainage and resultant vessel collapse. A multistep speed intervention (Figure 2) can produce an increase in pump flow at a lower pump speed (Chapter 2). This sequence of events is then indicative of resolved vessel collapse and a (temporarily) restored preload-drainage balance.
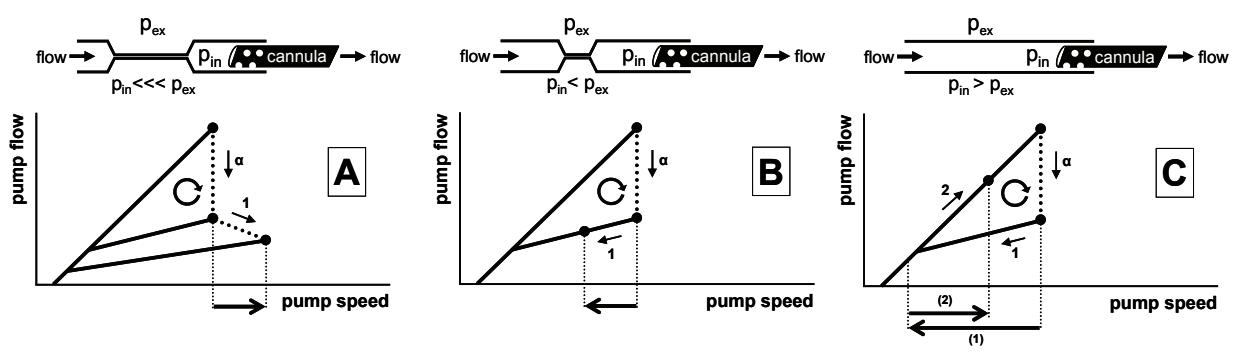

Figure 2 Schematic representations of the non-linear flow-speed relationship in a centrifugal pump based extracorporeal life support system and the vessel condition after pump speed readjustment. The arrows 1 and 2 represent pump speed readjustments in order of appearance to compensate for decreased pump flow $(\alpha)$. Panel A: Classic flow servo control for centrifugal pumps would increase pump speed, which aggravates vessel collapse and decreases pump flow more. The imbalance between drainable volume and desired pump flow persists. Panel B: Pump control constrained by a preset pump inlet pressure reduces pump speed. The simple speed decrease does not necessarily change the imbalance and pump flow remains insufficient. Panel C: The 2-step speed intervention restores the balance between drainable volume available and desired support flow. The multi-step pump adjustment resolves vessel collapse and results in a higher pump flow at a lower pump speed.

As with DFI measurement, also a multi-step speed adaptation for restoring drainage has limitations in duration and amplitude. A speed decrease lasting too long may extent the duration of low support and may pose the risk of hypoperfusion. In contrast, if the initial speed reduction is too short or too small, it may prove insufficient in re-opening the collapsed vessel and restoring the balance. This thesis showed the mechanism behind successful multi-step speed adaption to restore 
drainage (Chapter 2), but the procedure's parameters need further investigation to establish clinical applicability and safety.

\section{Reserve-driven ELS flow control}

A pump control scheme combining DFI measurement (Chapter 4) and multi-step speed adaptation (Chapter 2) results in a reserve-driven ELS flow control scheme. By assessing the venous volume and adjusting pump speed to that volume, the ELS flow is adapted to the intravascular volume available, without attempting to pump blind a desired flow rate. DFI assesses the balance between available drainable volume and desired flow, whereas pump speed is decreased using a multi-step approach whenever an imbalance is detected. In an animal experimental setting, this control scheme has proven successful in maintaining ELS during a condition of substantially reduced drainable venous intravascular volume (Chapter 5). Although the 'restored' bypass flow after a multi-step speed adaptation may be insufficient in providing adequate circulatory support, the re-established flow is optimal in the sense that it is the maximum available at that instant and under the prevailing conditions. Therefore, reserve-driven flow control may serve as a first emergency backup during critical loss of drainable volume. Subsequently, volume infusion and possibly surgical intervention should further reduce the extent of hypoperfusion.

\section{Cannula design}

Venous drainage during cardiopulmonary support starts with the venous cannula, or more specifically, at the venous cannula tip. Both proper cannula placement and special cannula tip designs affect drainage. Atrial tip placement of a femoral cannula results in higher rates of drainage flow [19] and enhanced tip design of cannulae for central cannulation can improve drainage flow during (pending) cannula inlet obstruction (Chapter 3). In contrast to the cannulae intended for central cannulation, of which the tip designs vary considerably (Figure 3), current design of femoral venous cannulae aims at smooth outer surfaces and a large inner lumen with multiple side holes. The smooth surface facilitates easy insertion and limits vessel damage during cannula positioning. The large lumen reduces drainage resistance and the holes provide drainage from the caval veins and atrium. Also in situ shape-changing cannulae have proven successful in optimizing drainage flow [20-22]. Combined with 'smart' adaptive drainage as decribed in the previous section, such shape-changing cannulae can be expected to improve drainage and support flow during the various hemodynamic conditions in which ELS is applied [1-4]. 


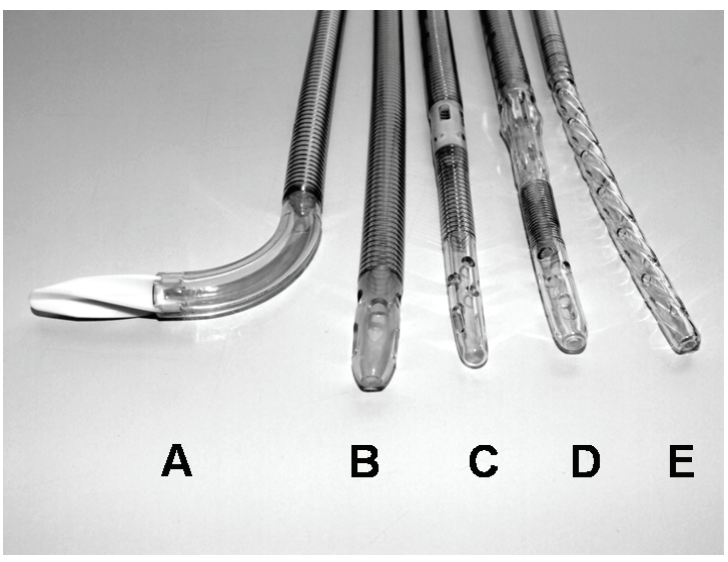

Figure 3 Five venous cannulae for proximal cannulation featuring different tip designs. A: swirled and grooved. B: single stage lighthouse tip. C: dual stage with lighthouse tip. D: three stage with protruding round-cage structure and light house tip. E: swirled and grooved multi-stage with one main entrance hole at the tip.

Although enhanced cannula design has proven valuable to drainage, it should be stressed that even the most sophisticated construction can not prevent a vessel from collapsing. A decreasing vessel diameter is the result of disproportionate drainage which can only be resolved successfully by volume infusion or decreased suction force.

\section{Monitoring volume during weaning from ELS}

The current strategy of weaning from ELS is to progressively reload the heart by gradually reducing support flow. Meanwhile, the hemodynamic response of the patient is carefully monitored [23]. Transesophageal echocardiography (TEE), cardiac output measurement and measurement of pulmonary, radial artery and central venous pressure provide indirect information on cardiac pump function [15, 24-29]. Weaning still remains a relatively subjective matter which often relies on preconceived protocols, if any, and is largely based on trial-and-error and only limited data on actual cardiac function [30].

During weaning from ELS, an increase in venous volume is likely to be indicative of limited cardiac load-responsiveness. With an insufficient Frank-Starling response the heart is not able to deal with the increasing preload given by diminished ELS flow, resulting in venous congestion. As illustrated in Chapter 6, DFI measurement during weaning can provide a measure for changes in cardiac pump function by reflecting the degree by which the heart is able to respond to increasing preload and take over output. As a result, DFI could augment the array of monitoring techniques currently used during weaning [23]. Continuous DFI measurement may provide the possibility to fine-tune the weaning procedure to the individual patient. By doing so, DFI could help in the development of adaptive ELS systems which assess actual cardiac pump reserve capacity and auto-adjust the level of 
support to promote cardiac recovery and to keep the duration of support as short as possible.

\section{Flow conditions}

Pulsatile bypass flow is intended to mimic fysiologic flow patterns generated by the heart, but still, "to pulse or not to pulse" remains an ongoing subject of discussion [31-37]. With ELS, the generation of pulsatile flow comes with limitations of which two are described here. Moreover, pulsatile ELS could negatively affect DFI measurement.

In minimized circuits, i.e. without venous reservoir, pump preload is given by the intravascular venous volume which will be sufficient to provide a continuous drainage flow of for instance $5 \mathrm{l} / \mathrm{min}$. With pulsatile flow, flow peaks can exceed $10 \mathrm{l} / \mathrm{min}$ while mean flow is maintained at $5 \mathrm{l} / \mathrm{min}$ [38]. For the flow peaks the instantaneous drainable volume is likely to prove insufficient. As a result, pump systole by acceleration of the pump rotor results in an imbalance between the desired pump flow and the venous volume available during pump systole. Subsequently, the vessel collapses and the cannula inlet holes become obstructed, pump stroke volume reduces and mean flow decreases (Figure 4). Additional DFI measurement would indicate insufficient patient filling, although venous volume would prove sufficient for a mean support flow of $5 \mathrm{l} / \mathrm{min}$. Herreros et. al introduced a possible method for pulsatile flow using a centrifugal pump without upspinning of the rotor, thereby reducing excessive drainage [39]. Applied to ELS, their technique allows for the delivery of surplus hemodynamic energy to the patient's vascular system [40] while the pulsatile flow is likely to remain balanced with sustained ELS (Chapter 7).
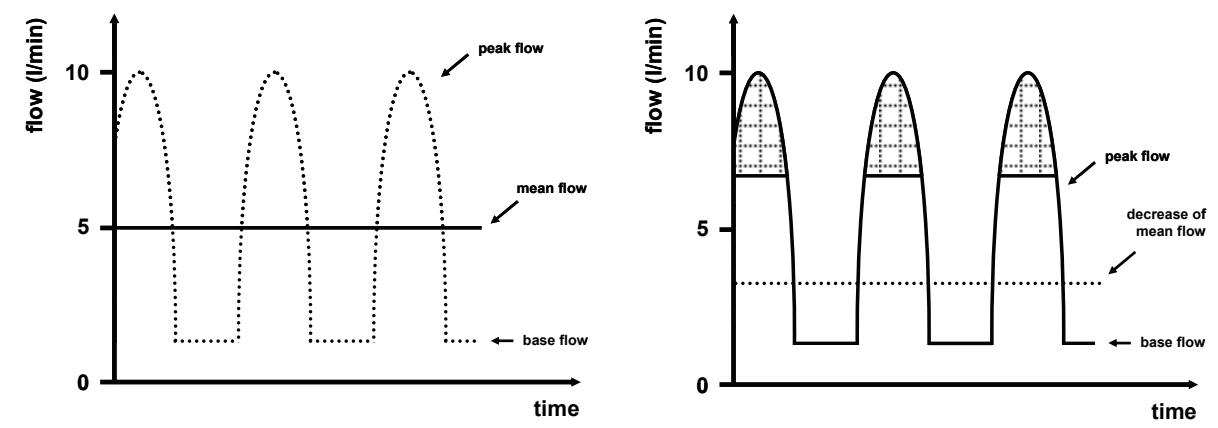

Figure 4 Although pump preload can be sufficient for a continuous pump flow of e.g. $51 / \mathrm{min}$ (left), the instantaneous drainable venous intravascular volume may prove insufficient for the generation of peak flows of $10 \mathrm{l} / \mathrm{min}$. As a result, the stroke volume is reduced (shaded area), ultimately leading to a decrease of mean pump flow (right). 
With high peak flows during pulsatile flow, the total pressure drops of the circuit components downstream the pump can be higher than 1,000 $\mathrm{mmHg}$ [38]. The maximum inducible pump head of a centrifugal blood pump, however, remains far below 1,000 mmHg [41, 42]. Subsequently, with numerous high-resistive circuit components downstream a pulsatile centrifugal pump the actual induced pump outlet pressure during pump systole may prove insufficient to create flow peaks of sufficient magnitude. As a result, the mean bypass flow decreases although pump preload may prove sufficient (Figure 5). As a result of a reduced mean flow, DFI measurement would falsely indicate low filling. Therefore, a pulsatile centrifugal pump should preferably be used with low-resistant circuit components to prevent non-filling related hypoperfusion during ELS.
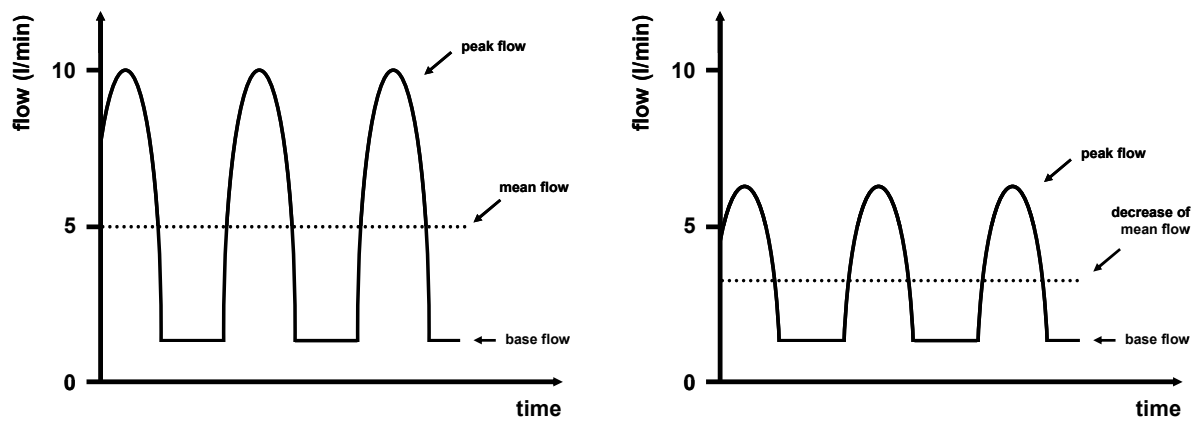

Figure 5 During pulsatile flow, mean flow is given by adding consecutive peak flows to the base flow (left). Pulsating while pump power proves insufficient to achieve peak flow results in a decrease of mean pump flow (right).

\section{What ELSe?}

Reserve-driven pump control based on the assessment of venous volume has shown to decrease the extend and duration of low filling related hypoperfusion (Chapters 2, 4 and 5), whereas enhanced cannula tip design has shown valuable in maintaining drainage flow during varying hemodynamic conditions (Chapter 3). Moreover, an ELS system that senses cardiac pump reserve capacity (Chapter 6) and adapts pulsatile support (Chapter 7) to the level needed would be a valuable first step towards a whole new generation of 'intelligent' cardiopulmonary assist devices. In that context, combining ELS with endotoxine filtration [43-45] would move ELS from pure clinical cardiopulmonary support towards ELS as a therapeutic treatment. Such treatment would open doors to a larger spectrum of patients that may benefit from ELS, now and in the future. 


\section{REFERENCES}

1. Bartlett RH, Roloff DW, Custer JR, Younger JG, Hirschl RB. Extracorporeal life support: the University of Michigan experience. Jama. 2000;283:904-8.

2. Cooper DS, Jacobs JP, Moore L, Stock A, Gaynor JW, Chancy T, Parpard M, Griffin DA, Owens T, Checchia PA, Thiagarajan RR, Spray TL, Ravishankar C. Cardiac extracorporeal life support: state of the art in 2007. Cardiology in the young. 2007;17 Suppl 2:104-15.

3. Formica F, Avalli L, Martino A, Maggioni E, Muratore M, Ferro O, Pesenti A, Paolini G. Extracorporeal membrane oxygenation with a poly-methylpentene oxygenator (Quadrox D). The experience of a single Italian centre in adult patients with refractory cardiogenic shock. Asaio J. 2008;54:89-94.

4. Fromes Y, Gaillard D, Ponzio O, Chauffert M, Gerhardt MF, Deleuze P, Bical OM. Reduction of the inflammatory response following coronary bypass grafting with total minimal extracorporeal circulation. Eur J Cardiothorac Surg. 2002;22:527-33.

5. Stulak JM, Dearani JA, Burkhart HM, Barnes RD, Scott PD, Schears GJ. ECMO Cannulation Controversies and Complications. Seminars in cardiothoracic and vascular anesthesia. 2009.

6. Androne AS, Hryniewicz K, Hudaihed A, Mancini D, Lamanca J, Katz SD. Relation of unrecognized hypervolemia in chronic heart failure to clinical status, hemodynamics, and patient outcomes. The American journal of cardiology. 2004;93:1254-9.

7. Lowell JA, Schifferdecker C, Driscoll DF, Benotti PN, Bistrian BR. Postoperative fluid overload: not a benign problem. Critical care medicine. 1990;18:728-33.

8. Magder S. Central venous pressure monitoring. Current opinion in critical care. 2006;12:219-27.

9. Hulyalkar AR, Watkins L, Reitz BA, Casella ES. Transesophageal echocardiographic diagnosis of covert cardiac tamponade during extracorporeal membrane oxygenation in an adult. J Thorac Cardiovasc Surg. 1992;104:1756-7.

10. Kesecioglu J, Telci L, Esen F, Akpir K, Tutuncu AS, Denkel T, Erdmann W, Lachmann B. Respiratory and haemodynamic effects of conventional volume controlled PEEP ventilation, pressure regulated volume controlled ventilation and low frequency positive pressure ventilation with extracorporeal carbon dioxide removal in pigs with acute ARDS. Acta anaesthesiologica Scandinavica. 1994;38:879-84.

11. Kurian MS, Reynolds ER, Humes RA, Klein MD. Cardiac tamponade caused by serous pericardial effusion in patients on extracorporeal membrane oxygenation. Journal of pediatric surgery. 1999;34:1311-4.

12. Zwischenberger JB, Cilley RE, Hirschl RB, Heiss KF, Conti VR, Bartlett RH. Life-threatening intrathoracic complications during treatment with extracorporeal membrane oxygenation. Journal of pediatric surgery. 1988;23:599-604.

13. Amoore JN, Santamore WP. Venous collapse and the respiratory variability in systemic venous return. Cardiovasc Res. 1994;28:472-9.

14. Pinsky MR, Payen D. Functional hemodynamic monitoring. Critical care (London, England). 2005;9:566-72.

15. Pinsky MR, Teboul JL. Assessment of indices of preload and volume responsiveness. Current opinion in critical care. 2005;11:235-9.

16. Vincent J-L. Yearbook of Intensive Care and Emergency Medicine. Berlin, Heidelberg, New York: Springer-Verlag 2007.

17. Ohuchi K, Kikugawa D, Takahashi K, Uemura M, Nakamura M, Murakami T, Sakamoto T, Takatani S. Control strategy for rotary blood pumps. Artif Organs. 2001;25:366-70. 
18. Vollkron M, Schima H, Huber L, Benkowski R, Morello G, Wieselthaler G. Development of a reliable automatic speed control system for rotary blood pumps. J Heart Lung Transplant. 2005;24:1878-85.

19. Kurusz M, Deyo DJ, Sholar AD, Tao W, Zwischenberger JB. Laboratory testing of femoral venous cannulae: effect of size, position and negative pressure on flow. Perfusion. 1999;14:37987.

20. Jegger D, Mueller X, Mucciolo G, Mucciolo A, Boone Y, Seigneul I, Horisberger J, von Segesser LK. A new expandable cannula to increase venous return during peripheral access cardiopulmonary bypass surgery. Int J Artif Organs. 2002;25:136-40.

21. von Segesser LK, Jegger D, Mucciolo G, Tozzi P, Mucciolo A, Delay D, Mallabiabarrena I, Horisberger J. The Smartcanula: a new tool for remote access perfusion in limited access cardiac surgery. Heart Surg Forum. 2005;8:E241-5.

22. von Segesser LK, Kalejs M, Ferrari E, Bommeli S, Maunz O, Horisberger J, Tozzi P. Superior flow for bridge to life with self-expanding venous cannulas. Eur J Cardiothorac Surg. 2009;36:665-9.

23. Vakamudi M. Weaning from cardiopulmonary bypass: problems and remedies. Annals of cardiac anaesthesia. 2004;7:178-85.

24. Berridge JC, Warring-Davies K, Bland JM, Quinn AC. A new, minimally invasive technique for measuring cardiac index: clinical comparison of continuous cardiac dynamic monitoring and pulmonary artery catheter methods. Anaesthesia. 2009;64:961-7.

25. Cottis R, Magee N, Higgins DJ. Haemodynamic monitoring with pulse-induced contour cardiac output (PiCCO) in critical care. Intensive Crit Care Nurs. 2003;19:301-7.

26. Hofer CK, Senn A, Weibel L, Zollinger A. Assessment of stroke volume variation for prediction of fluid responsiveness using the modified FloTrac and PiCCOplus system. Critical care (London, England). 2008;12:R82.

27. Reuter DA, Felbinger TW, Schmidt C, Kilger E, Goedje O, Lamm P, Goetz AE. Stroke volume variations for assessment of cardiac responsiveness to volume loading in mechanically ventilated patients after cardiac surgery. Intensive Care Med. 2002;28:392-8.

28. Reuter DA, Kirchner A, Felbinger TW, Weis FC, Kilger E, Lamm P, Goetz AE. Usefulness of left ventricular stroke volume variation to assess fluid responsiveness in patients with reduced cardiac function. Critical care medicine. 2003;31:1399-404.

29. Salem R, Vallee F, Rusca M, Mebazaa A. Hemodynamic monitoring by echocardiography in the ICU: the role of the new echo techniques. Current opinion in critical care. 2008;14:561-8.

30. Schmid C, Etz C, Welp H, Rothenburger M, Reinecke H, Schafers M, Schmidt C, Scheld HH. Clinical situations demanding weaning from long-term ventricular assist devices. Eur J Cardiothorac Surg. 2004;26:730-5.

31. Alghamdi AA, Latter DA. Pulsatile versus nonpulsatile cardiopulmonary bypass flow: an evidence-based approach. Journal of cardiac surgery. 2006;21:347-54.

32. Alkan T, Akcevin A, Undar A, Turkoglu H, Paker T, Aytac A. Benefits of pulsatile perfusion on vital organ recovery during and after pediatric open heart surgery. Asaio J. 2007;53:651-4.

33. Hickey PR, Buckley MJ, Philbin DM. Pulsatile and nonpulsatile cardiopulmonary bypass: review of a counterproductive controversy. Ann Thorac Surg. 1983;36:720-37.

34. Mulholland JW, Shelton JC, Luo XY. Blood flow and damage by the roller pumps during cardiopul monary bypass. J Fluid Struct. 2005;20:129-40.

35. Murkin JM. Pulsatile versus nonpulsatile perfusion revisited. Journal of cardiac surgery. 2006;21:355-6. 
36. Taylor KM, Bain WH, Davidson KG, Turner MA. Comparative clinical study of pulsatile and non-pulsatile perfusion in 350 consecutive patients. Thorax. 1982;37:324-30.

37. Thompson T, Minami K, Dramburg W, Vyska K, Koerfer R. The influence of pulsatile and nonpulsatile extracorporeal circulation on fluid retention following coronary artery bypass grafting. Perfusion. 1992;7:201-11.

38. Simons AP, Wortel P, van Kan RAT, van der Veen FH, Weerwind PW, Maessen JG. Pulse conductance and flow induced hemolysis during pulsatile perfusion. Artif Organs. 2010;in press.

39. Herreros J, Berjano EJ, Sales-Nebot L, Mas P, Calvo I, Mastrobuoni S, Merce S. A new method of providing pulsatile flow in a centrifugal pump: assessment of pulsatility using a mock circulatory system. Artif Organs. 2008;32:490-4.

40. Undar A, Ji B, Lukic B, Zapanta CM, Kunselman AR, Reibson JD, Weiss WJ, Rosenberg G, Myers JL. Quantification of perfusion modes in terms of surplus hemodynamic energy levels in a simulated pediatric CPB model. Asaio J. 2006;52:712-7.

41. Bachus L, Custodio A. Know and understand centrifugal pumps. Oxford: Elsevier 2003.

42. Ganushchak Y, van Marken Lichtenbelt W, van der Nagel T, de Jong DS. Hydrodynamic performance and heat generation by centrifugal pumps. Perfusion. 2006;21:373-9.

43. Blomquist S, Gustafsson V, Manolopoulos T, Pierre L. Clinical experience with a novel endotoxin adsorbtion device in patients undergoing cardiac surgery. Perfusion. 2009;24:13-7.

44. Kulabukhov VV. Use of an endotoxin adsorber in the treatment of severe abdominal sepsis. Acta anaesthesiologica Scandinavica. 2008;52:1024-5.

45. Tetta C, Gianotti L, Cavaillon JM, Wratten ML, Fini M, Braga M, Bisagni P, Giavaresi G, Bolzani R, Giardino R. Coupled plasma filtration-adsorption in a rabbit model of endotoxic shock. Critical care medicine. 2000;28:1526-33. 

SUMMARY 
Extracorporeal life support (ELS) systems provide mechanical cardiopulmonary assistance by relieving the heart from hemodynamic load while organ perfusion is maintained. With veno-arterial ELS, intravascular volume is directly drawn from the venous circulation, typically by a centrifugal blood pump which then pumps the blood through an artificial lung into the arterial system. Today, ELS is used in a wide field of applications, such as (postcardiotomy) heart failure, percutaneous interventions, and respiratory failure.

The physical interaction between the ELS system and patient circulation in relation to the venous intravascular volume is studied in Chapter 2. The chapter provides a rationale for a new method, using pump speed manipulations to detect and reverse venous collapse resulting from low circulatory filling.

Venous drainage starts at the tip of the venous cannula. Chapter 3 investigates tip designs of five different cannulae used for central venous cannulation. When intravascular volume becomes critically low and the cannula inlet holes become obstructed, a cannula featuring a grooved and swirled tip shows slightly better drainage performance. In contrast, the study found no difference in performance between the various cannula designs when intravascular volume is sufficient.

In patients supported by a minimized extracorporeal bypass system, intravascular volume can be assessed using the dynamic filling index (DFI). Chapter 4 shows proof of principle of DFI measurement in patients undergoing coronary artery bypass grafting. The index proved more sensitive to small changes in intravascular drainable volume than routinely recorded parameters, which suggests good potential for the DFI to monitor 'on pump' venous return.

A pump control combining DFI measurement and pump speed adjustment results in a reserve-driven flow control scheme. Chapter 5 illustrates the action of such a reserve-driven pump control applied to ELS in an experimental setting, in which DFI measurement continually assesses drainable venous intravascular volume and pump speed is adjusted if drainable volume is below a certain threshold, enabling maximum level of support despite low filling conditions.

The use of the DFI to assess venous volume may be used to detect changes in cardiac pump reserve capacity when weaning from ELS. Chapter 6 presents a case report of a patient supported by ELS and in which DFI measurements were performed regularly. During attempts of weaning (i.e. decrease in bypass flow and thereby reloading the heart), the DFI confirmed findings on cardiac pump function found by transesophageal echocardiography and standard blood pressure monitoring.

Finally, Chapter 7 presents a Letter to the Editor of the journal 'Artificial Organs'. The letter discusses an ELS circuit using a new pulsatile centrifugal pump presented by Herreros et al. (abstract and figures in Appendix). In addition, response of the Spanish group is given as well. 
This thesis provides a first step in the development towards an ELS system which is able to match mechanical cardiopulmonary support to the patient's cardiovascular system. The results of the studies presented here are helpful to understand the interaction between the extracorporeal circuit and the patient's vascular system. An in-depth understanding of the interaction is crucial to optimize cardiopulmonary support. 

SAMENVATTING 
Extracorporale life support (ELS) systemen leveren mechanische cardiopulmonale ondersteuning door het hart hemodynamisch te ontlasten terwijl orgaanperfusie behouden blijft. Bij veno-arteriële ELS wordt intravasculaire volume direct uit het veneuze vaatbed genomen, veelal door een centrifugale bloedpomp welke vervolgens het bloed door een kunstlong naar het arteriële vaatsysteem pompt. Tegenwoordig kent ELS een breed toepassingsspectrum, waaronder gebruik bij (postcardiotomie-)hartfalen, bij percutane interventies en bij longfalen.

De fysische interactie tussen het ELS systeem en het veneuze intravasculaire volume van de patiënt wordt bestudeerd in Hoofdstuk 2. Dit levert een rationale voor een nieuwe methode welke gebruik maakt van manipulaties van de pompsnelheid om veneuze collaps ten gevolge van lage circulatoire vulling te detecteren en ongedaan te maken.

De veneuze drainage begint bij de inlaatopening van de veneuze canule. Hoofdstuk 3 onderzoekt verschillende ontwerpen van canules welke gebruikt worden voor centraalveneuze canulatie. Wanneer het intravasculaire volume kritisch laag wordt en de inlaatopeningen van de canule geobstrueerd raken, toont een canule met gedraaide groeven in de punt een betere drainagecapaciteit. In tegenstelling tot de situatie van extreem lage vulling, kon de studie geen verschil aantonen in drainage capaciteit tussen de verschillende canule-ontwerpen wanneer het intravasculaire volume toereikend is.

Hoofdstuk 4 introduceert de dynamische vullingsindex (dynamic filling index, DFI), waarmee het intravasculaire volume kan worden bepaald bij patiënten die worden behandeld met ELS. Het hoofdstuk toont het werkingsprincipe aan in patiënten tijdens coronaire bypass chirurgie. De index bleek gevoeliger voor kleine veranderingen van het intravasculaire draineerbare volume dan klassieke parameters, hetgeen suggereert dat de DFI beter in staat is om veneuze drainage te meten en te observeren.

Een pompregeling welke DFI metingen combineert met aanpassing van de pompsnelheid resulteert in een aanbodgestuurde debiet-regeling. Hoofdstuk 5 toont de werking van een dergelijke aanbodgestuurde debiet-regeling, toegepast in een experimentele ELS opstelling waarin DFI metingen continu het draineerbare veneuze intravasculaire volume bepalen en waarbij de pompsnelheid wordt aangepast wanneer het draineerbare volume onder een grenswaarde geraakt. Zo is het mogelijk om ook bij lage vulling de maximaal beschikbare ondersteuning te leveren.

Het gebruik van de DFI om het draineerbare veneuze volume te bepalen kan toepassing vinden om veranderingen in cardiale pompreserve te detecteren tijdens weanen van ELS. Hoofdstuk 6 presenteert een casus van een ELS-patiënt bij wie regelmatig DFI's werden bepaald. Gedurende pogingen de patiënt te weanen (afname in bypass debiet waarbij als gevolg het hart wordt belast) bevestigde de 
DFI bevindingen van cardiale pompfunctie zoals gevonden door transoesophageale echocardiografie en standaard bloeddrukmetingen.

Tot slot presenteert Hoofdstuk 7 een communiqué aan de redacteur van het blad 'Artificial Organs'. De brief bediscussieert een ELS circuit dat gebruik maakt van een pulsatiele centrifugale pomp zoals gepresenteerd door de groep van Herreros. Ook is de reactie van deze Spaanse groep opgenomen.

Deze dissertatie levert een eerste stap in de ontwikkeling naar een ELS systeem dat in staat is mechanische cardiopulmonale ondersteuning aan te passen aan het cardiovasculaire systeem van de patiënt. De resultaten van de studies welke hier zijn gepresenteerd zijn dienstig om de interactie tussen het extracorporele circuit en het vasculaire systeem van de patiënt te begrijpen. Een diepgaand begrip van deze interactie is cruciaal voor het optimaliseren van cardiopulmonale ondersteuning. 

ZUSAMMENFASSUNG 
Extrakorporale Kreislaufunterstützungssysteme (extracorporeal life support, ELS) bieten mechanische kardiopulmonale Unterstützung, indem sie das Herz entlasten und die Organsperfusion gewährleisten. Bei veno-arterieller ELS wird intravaskulares Blutvolumen direkt aus dem venösen Kreislauf genommen und durch eine Kunstlunge in den arteriellen Kreislauf pumpt. Dies geschieht vielfach durch eine Zentrifugalpumpe. Heutzutage findet ELS Anwendung bei unter anderem (postkardiotomie) Herzversagen, perkutanen Eingriffen und akutem Lungenversagen.

Die physikalische und hämodynamische Wechselwirkung zwischen dem ELSSystem und dem Patientenkreislauf in Bezug auf das venöse intravaskulare Volumen wird in Kapitel 2 untersucht. Hierbei wird das Gleichgewicht zwischen Volumenangebot und Volumenbedarf herausgearbeitet. Das Kapitel liefert das Grundprinzip einer neuen Methode, das Manipulationen der Pumpendrehzahl verwendet, um ein Kollabieren der venösen Gefässe aufgrund niedrigen Füllvolumens zu erkennen und zu beheben.

Die venöse Drainage beginnt bei den Einlassöffnungen der venösen Kanüle. Kapitel 3 untersucht Konstruktionen von Einlassöffnungen von fünf verschiedenen Kanülen welche bei der zentralvenösen Kanülierung Verwendung finden. Wenn bei kritisch niedrigem Füllvolumen die Kanüleneinlassöffnungen blockiert werden, zeigt eine Kanülenkonstruktion mit verdrehten Gruben an der Spitze einen leicht besseren Drainagefluss. Bei ausreichendem Füllvolumen zeigte die Studie jedoch keinen Leistungsunterscheid zwischen den unterschiedlichen Kanülenkonstruktionen.

Bei Patienten, die mit einem minimalisierten extrakorporalen Bypasssystem unterstützt werden, kann mittels des dynamischen Füllungsindex (dynamic filling index, DFI) das intravaskulare Volumen abgeschätzt werden. Kapitel 4 zeigt das Wirkungsprinzip von DFI-Messungen an Patienten welche eine koronare Bypassoperation untergehen. Hier bewies sich der Index als genaueres Mass für kleine Änderungen des intravaskularen drainierbaren Volumens als routinemäßig aufgezeichnete Parameter. Das suggeriert, dass sich DFI eignet um den venösen Rückfluss bei ,on pump' Anwendungen zu überwachen.

Eine Pumpenregelung, die DFI Messungen mit automatischer Anpassung der Pumpendrehzahl kombiniert, ergibt eine volumenangebot-gesteuerten Pumpenregelung. Kapitel 5 zeigt eine derartige Pumpenflussregelung und ihre Wirkung in einer experimentellen ELS-Anwendung. Hierbei werden zur Überwachung des drainierbaren venösen intravaskularen Volumens DFI Messung angewendet. Die Pumpendrehzahl wird angepasst, wenn das drainierbare Volumen unterhalb eines Schwellenwertes gerät. So ist es möglich auch bei niedrigem Füllvolumen den maximal zur Verfügung stehenden Pumpenfluss zu gewährleisten.

Die Verwendung des DFI als Instrument um das venöse Volumen zu abzuschätzen kann womöglich auch verwendet werden um beim Entwöhnung vom ELS Verän- 
derungen der kardialen Pumpreservekapazität zu erkennen. Kapitel 6 zeigt ein Fallbericht von einem ELS-Patienten bei dem regelmäßig DFI-Messungen durchgeführt wurden. Bei Entwöhnungsversuche (d.h. Abnahme des Bypassflusses und somit eine Wiederbelastung des Herzens) konnte der DFI die Befunde kardialer Pumpfunktion, die durch transösophageale Echokardiographie und standard Blutdruckmessung gefunden waren bestätigen.

Zum Schluss zeigt Kapitel 7 ein Kommuniqué an den Editor der Zeitschrift ,Artificial Organs'. Der Brief diskutiert einen ELS-Kreislauf unter Verwendung einer neuen pulsatilen Zentrifugalpumpe, die von der Gruppe von der Herreros vorgestellt wurde (Zusammenfassung und Abbildungen im Anhang). Darüber hinaus ist auch die Antwort der spanischen Gruppe gegeben.

Diese Arbeit stellt ein erster Schritt in der Entwicklung zu einem ELS-System dar, das mechanische Kardiopulmonale Unterstützung an das Kardiovaskulare System des Patienten anpassen kann. Die Ergebnisse der hier vorgelegten Studien mögen hilfreich sein, um die Interaktion zwischen dem extrakorporalen Kreislauf und dem vaskularen System des Patienten zu verstehen. Ein tiefgreifendes Verständnis dieser Interaktion ist zur Optimalisierung der Kardiopulmonalen Unterstützung unerlässlich. 

SOMMAIRE 
Les Systèmes extracorporal life support (ELS) livrent une assistance mécanique cardio-pulmonaire en soulageant le cœur de manière hémodynamique et en soutenant la perfusion des organes. ELS en situation veino-artériel prends le volume nécessaire directement du système veineux pour être pompé à travers l'oxygénateur vers le système artérielle. ELS se voit appliqué dans un large spectre de pathologies, défaillance cardiaque (post cardiotomie), interventions en défaillance pulmonaire.

L'Interaction physique entre le système ELS et le volume intra vasculaire veineux du patient, est étudié en Chapitre 2. Cela nous livre une rationnelle pour une nouvelle méthode qui va manipuler les variations de la vitesse de la pompe à fin de détecter et de corriger de manière intelligente un collapse veineux suite au remplissage circulatoire insuffisante.

Le drainage veineux est affecté par l'ouverture d'entrée de la canule veineuse. Chapitre 3 recherche la différence entre les concepts de canules, utilisés pour la canulation centrale veineuse. Au moment précis où le volume intra vasculaire atteint un niveau extrêmement critique avec une obstruction de l'ouverture d'entrée de la canule, nous constatons que les canules avec un concept au rainures torsadées permettent une capacité de drainage meilleure. Contrairement à la situation critique, où le volume de remplissage était extrêmement basse, l'étude n'a pas pu démontrer des différences parmi les concepts des canules quand le volume de drainage était suffisant.

Chapitre 4 introduit l'indexe de remplissage dynamique (dynamic filling index, DFI) permettant de déterminer le volume intra vasculaire chez les patients en traitement ELS. Le chapitre démontre le principe de fonctionnement chez les patients subissant une chirurgie de pontage aortocoronarien. L'index se montre plus sensible au changements très minimes du volume de drainage du systémique intra vasculaire, ce qui suggère que le DFI est un meilleur paramètre d'observation dans la mesure du drainage veineux.

Un système de régulation de la pompe qui combine le DFI et la vitesse de rotation de la pompe ayant comme résultat la régulation de débit en fonction du volume de drainage. Chapitre 5 montre le fonctionnement d'un système de régulation de débit en fonction du volume de drainage, appliqué au ELS en position expérimentale en mesurant en continu le DFI et en paramétrant le volume de drainage intra vasculaire disponible et en adaptant la vitesse de la pompe quand la limite du volume de drainage est atteinte. Ainsi, il devient possible d'offrir une assistance maximale avec un volume de drainage très bas.

L'Utilisation du DFI pour déterminer le volume de drainage peut trouver son application dans la détection de changements de réserve de la fonction cardiaque du patient pendant la sortie de pompe, sevrage du ELS. Chapitre 6 présente le cas d'un patient ELS sur lequel nous avons, de manière régulière, déterminé le DFI. Pendant les tentatives de sevrage du système ELS (diminution graduelle du débit 
de pompe avec comme but la reprise de la fonction cardiaque propre au patient luimême), le DFI confirmait les observations de la fonction cardiaque comme confirmé par les observations de l'échographie transoesophagienne et la prise de tension artérielle conventionnelle.

Pour terminer, le chapitre 7 présente un communiqué au rédacteur du journal 'Artificial Organs'. La lettre amène la discussion sur l'utilisation d'une pompe centrifuge en mode pulsatile dans un circuit ELS, étude présentée par le groupe de Herreros (synthèse et images en annexe). La réaction du groupe espagnole est également décrite.

Cette dissertation fournit un premier pas dans le développement d'un système ELS qui serait capable d'adapter l'assistance cardio-pulmonaire mécanique au système cardiovasculaire du patient. Les résultats de ces études présentés ici, nous servent à comprendre l'interaction du circuit extracorporelle et le système cardiovasculaire du patient. La compréhension profonde de cette interaction est cruciale pour l'optimalisation du support cardio-pulmonaire. 

DANKWOORD, ACKNOWLEDGMENT, DANKSAGUNG 
Jos, bedankt dat je dit promotieonderzoek mogelijk hebt gemaakt. Zo kon ik niet alleen mijn wens om wetenschapper te worden in vervulling laten gaan, maar me ook nog enkele jaren student voelen. Bedankt voor je vertrouwen! Trouwens, heb je nog leuke (bak)recepten?

Koen, als mijn directe begeleider en meest gevreesde criticus ben ik je zeer dankbaar. Dan wanneer ik het onderzoek even niet zag zitten wist jij precies weer de juiste stimulus te vinden om me ervan te overtuigen resultaten nogmaals te bekijken en er iets leuks van te maken. Iedereen zou minstens één copromotor als jij moeten hebben. Maar dat wat toch het meest boekdelen spreekt is de balkon-scene aan dat zwembad in Ann Arbor? Volgens mij heb je nu een glimlach op je gezicht!

Patrick (Weerwind), atraves di bo enthousíasmo í bista clinico riba mi pensamentunan, mi propio enthousíasmo a krese pa investigacíon relatá ku perfusion. Igualmente, sín bo presensia na e senanan riba dialuna anochi den cafetaria, nó era, lo no tabata agradabel í productivo. Danki pa bo disponibilidad 24 hora pa dia. Abo semper tabatin un kontestá riba mi preguntanan í solucioná kualke problema, si no cambia robes o drechi. Weerwind, bo ta un tipo unico! Un maravilloso copromotor í gran collegá. Masha danki!

Marcus, danke danke danke! Zum einen dafür stets deutsch mit Dir sprechen (und labern) zu können, zum anderen für das Miteinbringen Deiner klinischen Kenntnisse in unsere Studien. Des weiteren waren die spontanen Diskussionszwischenstops bei Dir im Büro im 4. Stock doch immer wieder lustig. Ich kann mich noch gut Deine Begeisterung erinnern als Ihr eine neue Kaffeemaschine bekommen hattet! Danke dafür, dass Du mein ,Paranimf' sein möchtest. Hierzu die meiner Meinung nach beste eMail aller Zeiten: „Paranimf? Was soll ich denn da machen?“. „Rumstehen, Marcus“. „Ach, dumm gucken kann ich gut. Ist gebongt!“. Überigens, mögen Deine Garnälen in der Küche gross werden! Mahlzeit!

Ervin, 'who cares?' Hvala ti na potpunom razumijevanju, tvoju potporu, puno, puno specijalnih i nezaboravnih chasova poduke uz jako crveno vino. Hvala za tvoje prisustvo i izdashne, bezposhtedne savjete. Hvala ti... Uzdravlje.

Pia, bedankt voor je vertrouwen en je steun bij mijn onderzoek. Dank ook voor de mogelijkheden die je mij bood om 'mijn perfusie-ideeën' te toetsen op perfusionisten uit binnen- en buitenland. Ook dank daarvoor dat je mij in staat stelde mening congres te bezoeken. Wolfgang, jou bedankt voor de vele én veilige (high-performance) take-offs and landingen. Chocolade is altijd goed hè?

Patrick (Blyau), zonder onze 'DSL-verbinding' zouden onze vele gesprekken tot laat in de nacht hebben geduurd. Ook mét de 'DSL' duurden ze zelden korter dan een uur. Bedankt voor je vele feedback, kritiek, brainstorming sessions, idieeën, dozen caloriën, en koffie-met-slagroom-gezelligheden. En áls we dan ooit uitgepraat waren over onderzoek hadden we direct weer ons vaste 'andere' thema klaar: the brilliance of sound and music. Nothing beats an engineer! 
Pieter (Wortel). Je bent een gangmaker eerste klas en naast een nu oud-collega ook een goede vriend. Maar als ik hier nu net zoveel moest gaan schrijven als jij babbelt, dan begin ik beter aan een tweede boekje. Ik houd het daarom bewust kort: heel hartelijk dank voor de vele brainstorm sessies, ideeën, feedback, gezellige biertjes, hapjes en custom-made pannenkoeken! Verder wens ik je natuurlijk heel veel succes met je verdere carrière!

(Fred)erik, altijd weer leuk en leerzaam om artikels en abstracts te bespreken. Dank voor jouw aandeel in de supervisie van mijn onderzoek. Heeft 't vandaag het personeelsrestaurant nasi? Trouwens, kun je je nog het bananenbier herinneren?

Kris (Crash), Wim (Wham), Rob(bert) en Jack (S-hak)... Thanks voor de vele uren en dagen samen op één kamer op de uni. Eerst keten op onze 'Dé Zes', naderhand 'serieus' (ehum) drie etages lager. Wat hadden we een lol samen! Als je alle op post-its genoteerde 'beruchte uitspraken' (nuttige en niet nuttige) van de afgelopen 4 jaar op een rij zet komen we op meer dan 3 meter boekenplank!! Rob, bedankt voor het steeds voorproeven van de cake (je leeft nog) en geweldige goed doordachte opmerkingen door de dagen heen. Ook aan Loes en Nard: gezellig, de biertjes, etentjes, congresbezoeken en niet te vergeten, het uitgaansleven. Heb er erg leuke herinneringen aan. Loes, als 'ervaren' promovenda ook nog bedankt voor het vaak wegwijs maken binnen de burocratie. Monique, Pol, dank voor de gezelligheid aan de 'overkant' en ondersteuning tijdens de onderzoekjes, zowel hier in Maastricht als in't buitenland. De keuken in Florence was écht lekker, he? Rogerke, ook jij bedankt, mede voor de gezelligheid tijdens de lunches.

Rob (van Kan,) Raoel, Erik Mooren, Erik Dortangs, Thomas, Matthijs, Jim (Space-Jim), Ellen en Stefan (Stief-man). "Kiek 'm goan, hoppa, plat op ziene ruk". Dank aan de vele super amusante uren welke we samen hebben doorgebracht, zij het op het lab, dan wel tijdens de lunches en vele koffiepauzes. Meestal meer gein dan serieus, maar altijd met een leuk resultaat. Sjnoepjes, hür! Ook Antoine en Christiaan, dank voor de lol :o).

An, Annerie, Sonia, Tine en de vele andere hier niet genoemde koffieleuten... bedankt voor de gezellige dagelijkse koffiepauzes bij de Douwe Egberts. Al eens teruggeteld hoevaak we daar gezeten hebben? Dames, we hebben een vermogen aan koffie verzopen... En niet te denken aan de bérgen slagroom! Kiló's zeg ik jullie!! En jummie, wat een uitzicht, toch, Adri? Gezellig!

Dank aan de perfusionisten en medewerkers van de extracorporale circulatie voor jullie aandeel in het onderzoek als ook de gezelligheid, de leuke gesprekken en vele kopjes koffie en hapjes\&borrels samen. Diana, Ellen, Ervin, Evelien, Ingrid, Jan, Joe, Marc, Naveen, Nicole, Nico, Roland, Vito, Yvonne, Zaheer, bedankt! Yuri, dank voor je superkritische opmerkingen (de vele 'one more question') met vaak nog kritischere blikken ('well, mhmm') waardoor ik het geheel toch nog eens van de andere kant ging bekijken. 
Dick, dankjewel voor je inbreng in en hulp bij het onderzoek in de eerste jaren van het promotieonderzoek. Het ga je goed, geniet van je pensioen.

Theo, ook jij bent onderhand met pensioen. De jaren die we hebben samengewerkt heb ik altijd als zeer plezierig ervaren. Bedankt voor het regelen en ritselen van vanalles. Jij kende iedereen en kon álles regelen! Bedankt man!

Dank aan de cardiothoraal chirurgen en assistenten van de afdeling MUMCCTC voor medewerking bij onderzoek op OK als ook bij het proeven van zelfgebakken cake. Bedankt!

Etiënne van den Heuvel en collegae van de instrumentele dienst, bedankt voor de technische ondersteuning op de OK waar nodig en leerrijke tekst en uitleg over wat bureaucraten nú weer voor normen en keurmerken verzonnen hebben. Richtlijnen, 'mer jonges nee!'. Maar je bent er altijd met de nodige humor naar blijven kijken en geeft nooit op!

Dank ook aan de afdelingen F3 (ICU) en D4 (verpleegafdeling) voor de werkgerelateerde en persoonlijke gesprekken, als ook voor het interesse. Dank voor het bewaren van 'Swan-Ganzen' voor onderzoek en de bereidheid mij over patiënten te informeren. Thx!

Den Mitarbeitern der Firma Maquet Cardiopulmonary AG in Hirrlingen und Hechingen möchte ich auf diesem Wege danken für die erhaltene technische Unterstützung, Führungen, Präsentationen, Diskussionen und nicht zuletzt, für gemütliches Zusammensein auf Kongressen und in der Firma.

Bij dezen ook dank aan het secretariaat, voor het regelen van vanálles, en natuurlijk voor de dagelijkse babbel en roddel (klinkt dit nu te cliché?). Lysette, Helma, Nicole, Sylvia, Anja en Luciënne, dankjulliewel. Ik zal spoedig weer wat lekkers voorbij brengen!

René Siemerink, bedankt voor de super keukenservice van jou en jouw team.

Monique Noordermeer en Brigitte Hendrieckx wil ik bedanken voor leuke gedachtenwisselingen en de gezellige bakjes koffie (mét slagroom, hè, Monique!?).

Annette Bel en Afke Pap, bedankt voor het uitwisselen van gedachten en een lekker hapje op zijn tijd in de stad, of een lekker bakkie slagroomkoffie.

Maarten Janssen-Duyghuysen, ook jou dank voor de nodige gesprekken in welke wij op een leuke manier van gedachten konden wisselen.

Yves Engelen. Het promotietraject is zonder problemen verlopen. Toch was het een geruststelling te weten dat jij als mentor op de achtergrond een oogje in het zeil hield.

Heel hartelijk wil ik een ieder bedanken die mij direct en indirect geholpen heeft bij de totstandkoming van dit boekje. Dank aan hen met wie ik interessante on- en non-topic discussies heb mogen voeren en gedurende het promotietraject lief en leed heb kunnen/moeten/mogen delen. Bij dezen ook mijn dank aan de patiënten 
zonder welke het klinische deel van mijn boekje niet mogelijk was geweest. Dank voor Uw vertrouwen!

Tot slot, pap, mam, dankjewel. 



\section{CURRICULUM VITAE}

Antoine was born in 1980 in Heerlen, the Netherlands. After finishing his elementary and secondary school in Landgraaf, the Netherlands (VWO, Eijkhagencollege), he moved to Germany for his technical education at the Aachen University of Applied Sciences, Campus Jülich. After his graduation as Dipl.-Ing. (FH) in 2002 on stentless heart valve testing, he proceeded with a Master in Cardiovascular Engineering which he finished in 2004 at the same department. Next, he moved to Maastricht to work as a PhD student on the extracorporeal life support project at the Maastricht University Medical Center, Dept. of Cardiothoracic Surgery. In the beginning of 2010 he started his education as a clinical perfusionist... 


\section{LIST OF PUBLICATIONS}

\section{Articles}

Simons AP, Reesink KD, Molegraaf GV, van der Nagel T, de Jong MMJ, Severdija $E E$, et al. An in vitro and in vivo study of the detection and reversal of venous collapse during extracorporeal life support. Artif Organs. 2007;31:152-9.

Simons AP, Ganushchak Y, Wortel P, van der Nagel T, van der Veen FH, de Jong DS, et al. Laboratory performance testing of venous cannulae during inlet obstruction. Artif Organs. 2008;32:566-71.

Simons AP, Reesink KD, Lance MD, van der Veen FH, de Jong DS, Weerwind PW, et al. Dynamic filling index: a novel parameter to monitor circulatory filling during minimized extracorporeal bypass. Eur J Cardiothorac Surg. 2009;36:330-4.

Simons AP, Wortel P, van Kan RAT, van der Veen FH, Weerwind PW, Maessen JG. Pulse conductance and flow induced hemolysis during pulsatile perfusion. Artif Organs. 2010;in press.

Simons AP, Reesink KD, Lance MD, van der Veen FH, Weerwind PW, Maessen JG. Reserve-driven flow control for extracorporeal life support: proof of principle. Perfusion. 2010;25:25-9.

Simons AP, Lance MD, Reesink KD, van der Veen FH, Weerwind PW, Maessen JG. Pumpenflussregelung mit dynamischer Vorlastmessung für die extrakorporale kardiopulmonale Unterstützung - ein Lösungsansatz? Kardiotechnik. 2010; in press.

Simons AP, Lancé MD, Reesink KD, van der Veen FH, Weerwind PW, Maessen JG. Quantitative assessment of cardiac load-responsiveness during extracorporeal life support: case and rationale. J Cardiothorac Surg. 2010;5:30-33.

\section{Letters}

Simons AP. June 2008 issue: Jesus Herreros from the University Hospital of Navarra, Pamplona, Spain. Letter to the editor. Artif Organs. 2008;32:1000-1; author reply $1-2$.

Simons AP, Groenenberg I, Ganushchak YM, Weerwind PW. "Water leakage" in an oxygenator; A suspected unexpected phenomenon. Perfusion. 2010;in press. 


\section{Abstracts}

Simons AP, Reesink KD, Molegraaf GV, van der Nagel T, de Jong, MM, Severdija EE, de Jong DS, van der Veen FH, Maessen JG. Detection and reversal of venous collapse during extracorporeal life support. Poster presentation at the $14^{\text {th }}$ Congress of the International Society of Rotary Blood Pumps, held August 31-September 2, 2006 in Leuven, Belgium. Artif Organs. 2006;30:A39.

Simons AP, Ganushchak YM, Wortel P, van der Nagel T, van der Veen FH, Maessen JG. Performance of venous cannulae during inlet obstruction. Oral presentation at the bi-Annual Meeting of the Netherlands Association of Cardiothoracic Surgery, held April 26-27, 2007 in Amsterdam, the Netherlands.

Simons AP, Ganushchak YM, Wortel P, van der Nagel T, van der Veen FH, de Jong DS, Maessen JG. Performance of venous cannulae for proximal cannulation during collapse of the drainage site: an in vitro study. Oral presentation at the $12^{\text {th }}$ European Congress on Extracorporeal Circulation Technology, held June 6-9, 2007 in Kiev, Ukraine. Proceedings of the $12^{\text {th }}$ European Congres on Extracorporeal Circulation Technology. ISBN 978-90-8559-534-2.

Simons AP, Reesink KD, Lancé MD, van der Nagel T, van der Veen FH, de Jong DS, Weerwind PW, Maessen JG. Dynamic filling index: a method to monitor circulatory filling during extracorporeal bypass. Poster presentation at the $13^{\text {th }}$ Annual Update on Cardiopulmonary Bypass, held March 9-14, 2008 in Whistler, BC, Canada.

Simons AP, Reesink KD, Lancé MD, van der Veen FH, Weerwind PW, Maessen JG Dynamic filling index: a novel method to monitor circulatory filling during extracorporeal bypass. Oral presentation at the bi-Annual Meeting of the Netherlands Association of Cardiothoracic Surgery, held May 23, 2008 in Utrecht, the Netherlands.

Simons AP, Reesink KD, Lancé MD, van der Nagel T, van der Veen FH, de Jong DS, Weerwind PW, Maessen JG. Dynamic filling index: a novel parameter to monitor circulatory filling during minimized extracorporeal bypass. Oral presentation at the 8th Conference on Perfusion Education and Training, held September 13, 2008 in Lisbon, Portugal. 
Simons AP, Reesink KD, Lancé MD, van der Nagel T, van der Veen FH, Weerwind PW, Maessen JG. Reserve-driven flow control for extracorporeal life support: proof of principle. Oral presentation at the $38^{\text {th }}$ International Meeting on Perfusion of the German Society for Cardiovascular Engineering, held November 6-8, 2009 in Weimar, Germany. Kardiotechnik. 2009;Suppl1:25.

Simons AP, Wortel P, van Kan RAT, van der Veen FH, Weerwind PW, Maessen JG. Pulse conductance and flow-induced hemolysis during pulsatile cardiopulmonary bypass. Oral presentation at the Scientific Autumn Meeting of the Netherlands Society of Extracorporeal Circulation, held November 28, 2009 in Ermelo, the Netherlands.

Simons AP, Wortel P, van Kan RAT, van der Veen FH, Weerwind PW, Maessen JG. Pulse conductance and hemolysis during cardiopulmonary bypass. Oral presentation at the $31^{\text {st }}$ Annual Seminar on Cardiovascular Perfusion of the American Academy of Cardiovascular Perfusion, held January 28 - February 31, 2010 in Nashville, TN, United States of America.

\section{Awards}

Most original paper award, at the 12 $12^{\text {th }}$ European Congress on Extracorporeal Circulation Technology - FECECT, held June 6-9, 2007 in Kiev, Ukraine.

Lawrence Scientific Presentation Award, at the 31 $1^{\text {st }}$ Annual Seminar on Cardiovascular Perfusion of the American Academy of Cardiovascular Perfusion - AACP, held January 28 - February 31, 2010 in Nashville, TN, United States of America.

\section{Patents}

PCT / EP2008 / 000927 Verfahren und Vorrichtung zur Überwachung und Optimierung eines durch eine Pumpe bewirkten Kreislaufes (Method and apparatus for monitoring and optimizing blood circulation generated by a pump). 